LIBRI

www.libridergi.org

Kitap Tanıtımı, Eleștiri ve Çeviri Dergisi

Journal of Book Notices, Reviews and Translations

Volume II (2016)

S. REDFORD, "Intercession and Succession, Enlightenment and Reflection: The Inscriptional Program of the Karatay Madrasa, Konya". Ed. A. Eastmond, Viewing Inscriptions in the Late Antique and Medieval World. Cambridge (2015) 148-169. Cambridge University Press, 275 Pages (73 Illustrations). ISBN: 9781107092419

\section{T. M. P. DUGGAN}

The entire contents of this journal, Libri: Journal of Book Notices, Reviews and Translations, is open to users and it is an 'open access' journal. Users are able to read the full texts, to download, to copy, print and distribute without obtaining the permission of the editor and author(s). However, all references to the book notices, criticisms and translations published in the e-journal Libri are to indicate through reference the source of the citation from this journal.

Libri is an international peer-reviewed journal and the book notices, criticisms and translations which have had their peer reviewing process completed will be published on the web-site (www.libridergi.org) in the year of the journal's issue (e.g. Volume II: January-December 2016). At the end of December 2016 the year's issue is completed and Volume III: January-December 2017 will begin.

Responsibility for the book notices, criticism and translations published in this journal remains with the authors.

Citation T. M. P. Duggan, "Intercession and Succession, Enlightenment and Reflection: The Inscriptional Program of the Karatay Madrasa, Konya". By S. Redford. Libri II (2016) 1-62. DOI: 10.20480/lbr.2016001

Received Date: 14.01.2016 | Acceptance Date: 07.02.2016 | Online Publication Date: 14.02.2016 URL: http://dx.doi.org/10.20480/lbr.2016001

Editing Phaselis Project

www.phaselis.org 


\title{
S. REDFORD, "Intercession and Succession, Enlightenment and Reflection: The Inscriptional Program of the Karatay Madrasa, Konya". Ed. A. Eastmond, Viewing Inscriptions in the Late Antique and Medieval World. Cambridge (2015) 148-169. Cambridge University Press, 275 Pages (73 Illustrations). ISBN: 9781107092419
}

T. M. P. DUGGAN*

The author of this chapter entitled: 'Intercession and Succession, Enlightenment and Reflection: The Inscriptional Program of the Karatay Madrasa, Konya', and the present Nasser D. Khalili Professor of Islamic Art and Archaeology at SOAS, University of London, writes concerning the interpretation of works of Islamic art and architecture, the subject he professes:

\begin{abstract}
"A cottage industry of writers and publishers has regularly imparted religious, especially mystical, meaning to works of Islamic art and architecture. The subject of mystical interpretation of a work of Islamic architecture, therefore, is a sensitive one, not only because it is hard to prove but also because maintaining that artistic traditions exist mainly to embody eternal religious verities opens one up to the charge of cultural essentialism"1
\end{abstract}

The first sentence of this passage is by both definition and logic, a non-sense. Works of "Islamic art and architecture" by definition as such, carry a religious meaning and context, being described with the term Islamic, and consequently writers and publisher who give "religious, especially mystical, meaning to works of Islamic art and architecture.", are necessarily not themselves therefore imparting a religious or mystical meaning(s) to these works of Islamic art and architecture, but perhaps simply recognising as the term Islamic art indicates, that which is present, the meanings, religious or mystical, being explicit or implicit in these works and it is surely the work of an art historian to address meaning as well as measurable form.

It is of course the presence of religious and mystical references and context which enables these works of art and architecture to be identified as Islamic and it has been the religion in all its variations and interpretations over time which has provided the context and the reason for the making by means of art those structures and objects that are so described. Islamic art and architecture is recognisably different from Christian, Hindu or Buddhist art and architecture. At the most basic level of discrimination, disregarding differences in the identifying terms, a mosque remains recognisably different from a Christian church, a Jewish synagogue, a Hindu temple or a Buddhist wat, and the reason for these different forms and types of structure and

\footnotetext{
* Lecturer, Akdeniz University, Mediterranean Civilisations Research Institute (MCRI), Antalya. tmpduggan@yahoo.com

1 Redford 2015, 165.
} 
the reasons for the forms and types of embellishment given to these structures, is a consequence, not primarily of differences in climate and available construction materials, but because these different religions have different requirements for the practice of worship, reasoned and different views regarding where the emphasis in the practice of making of a structure or object should be placed, and consequently, different forms have been developed to express perspectives that the religion provides and these have been deemed appropriate to their function and repeated over time with variations around the core requirements, forming recognisable traditions in art and architecture.

The author goes on to warn the reader that, "maintaining that artistic traditions exist mainly to embody eternal religious verities opens one up to the charge of cultural essentialism." Oh dear me! No doubt about it, exposed to the cruel winds of post-modernist ideology, this is a truly frightening charge. It is however the case that artistic traditions, as distinct from the humanistic-hedonistic cult of individuality of expression, have existed mainly to embody, maintain, convey, articulate and remind of religious truths through their articulation in various forms, making their contribution to the individual's perception of the world, to culture in its varied forms, and to society. Submission to Islam, becoming Muslim entails belief in "eternal religious verities", as becoming or accepting Christianity, or any other religion likewise entails belief in "eternal religious verities", the articles of faith and long-lasting traditions, artistic or other, do rather tend to have a religious fundament that tends to colour the culture in its various aspects in the millennia prior to the advent of modernity. As Jālāl al-Dīn Rūmi remarked in the $13^{\text {th }}$ century, "So, when you investigate all trades (crafts), the root and origin of them was revelation, men have learned them from the prophets, and they are the Universal Intellect" ${ }^{2}$.

A problem of course for multiculturalists is that the term essentialism is derived from Plato and his concern with a thing's essence, those properties that distinguish a particular thing enabling it to be "re-cognised" and as such named, this being a matter of discrimination ${ }^{3}$, the bedrock of learning being the ability to recognise, to define and distinguish difference, as between things, and so to name them. Plato's concern with defining the essence of things was passed, through translation of the works of Plato via the Neo-Platonist ${ }^{4}$ philosophers into Islam ${ }^{5}$ and also to the Medieval Latin world. These included works by Plotinus (c.204/5-270) and by

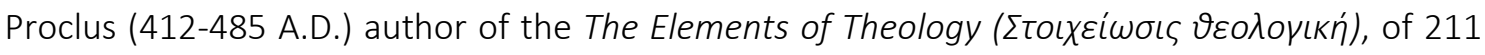
propositions and proofs, beginning from the existence of the One (divine Unity, as Being proceeds from the One. The One cannot itself be a being) and ending with the descent of individual souls into the material world, a work later thought to be by Aristotle and which was summarised in Arabic, being recognised as a statement of tawhild, meaning the oneness [of God] $]^{6}$, and this was then translated into Latin as the influential Liber de Causis (Book of Causes);

2 Jālāl al-Dīn Rūmī Fîhi Mâ Fîhi 38.

3 "When, however, a man has spent his life in the company of people (or of course today the media, social or otherwise), who lack discrimination, his own discriminative faculty becomes feeble and he is unable to recognise... Do you not see that a madman possesses hands and feet but lacks discrimination? Discrimination is that subtle essence within you". Jālāl al-Dīn Rūmī Fîhi Mâ Fîhi 2; "That discrimination is faith, and unbelief is lack of discrimination". Jālāl al-Dīn Rūmī Fîhi Mâ Fîhi 39.

4 The term Neo-Platonist being coined in the $19^{\text {th }} \mathrm{c}$. and a term unknown to those so described.

5 On this see for example see: Netton 1991; Morewedge 1992; Mahdi 2001.

6 That the One in essence cannot itself be a being, is recognised, termed as such, "Oneness of Essence - 


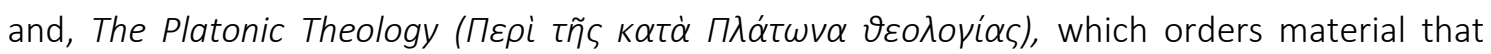
shows the characteristics of the divine orders, that part of the universe which is closest to the One, extracted from the Platonic dialogues. The charge concealed beneath the modern somewhat nonsensical term, cultural essentialism, being rather one of drawing attention to "eternal religious verities". The charge of religious essentialism, of "religio"- of tradition and its binding, rather than imbibing and regurgitating the modern conceits of political correctness and postmodernist relativism, etc., in the study of the evidence of past cultures.

If it was fear of the charge of "cultural essentialism" that resulted in the most unfortunate loss from this chapter of the text relating to the author's stated finding in his conclusion of correlation-analogies between the Neo-Platonic levels of meaning in Sufi thought and the levels of ornament and script in the domed courtyard of this madrasa ${ }^{7}$, is unknown to this reviewer, and the non-appearance of evidence of this correlation is much regretted.

The usual modern educational discipline's reductionist-divisive approach to the study of the remains of the past has had some most interesting consequences, not least in the way epigraphic material, if it is understood in its full extent, has been treated over the past 250 years. It has resulted at times for example in epigraphers isolating and abstracting the depicted letters of a text from the inscription's context on a building or object within its particular surroundings. Likewise, reading an antique or Medieval carved stone text stripped of its colour ${ }^{8}$, as though the colours originally employed on the "epigraphic material" as elsewhere, as in the designs employed within an architectural or other context, carried no meaning, these designs were just filling patterns employed like the colours of inscriptions, for so-called "aesthetic reasons". As if this modern term, 'aesthetic', newly coined in the French $18^{\text {th }}$ century so-called 'Enlightenment', had formed a central part of the mind-set and an acceptable rationale for the employment of colour, as likewise for design and pattern in the minds of Medieval designers and craftsmen, Muslim or Christian, as though colour, design and pattern were employed in some arbitrary unreasoning sensory manner expressing the capriciousness, the vagarities, of Medieval taste. There is of course no Medieval evidence to suggest colour, design and pattern were employed in any arbitrary unreasoning simply sensory manner by Christian or Islamic Medieval craftsmen-designers; nor is there evidence of the use of the word-term 'aesthetic' in Medieval texts.

Consequently, in particular in the case of Islamic works that are known through the status of the patron of the work or from documentary record to have been designed by nakkashdesigners - including works which were in terms of the overall design and the parts thereof, in all probability the product of the state nakkaşhane, the state/palace design studio - the employment of modern Western reductionism tends to rend a whole, the complete complex design of a work such as a building, a manuscript or other work, into separate parts and fragments, thereby making the understanding of the individual complete work rather more difficult, as the whole individual work, in consequence of the use of this approach, has been

Ahadiyyat al-'Ayn, or Ahadiyyat al-ahad" by Ibn 'Arabī, Addas 1993, 279. Ibn 'Arabī relates, "The world is nothing other than His epiphanisation in the form of the immutable essences which cannot exist without Him". Addas 1993, 283, Him being the One in essence that cannot itself be a being.

7 Redford 2015, 165.

8 Duggan 2016a. 
chopped up into separate often largely unrelated areas of study:

a) the object or building, with for example, its plan and elevation compared to other similar examples, and on occasion, the search for some "Ur" or "ancestor structure" stretching through the millennia from ancient Sumer and the Hittites through the Tien Shan to Timbuktu and beyond, in the hunt for the supposed origins of the type of structure somewhere-someplace in some hypothetical elusive year zero.

b) the epigraphy-epigraphic cycle employed, confined and compared to similar examples of script.

c) other subdivisions including particular details of the work, the ornament and patterns employed, the tile-work, mihrāp, minbar, plasterwork, column capitals, the re-use of ancient material as spolia, mason marks invisible until the surfacing has been lost from the building, etc.

Each area treated separately and related to its own particular typology. This, in the apparent attempt to understand some whole thing, through applying this divisive methodology to the object of study, to some part of the whole, yet the whole inevitably was and is something rather more than the sum of its individual parts.

The consequences of this reductionist thinking were clearly understood in the $13^{\text {th }}$ century, as is related in a teaching tale by the late $13^{\text {th }}-14^{\text {th }}$ century incomparable Mulla-Hoja Nasr edDin (more properly Nasir al-Dīn, meaning Defender of the Faith, i.e. Defender of Islam), concerning establishing the exact capacity of a newly discovered ancient valuable Chinese vase:

"An ancient and valuable fragile Chinese vase had been found by the villagers. There was an argument in the teahouse as to its exact capacity. During the wrangling, the Mulla entered. The people appealed to him for a ruling.

'Simple,' said Nasruddin. 'Bring the vase here, together with some sand.'

He had the vase filled with layer after layer of fine sand, packing it down with a mallet. Ultimately it burst.

'There you are,' - he turned to the company triumphantly - 'the maximum capacity has been reached. All you have to do now is to remove one grain of sand, and you will have the precise amount needed to fill a container like this'"'9.

The fragile ancient valuable Chinese vase was smashed into fragments so that the exact capacity of the vase as a container could be determined, the beauty of the whole destroyed in the search for an exact quantity, yet the exact capacity of the form was simply a part of a beautiful whole.

In a volume such as this, directly addressing through its title "Viewing Inscriptions in the Late Antique and Medieval World", one particular element, the inscription(s) on a building, structure or object, a volume which is said to provide, "A new and wide-ranging approach to the study of inscriptions, focusing on writing as material culture." ${ }^{10}$; it is perhaps noteworthy, if not entirely unsurprising, that Medieval Islamic patterns are not more fully addressed. Yet these need to be addressed because these patterns were themselves often designed to be "read as text" and are

9 Shah 1975, 184.

10 Source: http://www.medievalhistories.com/viewing-inscriptions-in-the-late-antique-and-medieval-world/ 
therefore in actuality also "inscriptions-epigraphic documents" in the etymological sense of the word 'epigraphy', comprising the study of signs, because a sign/vpaфn'/graphe, that is a lettercharacter or other shape, conveys meaning through both its shape and its colour, hence the word epigraphy in fact, literally means the study of coloured signs, a reality acknowledged or not by epigraphers today, forming a part of semiotics, because patterns, arrangements of signs, as with the letters of an alphabet or numbers, are signs, and so, perhaps patterns and colours should once again be "read" by those who today study such things, epigraphers- semioticians and art historians.

It seems obvious that in a society where literacy, the ability to read, to read and internalise the sacred text was prized, combined with the record of seeing in terms of words and letters, as for example is related in the following two $13^{\text {th }}$ century accounts of seeing in terms of letters: "Ibn 'Arabi saw the Divine Essence in the shape of a luminous (letter) he, carrying between its two arms the word huwa (He) on a radiant red background." ${ }^{11}$, and concerning the experience of this matter of the experience of letters and words by a Kubrāwiyya ${ }^{12}$ follower, Annemarie Schimmel wrote: "Permanent concentration on the divine names in the retreat leads to mystical awareness...In the state of elevation, the mystic may be able to read heavenly books in languages and characters previously unknown to him and learn the heavenly names of things and beings, including his own eternal name, which is different from his worldly name."13; as likewise a later Naqshbandi meditation on the physicality of letters, of walking round and between them in the heart and the spiritual imagination: "He sees the blessed figure of the word Alläh in the color of light written on the tablet of his heart and the mirror of his imagination... Then he will understand himself as opposite to this form or beneath it or at its right or left side, and he should strive to bring himself towards this light...And whenever he finds himself in the middle of the rank of alifand läm, he must proceed and take his place between the two lāms and then walk away from there and bring himself between the lām and the $h$; and with high ambition he leaves this place too and sees himself in the middle of the ringlet of the $h$. At the beginning he will find his head in this ringlet, but eventually he will find that his whole self has found repose in this house and will rest there free from all afflictions and perilous calamities." ${ }^{14}$; which, is combined with the repeated emphasis within the Holy text itself, that within this world there are signs that need to be recognised, read, understood and internalised, eg. Sūrat Ibaqarah, The Cow 2:151, "As We sent to you an Apostle from among yourselves, who recites to you Our signs, and purifies you, and teaches you the Book and wisdom, and teaches you what you did not know.", that is, the Holy Qur'an is itself a sign, which is itself composed of signs-ayet, as likewise, Sürat a al 'im'rān 108, "These are the signs of Allah which We recite to you in truth, and Allah does not desire any wrong for the creatures."; while the temporal universe is also structured with signs to be "read", as is related in Sürat āl 'im'rān 3:190 "Indeed in the creation of the heavens and the earth and the alternation of night and day, there are signs for those who possess intellects.", as likewise, Sūrat Al-Dhāriyāt, 51:20, "On earth and in yourselves there are signs for firm believers. Can you not see them?"15. Consequently the patterns-designs-signs-

11 Schimmel 1984, 99, emphasis added.

12 An Path-order founded by Shaikh Najm al-Dīn al-Kubrā (1145-1220).

13 Schimmel 1978, 255-256.

14 Schimmel 1984, 99, emphasis added.

15 "And in the earth are portents for those whose faith is sure. And (also) in yourselves. Can ye then not see?" 
letters/numbers-colours employed to cover the surface of an object, structure, textile or building were consciously and deliberately designed to carry/convey meaning, the patternsdesigns-signs which were employed were to be read as signs and were not meaningless space fillers - were not just decoration or ornamentation. Just because the sign can no longer be read and understood for what it says, doesn't mean it has ceased to be a sign and has become something else, decoration-ornament-pattern. It means we are no longer educated to identify and read the text in the language of signs employed.

The difference between the two forms of text, the explicit text recorded in script and the implicit text expressed through pattern, number, colour and design, including deliberate lacunae such as deliberate empty space and missing letters and words, resembling thereby that difference between As-Zahir - The Outward and Al-Bartin - The Inward.

It is the case that Medieval Islamic patterns can, and it seems they were, designed to be "read", echoing the signs placed on earth and in people by the Almighty for firm believers to read. It is the responsibility of the firm believer to look for, recognise and read these signs, signs which serve to confirm belief. The firm believer in Islam was and remains in this sense a

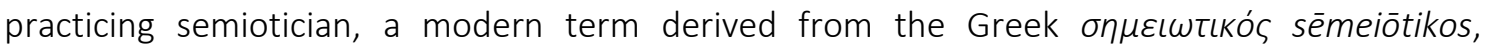
meaning, 'observant of signs'.

For example, the zigzag pattern which is found on numerous Seljuk structures and objects, as also on numerous other works of Islamic culture ${ }^{16}$, and which has been described by the author of the chapter reviewed here, as, "characteristic of Seljuk royal structures" ${ }^{17}$, can be "read" as text. This pattern consisting of both the number $v 7$ repeated, and the number 8 repeated $\wedge$, which, when both are joined together forming this repeat design-pattern, the numbers forming which, if added together give a sum of 15 , the digits of which $1+5$ when summed give the number $6^{18}$. Consequently one can read the zigzag pattern as a repeat of the number 6 . The number six is represented by the Arabic letter wā $w, 9$, and, noteworthy is that there are 114 Surrat/chapters in the Holy Koran, and 1+1+4=6 = the letter wav, meaning, 'and', and implicitly in the $12^{\text {th }}$ and $13^{\text {th }}$ centuries, the Arabic letter wā w was "read" in a religious context as implying-meaning, "and (Alläh)", as was related by figures such as Sheikh Najm al-Dīn Kubrā (1145-1220), this letter being understood as being, "the letter of connection between man and God" ${ }^{19}$, linking the Muslim with the Almighty, with the letter 'wāw/and', explicitly or implicitly meaning 'and Allāh', while a pair of wāw letters, 66, forms the numerical equivalent of the sum of the letters forming the Name Allāh. Further, there is the traditional understanding that the Holy Qur'an comprises 6,666 Ayet which can be represented by the letter wāw repeated 4 times, that is the letter mirrored on both a vertical and a horizontal axis. Consequently the zigzag pattern itself, rather than being just ornament, meaningless decoration, a pattern filling up or marking a space etc., is rather a text consisting of a sequence of signs forming a pattern to be read, internalised and understood, the zigzag pattern can be

\footnotetext{
Holy Qur'an Sūrat Al-Dhāriyāt 20-21 (Trans.: Picthall 1998).

16 Duggan 2016b.

17 Redford 1996, 454.

18 For further on the practice of "reading" of the alphanumeric script in the $13^{\text {th }}$ century see for example: Yakıt 1992; er-Ravendi 411-420; Ibn Arabi 2000.

19 Schimmel 1984, 100
} 
'read' by the literate as zikrullah, repeating and reminding implicitly of the Name of the Almighty, and today deciphered and read by the epigrapher. That is, Islamic pattern designed and employed in the past over a wide range of surfaces form epigraphic documents and, consequently, pattern can be a text that needs to be read by those studying the inscriptions of a building, structure or object.

It seems probable, although by no means certain, that with the decline of the state nakkashhane - palace design studios in the Islamic world, the relationship between the explicit and the implicit expressions of text applied to an object, structure or building inevitably declined and, by the time serious academic attention began to be paid to this evidence in the $19^{\text {th }}$ and $20^{\text {th }}$ centuries, it had already been divided into two almost entirely separate areas of study. There is the on-going study of the explicit text recorded in inscriptions in a wide variety of materials and surfaces, studied by specialists including epigraphers, with their own scholarly publications, including the volumes and scholarly apparatus of the MCIA (Matériaux pour un Corpus Inscriprorum Arabicarum) and the RCEA (Répertoire chronologique d'épigraphie arabe), both series beginning in the first half of the $20^{\text {th }}$ century. Then there is the on-going study of Islamic "ornament-decoration" applied to an enormous range of surfaces and materials, studied by specialists including art historians. It is rare for the designs-patterns-motifs-numbers /geometry and colours studied to be understood as carrying any implicit text, rather this material is often published, based upon the material employed, in typologies and chronologies of decorationdesign, its development and influence.

One does its seems need to read both the text that is recorded in script(s) and the text(s) that are embodied in the patterns-designs-motifs-colours, at times implicit in epigraphic spaces, and read the numbers that were employed, thereby reading both the explicit and the implicit text on a building, structure or object, rather than "reading" only the explicit text recorded in script, if one is not to join the ranks of the legion of one-eyed epigraphers, Epigraphos monophthalmos.

It seems possible that much of the impetus behind this practice comes from the language itself, more particularly from the alphanumeric scripts, the scripts employed to record the sacred monotheistic texts, Hebrew, Aramaic, Greek and Arabic, where a letter can be read as a letter, but also can be read as a number, and the letters of a word can be added together as numbers to give a number that represents the word, but also may mean something else, which in turn can stand as a symbol in relation the first word. In consequence, to change the content of the modern acronym wysiwig, 'what you see is what you get,' in an alphanumeric script, 'what you see as text is not all you get,' wysatinayg. When this manner of thinking is applied to the making of designs and patterns, sometimes formed of letters or numbers repeated, or numbers of colours or numbers of motifs repeated, or patterns constructed of shapes having a particular number of sides, you can see pattern/design and both count and read a "text" or "texts" implicit in the pattern-design employed within a particular cultural context and accessible to those possessing a certain type and level education. It is perhaps being brought up to think and articulate in a non-alphanumeric language such as English, French, Spanish or German that perhaps makes this matter of recognising and reading an "implicit", as well as the explicit text, initially seem somewhat far-fetched and mysterious. Perhaps the most well-known of examples of this way of thinking are the chronograms recorded in text and inscriptions, where the letters of the words employed also carry the date of completion of the work, or 
record the date on a tombstone.

It was of course the case that the works produced from the designs supplied by the nakkashnaqqash ${ }^{20}$-designer ${ }^{21}$ were intended to be read and understood as representing a complete and individual multi-layered whole, of which the text recorded in letters often formed only a part of the epigraphic program on a structure, building or object, text recorded in script which needed to be combined with the text recorded in design and pattern and number and colour as noted above. While "form (surat) is but foam in the ocean of meaning (ma'ni)"22, there is unfortunately no more than a hint offered for a more complete approach to the study of Medieval Islamic epigraphy and consequently of approaching the meaning embodied in the work, provided in the publishers' description of the contents of this Cambridge University Press 2015 volume: "Inscriptions convey meaning not just by their contents but also by other means, such as choice of script, location, scale, spatial organisation, letterform, legibility and clarity. The essays in this book consider these visual qualities of inscriptions, ranging across the Mediterranean and the Near East from Spain to Iran and beyond, including Norman Sicily, Islamic North Africa, Byzantium, medieval Italy, Georgia and Armenia. While most essays focus on Late Antiquity and the Middle Ages, they also look back at Achaemenid Iran and forward to Mughal India. Topics discussed include real and pseudo-writing, multilingual inscriptions, graffiti, writing disguised as images and images disguised as words. From public texts set up on mountainsides or on church and madrasa walls to intimate craftsmen's signatures, barely visible on the undersides of precious objects, the inscriptions discussed in this volume reveal their meanings as textual and visual devices."

This book consists of an introduction: viewing inscriptions by the editor A. Eastmond followed by 11 chapters and an Afterword: re-viewing inscriptions by the editor. The chapters are entitled:

1. Text, image, memory, and performance: epigraphic practices in Persia and the ancient Iranian world, by M. P. Canepa

2. Prayers on site: the materiality of devotional graffiti and the production of early Christian sacred space, by A. M. Yasin

3. Erasure and memory: Aghlabid and Fatimid inscriptions in North Africa, by J. Bloom

4. Textual icons: viewing inscriptions in medieval Georgia, by the editor

5. Pseudo-Arabic 'inscriptions' and the pilgrim's path at Hosios Loukas, by A. Walker

6. Arabic inscriptions in the Cappella Palatina: performativity, audience, legibility, and illegibility, by J. Johns

7. Intercession and succession, enlightenment and reflection: the inscriptional and decorative program of the Qaratay Madrasa, Konya, by S. Redford

8. Remembering Fernando: multilingualism in medieval Iberia, by T. Nickson

20 "nagash", etc.

21 A naqqash being someone who makes a naqsha (a drawing, design, plan, portrait), whether a painter, a limner, an embroiderer, an illuminator (of books), a sculptor, a carver, an engraver, a draftsman, or a designer. Nakkaş Turkish from the Arabic. Hence Nakkaşhane-design studio.

22 Aflaki Manaqeb al-arefin V. 15. 
9. Displaying the word: words as visual signs in the Armenian architectural decoration of the monastery of Noravank (fourteenth century), by I. Rapti

10. Written in stone: civic memory and monumental writing in the Cathedral of San Lorenzo in Genoa, by S. Gerevini

11. Place, space, and style: craftsmen's signatures in medieval Islamic art, by S. S. Blair

The subject of this review is the seventh chapter of this volume Viewing Inscriptions in the Late Antique and Medieval World, which is 22 pages long, entitled, 'Intercession and Succession, Enlightenment and Reflection: The Inscriptional Program of the Qaratay Madrasa, Konya' by S. Redford. Unfortunately but typical of the western-modern trained study of the inscriptions on Medieval Islamic structures and objects, in the description provided of the inscriptional program of the Qaratā'i Madrasa, Konya, only the explicit text, the text recorded as script in letters, is read. The "text" embodied in the patterns and designs employed on the Qaratā'î Madrasa, that is, the 'implicit' text is left entirely "unread" and its presence as "text" is not indicated, it is described as decoration, as in: "The glazed surface of all surviving tiles is covered with stencilled gilded geometric and floral decoration, often featuring the six-pointed star known in Islamic cultures as the seal of Solomon" ${ }^{23}$.

It is of course the case that the explicit text recorded on a structure such as the Qaratā' $\bar{\imath}$ Madrasa needs to be read, one needs to read the outward-evident, As-Zahir, but also perhaps, if one is addressing "The Inscriptional Program of the Qaratay Madrasa, Konya", it is the case that one needs also to attend to the inward-concealed, the implicit text, Al-Bartin and, if possible, to bring these two types of epigraphic material together, the exoteric and the esoteric, to read the whole of the epigraphic document. This is made explicit through the choice of the particular texts that are recorded in script on the entrance portal to this building.

The Qur'anic inscription band on either side of the muqarnas over the entrance to the Qaratā'i Madrasa, Konya of $1251^{24}$, records the $19^{\text {th }}$ Ayet of the Sūrat An-Naml 27. It reads in

23 Redford 2015, 155.

24 The splendid inauguration ceremony held by Jālāl al-Dīn Qaratā'ī on the completion of the construction of his madrasa is recorded, together with the dispute concerning which seat and precisely where was in fact, the seat of honour, but no precise date is given for this inauguration ceremony: "When the construction of his madrasa was completed, Jālāl al-Dīn ordered a splendid inauguration ceremony to be held, and it was on that day that among the prominent religious scholars a discussion took place about which seat is the seat of honor. That day Mowlānā Shams al-Dīn-e Tabrizi had only recently arrived and he sat among the people in the place where one removes one's shoes. With one accord the asked Mowlānā: 'What place is called the seat of honor?' He replied: 'The seat of honor of the religious scholars is the middle of the raised platform and the seat of honor of the knowers of God ('orafā) is in the corner of the house and the seat of honor of the Sufis is on the side of the raised platform and, according to the practice of lovers (of God 'āsheqān), the seat of honor is alongside the friend.' He then rose and sat down next to Shams al-Dīn-e Tabrizī. They say that was the day Mowlānā Shams al-Dīn-e Tabrīì became well known among the prominent men of Konya", Aflaki Manaqeb al-arefin III. 38. The opening of the Qaratā'i madrasa was in the same Sunni-Seljuk state inauguration tradition as that recorded for the opening of the Nizāmiyya madrasa in Baghdad on the 10 Dhu al-Hijja 459/22 $2^{\text {nd }}$ September 1067, Ephrat 2011, 144. Further, Aflaki also records on the matter of the seat of honour, that Shams al-Dīn-e Mārdīnī saw in a dream, "the Sultan of the Prophets and the Envoys, Muhammad the Messenger of God - God's blessings and peace be upon him - seated in the seat of honour in the șoffa of the Madrasa of Jālāl al-Dīn-e Qaratā'̄̄" Aflaki Manaqeb al-arefin III. 118, and so, it would 
transliteration:

fa-tabassama d̦āhikan min qawlihā wa-qāla rabbi 'awzi'nī 'an 'ashkura ni mataka llatī 'an 'amta 'alayya wa- 'alā wālidayya wa-'an 'a 'mala șālihan tarḍ̄hu wa-'adkhilnī bi-rahmatika fi 'ibādika ș-șāliḥin

In translation:

"And (Solomon) smiled, laughing at her speech, and said: My Lord, arouse me to be thankful for Thy favour wherewith Thou hast favoured me and my parents, and to do good that shall be pleasing unto Thee, and include me in (the number of) Thy righteous slaves" 25 .

As also:

"Whereat he smiled, amused at its words (the words of the ant), and he said, 'My Lord! Inspire me to give thanks for Your blessing with which You have blessed me and my parents, and that I may do righteous deeds which may please You, and admit me, by Your mercy, among Your righteous servants" ${ }^{26}$.

The author writes concerning this text:

"The quotation is from the Sura of the Ant, verse 19, which recounts the deed of Solomon, a prophet in Islam. Solomon also held a special place in mystical Islam because of his esoteric knowledge, in this chapter the knowledge of the language of birds and insects. This verse introduces us to the concept of God granting prophets(sic) esoteric knowledge and, without identifying him by name, introduces Solomon (and indirectly, his father David, who is named in the previous verse)"27.

There are both factual errors and omissions in this passage.

Firstly some errors

The author writes, "his father David, who is named in the previous verse"; yet the Prophet Dāwūd-David, father of the Prophet Sulaymān, is not named in the previous Ayet, Ayet 18, nor yet in Ayet 17, which describe the muster of the hosts of the Prophet Sulaymān, consisting of Jinn and men and birds, and their march and arrival at the Valley of the Ants. It is the case that the Prophet Dāwūd-David, father of Sulaymān/Solomon is mentioned in both Ayet 16 and Ayet 15 of Sūrat An-Naml 27.

Likewise, for the author to state of Ayet 19 of Sürat An-Naml that, "This verse introduces us to the concept of God granting prophets (sic) esoteric knowledge.", doubtless provides the reader with a somewhat surprising interpretation of this Ayet, an interpretation which seems to be entirely unknown in the $13^{\text {th }}$ century, as otherwise unrecorded today. Quite how this particular Ayet "introduces us to the concept of God granting prophets esoteric knowledge.", is somewhat less than evident in the reading of it. What the author relates concerning the content of this Ayet is quite simply unrecorded in this Ayet, hence raising the possibility of some mistake or confusion made by the author and unrecognised by the editor. It is surely amongst the

27 Redford 2015, 150. 
definitions of the nature of Prophet-hood itself to have been granted esoteric knowledge by the Almighty, being a type of knowledge known to only the $\mathrm{few}^{28}$, and without this esoteric knowledge what perchance would a Prophet profess?

Further, it is perhaps noteworthy that through the author's use of the word, 'concept', meaning a human conceit or notion from the Latin conceptum ${ }^{29}$, in the phrase, "introduces us to the concept of God granting prophets esoteric knowledge", a misapprehension may arise in the mind of the reader, as this phrase unfortunately can be read as suggesting the Almighty is just a human notion. In a chapter concerning the "The Inscriptional Program of the Qaratay Madrasa, Konya", a mid- $13^{\text {th }}$ century building constructed to serve the religion of Islam, any possible personal religious/atheistic concerns of the author of this chapter in the $21^{\text {st }}$ century are of course neither of interest or consequence, and consequently any expression of doubt the author may unintentionally or otherwise have inserted into a matter of faith, belief and knowledge in and of the Almighty in the $13^{\text {th }}$ century through employing this ill-chosen expression, seems most unfortunate. As likewise, in the concluding section of this chapter subtitled, discussion and conclusion, where the author writes: "Muhammad had a prominent role in Islam, mystical or not, as an intercessor, so his prominence in the inscriptional program of the fan pendentives comes as no surprise." ${ }^{30}$, and although, in respect to the Prophet Muhammad's role as intercessor this use of the past tense is not repeated in a subsequent sentence, "According to Islamic belief, Muhammad intercedes with God on behalf of believers on Judgement Day" ${ }^{31}$, the way the former sentence is structured seems somewhat careless, with the suggestion made through the use of the past tense that the Prophet Muhammad no longer has a prominent role in Islam as an intercessor on behalf of Muslims with the Almighty, in contradiction to usual understanding and interpretation, particularly in respect to the Day of Judgement.

It is surely likewise the case that the author intended to convey to the reader the idea that it is the prominence of Muhammad's name in the inscriptional program of the fan pendentives which comes as no surprise, rather than what is written, "his prominence in the inscriptional program of the fan pendentives comes as no surprise".

Concerning this apparent careless in the use of language, odd one may think for a professor concerned in part with the translation and publication of epigraphic texts, which could almost be mistaken for a lack of respect concerning the religion of Islam, there is also the author's suggestion that:

28 As for example in respect to the Prophets and rasul Allāh, Holy Qur'an Sūrat An-Nisā (Women) 163-165, "Lo! We inspire thee (Muhammad) as We inspired Noah and the prophets after him, as We inspired Abraham and Isaac and Jacob and the tribes, and Jesus and Job and Jonah and Aaron and Solomon, and as We imparted unto David the Psalms; And messengers We have mentioned unto thee before and messengers we have not mentioned unto thee; and Allah spoke directly unto Moses; Messengers of good cheer and of warning, in order that mankind might have no argument against Allah after the messengers. Allah was ever Mighty, Wise".

29 SOD $^{3}$ defines the word: 1 . Concept=Conceit, 2. Logic and Philos. The product of the faculty of conception; an idea of a class of objects, a general notion. "Concepts are merely the results, rendered permanent by language, of a previous process of comparison" Sir W. Hamilton.

30 Redford 2015, 163.

31 Redford 2015, 163. 
"The prescription of celebration of these holy nights in the madrasa ${ }^{32}$ can be tied not only to Sunni Muslim practice at this time but also to a possible self-identification of the ascetic/mystic emir (Jâlāl al-Dìn Qaratāîi) with the Prophet Muhammad himself ${ }^{33}$.

For the author to suggest "a possible self-identification" of Jālāl al-Dīn Qaratā'î with the Prophet Muhammad, on the basis of the nocturnal celebration of these holy nights in the Muslim calendar in his madrasa, is frankly absurd. Daphna Ephrat relates, "sources from $6^{\text {th }} / 12^{\text {th }}$ and $7^{\text {th }} / 13^{\text {th }}$ (century) Syria report that crowds gathered in congregational mosques for ceremonious prayers five nights of the year: the blessed night of mid-Sha'ban, $27^{\text {th }}$ Ramadan, the night of 1 Muharram, and the nights of the two festivals. They lightened(sic) candles and kindling oil all night long." ${ }^{34}$, citing Daniella Talmon-Heller ${ }^{35}$, who does not suggest any "possible self-identification" of these thousands of worshippers with the Prophet Muhammad as a result of this activity. And to suggest "a possible self-identification" of the Emir Jālāl al-Dīn Qaratā'î with the Prophet Muhammad, unsupported by clear evidence, suggests not academic carelessness but the invention of a studied, carefully worded and deliberate misunderstanding published in a scholarly work ${ }^{36}$.

The author writes, "...verse 19, which recounts the deed of Solomon, a prophet in Is/am" ${ }^{37}$. Yet, with the possible exception of the prayer uttered by this Prophet and the smile brought to his face, if one interprets either of these as "the deed", meaning a particular action rather than words; there is simply no account provided of "the deed", nor of any deed accomplished by the Prophet Sulaymān in Ayet 19 of Sūrat An-Naml. The Prophet Sulaymān's ability to understand the language of other creatures, from Jinn to birds, and the cause of his smile, understanding the ants' conversation, is not a deed, being a gift from the Almighty.

The author also writes: "A shallow muqarnas vault rises above the doorway. At the level of the base of this vault, the muqarnas is flanked by an unusual Qur'anic quotation, which itself runs(sic) across the façade just above the level of the top of the hadith surrounding the entranceway" ${ }^{38}$. However, the text of this Ayet does not in fact "run" across the facade, it breaks on either side of the shallow muqarnas vault, as earlier in this chapter it been somewhat more accurately noted by the author, "An unusual Qur'anic quotation runs(sic) on either side of the entrance ${ }^{\prime \prime 39}$.

Concerning some of the omissions:

The author writes, "Solomon also held a special place in mystical Islam because of his esoteric

32 Celebrations marking the birth of the Prophet Muhammad on $12^{\text {th }}$ of Rabi-ul-Awwal, $24^{\text {th }}$ Ramadan, the beginning of the revelation of the Holy Qur'an Sürat 53:1-12; 2:97 and al-'Isrā' wal-Mi'rāj, the Night Journey, $27^{\text {th }}$ Rajab, Holy Qur'an Sürat 17:1, 62; 53:13-18, specified in the foundation charter of this madrasa.

33 Redford 2015, 149.

34 Ephrat 2011, 152

35 Talmon-Heller 2007.

36 A similar attitude is likewise apparent in the author's article entitled "The Kıble Wall of the Kargı Hanı", Redford 2007, 351-367.

37 Redford 2015, 150.

38 Redford 2015, 153

39 Redford 2015, 150. 
knowledge, in this chapter the knowledge of the language of birds and insects." Yet, in addition to the Prophet Sulaymān's knowledge of the language of birds, animals and insects, his esoteric knowledge extended to communication with, and control over the Jinn, a fact which is recorded in this Surrat An-Naml, Ayet 17, which the author for some reason chose not to mention, but which is perhaps a more remarkable fact, as others who are not known to have been Prophets are recorded as knowing and speaking the languages spoken by creatures such as wolves and a $\operatorname{cow}^{40}$, and there are at least 146 explicit and implicit mentions of the Jinn in the Holy Qur'an, implicit as in 'Ālamin (meaning mankind and jinn and all that exists, as in Sūrat Al-Fātihah 1:2), including the seventy-second Sūrat entitled Al-Jinn.

This Ayet explicitly states: "Inspire me to give thanks for Your blessing with which You have blessed me and my parents,". That is, it records parents in the plural, yet the author excludes one of these parents, writing: "This verse ... introduces Solomon (and indirectly, his father David, who is named in the previous verse)." David, as noted above, is in fact not mentioned in the previous verse, and the author has excluded from mention the lady Saba (recorded as Bathsheba, widow of Uriah the Hittite, in the Judeo-Christian tradition), who is also indirectly mentioned in this Ayet as a parent, one of the wives of the Prophet Dāwūd-David and the mother of the Prophet Sulaymān/Solomon.

This Ayet is then described by the author three times as being an unusual Qur'anic quotation: "An unusual Qur'anic quotation runs(sic) on either side of the entrance." 11 , "A shallow muqarnas vault rises above the doorway. At the level of the base of this vault, the muqarnas is flanked by an unusual Qur'anic quotation, which itself runs(sic) across the façade just above the level of the top of the hadith surrounding the entranceway" ${ }^{42}$. "...the unusual inclusion of a Qur'anic inscription giving voice to Solomon on the portal" ${ }^{\prime 3}$. But in what sense this Qur'anic quotation is unusual is not stated. Is it unusual in "giving voice to Solomon on the portal", unusual in relation to what, intention, common practice, Islamic speaking sculpture etc., the author fails to clearly establish for the reader. I personally find the Arabic inscription does not "run" or appear to "run" anywhere, being carved in stone and formerly doubtless gilded", and the choice of the adjective "run" applied to this Ayet in what the author describes as, "an elegant cursive script... written in a style more reminiscent of a Qur'anic chapter heading" seems

40 See for example, Sahih Al-Bukhāri vol. 5, 3663 (O.P.15), where the words spoken by a wolf were understood by a shepherd and the words spoken by a cow were understood by a man. For another example from near Al-Madinah of a wolf speaking to a person and mentioning the name Allāh, within the Prophet of Islam's temporal lifetime, see the narration of Abū Sa'îd Al-Khudri, recorded in the Musnad Imam Ahmad in the Musnad of Abū Sa'îd Al-Khudri, where it is recorded that the Day of Resurrection will not be established until beasts of prey speak to human beings, that is that human beings will then understand the languages of the beasts of prey. At that time when ones very limbs will speak, hands and feet speaking to the Almighty, as ones mouth is sealed, Holy Qur'an Sūrat Yā Sinn 65, "This day We seal up their mouths, and their hands speak out to Us and their feet bear witness as to what they used to earn" (Trans. Picthall 1998).

41 Redford 2015, 150.

42 Redford 2015, 153.

43 Redford 2015, 162.

44 That this cursive script, "reminiscent of a Qur'anic chapter heading", (Redford 2015, 151) "runs", as likewise, "Just as the Throne Verse running around the arch of the iwān..." (Redford 2015, 156), is of itself of course an odd and faintly amusing or offensive choice of adjective, dependent upon your faith or lack of it. 
somewhat odd, and, although Islamic speaking statues are recorded ${ }^{45}$, there is simply no evidence whatsoever for the author's apparent suggestion that there was "a Qur'anic inscription giving voice to Solomon on the portal.", implying there was a system in the $13^{\text {th }}$ century whereby a recitation of this Ayet came through the stonework of this inscription. If evidence can be found to support this unsubstantiated statement of "a Qur'anic inscription giving voice", then the adjective unique, rather than the "unusual" employed, would, one would think, be more appropriate within this $13^{\text {th }}$ century context. Today, coloured neon inscriptions giving voice are not unknown ${ }^{46}$.

The realisation of a further omission of significant concern occurs when reading this chapter's concluding remarks. One may wonder if an important part of this chapter's text has vanished in the course of its passage from author to printer, as the author writes: "In finding analogies between the neoplatonic structures of Sufi thought, with their levels of meaning, and the levels of ornament and writing in the domed courtyard of the Qaratay madrasa, I hope to have grounded my argument securely enough in the cultural circumstances of mid-thirteenth century Konya and the person of Jalal al-Din Qaratay..." ${ }^{47}$. However, in the previous seventeen pages of this chapter there is no record of any analogies found, no argument drawn or recorded concerning the levels of ornament and writing in the domed courtyard of the Qaratay madrasa and Neo-Platonic structures with their levels of meaning in Sufi thought. Although Ibn Bibi in the $13^{\text {th }}$ century made this association in relation to the Emir Qaratā' 1 in his work ${ }^{48}$, there is not one earlier mention of Neo-Platonism, nor of mention of Neo-Platonic structures of Sufi thought and levels of meaning contained within the published version of this chapter ${ }^{49}$. Either the author forgot to include the argument and the evidence of analogies between the levels of inscriptions and ornament in the madrasa and the levels of meaning in Sufi Neo-Platonic structures of thought, which he writes in his conclusion he had found; or the relevant passage and notes have been excised for some reason from the text by author or editor, with this unreferenced but possibly important sentence left behind, hanging in the conclusion, a lure perhaps, or a considered Sufistic gesture to the reader ${ }^{50}$, or a possible oversight or an error, but which remains perhaps evidence of a less than close authorial-editorial reading of the pre-publication proof.

A further matter concerns how the Regent Qaratā'i and his Qaratā'i madrasa in Konya were understood by his contemporaries. The Regent Qaratā'i had been an East Roman Christian slave convert to Islam who rose to become Atabeğ-Emir and the Regent, in effect, the ruler of the Seljuk sultanate, while at the same being abstemious and a follower of the Path ${ }^{51}$, employing

45 Duggan 2009.

46 Such potential as indicated for example by Manal Al-Dowayan's 2010 work in neon with black paint, $20 \mathrm{x}$ $100 \mathrm{~cm}$, entitled: We Were Together Speaking Through Silence, at Tashkeel al-Fahidi, Dubai, United Arab Emirates: Source: http://tashkeel.org/exhibitions/collacurating-sculptural-perspectives

47 Redford 2015, 165.

48 Ibn Bibi II. 125.

49 Concerning the Neo-Platonic structures of Sufi thought see for example Morewedge 1992, who however remarks that, "the metaphysics of Ultimate Being in Islam is a modification and not a deduction of Neoplatonism." Morewedge 1992, 71.

50 Possibly on the lines of some Sufi teaching stories, such as "The Elephant in the Dark".

51 Ibn Bibi II. 125. 
the title Vali Allah fi'l-ard, the Friend of Allāh on earth. It was understood that the Qaratā' madrasa housed the tomb-turbé of the ruler, the ruler of the Sultanate, Jālāl al-Dīn Qaratā'î on behalf of the Almighty, the Abbāsid Caliph, the teenage Sultan 'Izz al-Dīn and the two underage Seljuk princes Kılıc Arslan and 'Ala' al-Dīn Keykubad. It is therefore as a complex, to be "read", in part at least, as an 'Islamic Royal Medrese-Tomb' complex, as for example those later Islamic Royal Medrese-Tombs of $14^{\text {th }}$ century Mamlūke Sultans and with elements of the tradition of the Tomb-Medrese complex that date back to the construction of the madrasa complex around the tomb of Abū Hanīfa in the Bāb al-Tāj quarter of Baghdad, constructed in 1066 by Sharaf alMulk Abū Sa'd al-Mustawfī, the first madrasa for the Hanafī madhhab in Baghdad ${ }^{52}$. The author notes that: "Ibn Bibi writes that Jalal al-Din Qaratay was possessed of the spirit of Suhayb (a companion of the Prophet known for his abstemiousness) and with knowledge of the esoteric (asrār-e ghayb). Still despite shared nomenclature, a spiritual gap exists between saints and prophets" ${ }^{\prime 53}$. This passage was written perhaps without understanding fully, or wishing to disclose the point that was being made by Ibn Bibi concerning his analogy between Jālāl al-Dīn Qaratā' $\bar{i}$ and the spirit of Suhayb, it was not just that Suhayb was a Companion of the Prophet, an ascetic and had a real knowledge of the esoteric. Suhayb ${ }^{54}$, as a boy was enslaved by the East Romans c.591 during a raid near al-Uballah (Basra) and after years of slavery escaped to Makka and became a follower of the Prophet Muhammad before the hijra. In consequence of his time as an East Roman slave he was called Suhayb bin Sinan ar-Rūmi. He was a sahabah - Companion of the Prophet noted for his abstemiousness and generosity to the poor and a follower of the Path (the esoteric- asrār-e ghayb) as is noted by the author, but also, and importantly in this context, he was nominated by the Second Caliph 'Umar as he was dying, to lead the Muslims in prayers and, consequently, for the brief three day period between the death of 'Umar and 'Uthman's appointment as Caliph, Suhayb bin Sinan ar-Rūmi was responsible for leading prayers and so, was in effect, the temporary caliph - briefly in November h. 24/644 A.D. It was for these parallels, concerning the Rūmī (The (East) Romans), enslavement, change of religion, personal abstemiousness and generosity to the poor and as a follower of The Path that Ibn Bibi related that Jālāl al-Dīn Qaratā'î and Suhayb shared a spiritual relationship; as it was doubtless understood by Ibn Bibi's readers at the time and so was not remarked upon, that both had in common a temporary period of temporal ruler-ship, respectively as Regent and as Caliph.

52 Ephrat 2011, 140.

53 Redford 2015, 164.

54 "It is narrated from Hamza ibn Suhaib that Suhaib Al-Rumi [RA] used to have the kunya (nickname) "Abu Yahya", used to say that he is an Arab and used to give out a lot of food to people. So Umar [RA] said to him, "O Suhaib! Why is that you are given the kunya (nickname) "Abu Yahya" (i.e. father of Yahya) while you don't have a child, you say that you are an Arab, and you give out a lot of food to people while that is و excess in wealth?". So Suhaib [RA] replied, "Without a doubt, the Prophet of Allah ملس gave me the kunya (nickname) "Abu Yahya". As for your statement about my lineage, I am a man from Namir ibn Qasit from the people of Mawsul (one of the tribes of the Arabs) [i.e. my lineage is Arab] but I was captured as a slave when I was a young boy and as a result I surely neglected my family and people. As for your statement about the food (that I give out), without a doubt the Prophet of Allah used to say: "The best of you are those who give food to people and those who return

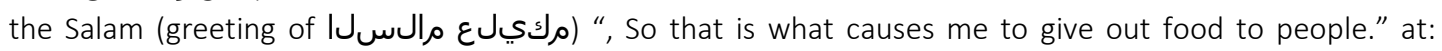
https://ilookilisten.wordpress.com/2014/04/02/the-story-of-suhaib-ibn-sinaan-ar-rumi-radiallahu-anhuhadith-no-1917/ 
The Portal, the Prayer, the Seljuks, the Prophet Sulaymān and the Seal

Certainly noteworthy in this respect is the inscription recording the $19^{\text {th }}$ Ayet of Surrat An-Naml and the position that it occupies on this facade, to either side of and rising from the same level as the muqarnas rising up on either side of this niche, although the muqarnas rise from a slightly higher level along the rear wall, to fill most of the area of the flattened niche above the entrance. If muqarnas are to be understood as being a representation of the piercing multifaceted nature of the Divine Light - a representation of the Light of the Almighty - nūr-i ilähi, then by placing the words of this Qur'an Ayet at the same level on the facade, an association can be drawn by the attentive reflective viewer between the representation of the Divine Light, the recitation of the Holy Qur'an and the inscription of this Ayet, presumably formerly gilded ${ }^{55}$, recording a prayer made by the Prophet and Ruler Sulaymān.

Perhaps a part of the reason why this Ayet is recorded in this position on the entrance portal of the Karatay Medrese, in larger letters and slightly above the hadith surrounding the doorway - was not only because of âdet or manners, quite simply that the Word of the Almighty as recorded in the Holy Qur'an takes precedence in importance over the relations recorded in the hadith literature - but because it seems to be the case that part of the reason why this particular Ayet was chosen for this facade, almost certainly a personal choice made by the Emir Qaratā'i, effectively the ruler as regent of Rūm Seljuk territory under the temporal over-lordship of the Pagan Mongols in 1250-51, was because of the shared intention expressed in the prayer uttered by the Prophet and Ruler Sulaymān recorded in this Ayet:

"My Lord! Inspire me to give thanks for Your blessing with which You have blessed me and my parents, and that I may do righteous deeds which may please You, and admit me, by Your mercy, among Your righteous servants."

With the hope stated through the employment of this Ayet that the construction of this madrasa would be understood by the Almighty as being a righteous deed, raised in thanks for the blessings bestowed by the Almighty upon the Emir Qaratā'i and his parents, understood as being a work (a deed) carried out by the righteous slave of the Almighty, and to request of the Almighty mercy and his admission to the ranks of the righteous servants of the Almighty, not least, in consequence of his advancing age and with his tomb constructed within this Qaratā' madrasa. Consequently this inscription can be understood as being a form of foundation inscription for the madrasa (and the tomb it contains), displaced to the sides from its more usual position over the door, a supplicatory form of foundation inscription, with the rest of the foundation inscription, beginning with the more usual Qur'an citation for a building's foundation inscription, from Surrat At-Taubah 9:121, extending across the top of the facade below the outermost border of the portal.

It seems largely unremarked upon, and is not noted by the author in this chapter, but a possible further supporting reason for the choice and use of this particular text on the entrance facade of the Madrasa of Jālāl al-Dīn Qaratā'î, an Ayet concerning the Prophet Süleyman, his amusement and smile and his supplication to the Almighty, and for the implicit association drawn through the use of this Ayet relating this prayer of the Prophet Sulaymān with the defacto ruler, the Regent of the Rūm Seljuk state, the Emir Qaratā'i , who ordered the construction

55 For gold gilded inscriptions on exterior walls of Ayet from the Holy Qur'an see: Ibn Bibi I. 272-273. 
of this madrasa, was the longstanding association of Rūm Seljuk Sultans with this Prophet and ruler. Ibn Bibi describes the arrival of the Rūm Seljuks in the lands of Rūm as being brought to this territory by the wind-breath of the Prophet Sulaymān ${ }^{56}$, a reference to both the Prophet Sulaymān ${ }^{57}$ and to the name and actions of the founder of the Rūm Suljuk Sultanate, Melik Süleyman b. Qutlumush (1081-6). This name was also given to one of the sons of Sultan Kılıç Arslan II (r. 1156-92), the future Sultan Süleyman II Rukn al-Dīn (r. 119-1204), while Sultan Kılıç Arslan II, ibn Bibi describes as "The Second Sulaymān" ${ }^{58}$. In the period from 1205 to 1246, that is, from the second reign of Sultan Giyath al-Dīn Keyhusrev I (r. 1205-11) ${ }^{59}$, through the reigns of Sultan 'Izz al-Dīn Keykavas I (r. 1211-20) ${ }^{60}$, Sultan 'Ala' al-Dīn Keykubat I (r. 1220-37) $)^{61}$ and Sultan Giyath al-Dīn Keyhusrev II (r. 1237-46), with his first wife from Georgia described as, like "Belkis" ${ }^{62}$ the wife of the Prophet Sulaymān, each of these Rūm Seljuk Sultans in the surviving literary record was given the laqub "The Second Sulaymān". It seems that following the Seljuk defeat by the Mongols in 1243, probably after 1246, the title, "The Second Sulaymān" was no longer used by Seljuk rulers, but there may be an element of this pattern of former use by the Seljuk Sultans of Rūm that is reflected in the choice and use of this Ayet from the Sürat AnNaml, by the Emir Qaratā'î, de-facto ruler of the Sultanate, under Pagan Mongol over-lordship, on the portal of his madrasa.

Perhaps surprisingly, perhaps fated, the connection of this Prophet's name with the Rūm Seljuk ruler - de facto Rūm Seljuk ruler following the death of Emir Qaratā'î in 1254 continued under Mongol over-lordship, through the Pervâne Mu'in el-Dīn Sulaymān, in the period from 1261 until 1277 (the Pervâne Mu'in el- Dīn Sulaymān was one of the four contributors to the construction costs in Konya in 1273 of the Kubbe-i Hadra and Jâlāl al-Dīn Rūmi's wooden cenotaph) and his execution by the Mongols due to his conspiring with Sultan al-Malik al-Zāhir Rukn al-Dīn Baibars al-Bunduqdari r. 1260-1277 to free the Rūm Seljuk state from Pagan Mongol control. The Pervâne Mu'in el-Din Sulaymān was not only described by Jālāl al-Dīn Rūmī as behaving like his namesake, the Prophet Sulaymān in exercising command over the Seljuk Dīvān ${ }^{63}$, but in possessing on his forehead, "a Solomonian light which, if it sets out to do so, will seize the dominion of East and West.' They asked: 'Oh indeed! What light is that light!' He replied: "It is the light of our love" ${ }^{64}$. As to if the phrase, "will seize the dominion of East and

56 Ibn Bibi I. 20.

57 Holy Qur'an Al-Anbiya 81 "And unto Solomon (We subdued) the wind in its raging. It set by His command toward the land which We had blessed. And of everything We are aware", (Trans. Picthall 1998), although the use of the word set, with the setting wind suggesting the sunset in the west fortuitously thereby indicting the Rūm Seljuks' westwards movement. In other translations the word set is not used, eg. Sahih International: "And to Solomon [We subjected] the wind, blowing forcefully, proceeding by his command toward the land which We had blessed. And We are ever, of all things, Knowing", Holy Qur'an Sad 36. Ibn Bibi I. 79.

59 Ibn Bibi I. 89-90.

60 Ibn Bibi I. 181.

61 Ibn Bibil. 232, 238 n. 596.

62 Ibn Bibi II. 37.

63 Aflaki Manaqeb al-arefin III. 127.

64 Aflaki Manaqeb al-arefin III. 127. Shams al-Dīn Ahmad-e Aflaki provides another account where Jālāl al-Dīn Rūmī (1207-73) is described as a sultan possessing "Solomonian greatness", Aflaki Manaqeb al-arefin III. 526. While Jālāl al-Dīn Rūmī in his first letter to Shams al-Dīn-e Tabrīzī in Syria describes Shams al-Dīn as 
West ${ }^{\prime 65}$, in reference to the Pervâne, was a reference by Jālāl al-Dīn Rūmī to the long planned uprising against the Mongol overlords, to be combined with the arrival of Sultan al-Malik alZāhir Rukn al-Dīn Baibars al-Bunduqdari and his Mamlūke army, to clear Rūm Seljuk territory of the Pagan Mongols, is unclear. It is however evident that the Pagan Mongols were caught unaware and unprepared for the events of 1277, including the April $15^{\text {th }}$ Battle of Elbistan.

The importance given to this prophet and ruler by the Rūm Seljuk dynasty, an association continued through the use of Surrat An-Naml 27, Ayet 19, as the main inscription on the entrance façade of the Emir Qaratä'î's madrasa, was visibly reinforced in the interior of this building on the tiled revetments of the walls, through the repeated use of "hexagonal tiles with monochrome turquoise glaze. The glazed surface is covered with stencilled gilded geometric and floral decoration, often featuring the six-pointed star known in Islamic cultures as the seal of Solomon" ${ }^{\prime 66}$. This conscious reinforcement of the association of this madrasa with the Prophet and Ruler Sulaymān established through the entrance portal inscription, where the smile of this Prophet and his prayer is recorded, and then, through the use of these hexagonal tiles carrying the seal of Sulaymān design ${ }^{67}$, is not noted by the author.

Jâlāl al-Dīn Rūmī relates of this matter of the seal of the Prophet Sulaymān:

"I wonder what the heart is saying to them (the members of the body). 'Tis a marvellous connexion, a marvellous hidden link.

Surely the heart has gotten the seal of Solomon, so that has ruled the reigns of (external control over) the five senses (faculties).

Solomon:

"Oh Solomon, the hoopoes belong to you.

Be kind and visit us. Come to me!", Aflaki Manaqeb al-arefin IV. 112.

65 As in the phrase, "cause his standard to unfurl in the East and West", for an example of the use of this phrase in an inscription, Redford 2010, 308-309, which, although no noted, was the title 'the East and West' associated with the Seljuk dynasty from 1055 onwards, when the Caliph al-Qā'im gave Tughril Bey the title, "Sultan of East and West", (eg. Hillenbrand 2011, 28, although there seems no evident need to associate this new title given by the Caliph, an addition to the title 'Sultan' as was given to Mahmud of Ghazne, with some nomad tradition) as was likewise given to the Great Seljuk Sultan Malik Shāh in 1087. In c. 1205-1206 it was employed by the poet 'Allama in a qasida from the Khwārazm Shāh, Sultan 'Alā' al-Dīn Muhammad (1200-1220) to the Emir Mahmud, concerning his appeal to be granted the viceroyalty of Firuzkuh:

"Sultan of East and West, Emperor of the East and West

Mahmud, son of Muhammad, son of Sam, son of Hussain", Boyle 1997, 332. It is the probable meaning conveyed in the $13^{\text {th }}$ century by Seljuk and Artukid use of the double headed bird of prey represented in carved stone relief-work, on the coinage, in painted tile-work, some of which carry the text "al-Sultan", eg. Arık 2000 figs. 55, 61, 62 from Kubadabad, as others carry a similar set of titles, "al-muazzam" eg. Arık 2000 figs. 53, 59, 60, as in the titles: 'es-sultan al-muazzam' etc., although the double headed bird cannot be associated with an eagle for obvious reasons, and can most probably, if it absolutely has to be associated with a species of worldly birds, as a double headed falcon. The reason it was employed by the Artukids was because their legitimacy in part stemmed from the appointment of Artuk b. Ekseb as governor of Palestine by the Great Seljuk Sultan Malik Shāh and they became vassals of the Rum Seljuks early in the $13^{\text {th }}$ century, from which date they employed this device and hence their use of this device on coins, in relief carving, as likewise on glazed tile-work, Arık - Arık 2008, 246 fig. 189.

66 Redford 2015, 154-155.

67 For a fine illustration of this see: Öney 1992 res. 62, 116. 
Five external senses are easy for it to manage, five internal senses (faculties) are under its command.

There are ten senses and seven limbs (of the body) et cetera: count over to yourself what is not mentioned (here).

O heart, since thou art a Solomon in empire, cast thy seal-ring upon peri and demon.

If in this kingdom thou art free from deceit, the three demons will not take the seal from your hand;

After that, thy name will conquer the world: the two worlds (will be) ruled by thee like thy body.

And if the demon take the seal off thy hand, thy kingdom is past, thy fortune is dead;" ${ }^{68}$.

It is important to note this depiction of the seal of Sulaymān device on some of these hexagonal tiles, with the 6 points of these tiles forming the tile-work revetments on the interior walls of the central space of this madrasa. One can presume that tiles of this hexagonal form were designed and employed in this madrasa to be "read" as representing through the number 6 of the six points, the letter/word wāw and meaning 'and (Allah)', (as is noted above is likewise the case in respect to the zigzag design) and, consequently, the design representing the seal of Sulaymān depicted on these 6 pointed tiles can be "read" as: representing the seal of the Prophet Sulaymān and the number $6=$ the letter-word $w \bar{a} w$ and the $w \bar{a} w$ read as meaning, and (Allāh). These tiles can therefore be "read" as a reminder of the remembrance of the Almighty in a place where the remembrance of the Almighty was practiced.

On another level the combination of the 6 points of the seal of Sulaymān with the 6 points of the hexagonal tile can be "read" as $6+6=$ the doubled $w \bar{a} w$, being the alphabetical equivalent of the sum of the numerical equivalents of the letters forming the Name Allāh, that is 66 . One can therefore "read" this type of hexagonal tile carrying this design as representing the seal of Sulaymān and the word wāw = and, with the wāw implying, "and (Allāh)." and also reading it as representing the Name Allāh. Further, it is recorded by Abū al-Majd Majdūd ibn Adam Sanā'ī Ghaznavī in his Divān that the wind obeyed the Prophet Sulaymān, "Because Ahmad's (=the Prophet Muhammad's) name is engraved on his seal"69. This seal of the Prophet Sulaymān can also thereby be understood as representing the Seal of Prophethood, that is representing the Prophet Muhammad and, with its sun-shamsa-like form gilded presumably indicating the nür Muhammad - the Light of the Prophet ${ }^{70}$.

Consequently one can "read" this type of hexagonal tile carrying this design as representing:

1. the seal of Sulaymān reminding of the Prophet Sulaymān

2. the seal representing the nür Muhammad - the Light of the Prophet. Muhammad

3. the seal of Sulaymān reminding of the Seal of Prophethood, of the Prophet Muhammad.

68 Jālāl al-Dīn Rūmī Mathnawi I. 3574-3581.

69 Schimmel 2001, 191, SD 167.

70 The Prophet Muhammad is described as the lamp of the world, "O Lamp", Jālāl al-Dīn Rūmī Mathnawi I. 3973. 
Sulaymān Muhammad

4. the seal of Sulaymān reminding of the Prophet Sulaymān and the 6 of the points "read" as the letter/word wāw = and, with the wāw implying, "and (Allāh)." Sulaymān and (Allāh)

5. the seal of Sulaymān reminding of the Prophet Sulaymān, the Seal of Prophethood, the Prophet Muhammad, and the 6 of the points "read" as the letter/word wāw = and, with the wāw implying, "and (Allāh)." Sulaymān, Muhammad and (Allāh)

6. "read" the six points of seal and tile as the numbers $6+6$, representing the doubled wā $w=$ the numerical equivalent of the Name Allāh.

7. "read" the seal itself as carrying the name of the Prophet 'Ahmad'-Muhammad-Mustafa.

8. "read" the seal as representing Ahmad and the 6 points as the word wāw = and, with the wāw implying, "and (Allāh)." Ahmad and (Allāh)

9. "read" the seal as Ahmad and the 6 points of seal and tile as representing $6+6$, the doubled $w \bar{a} w=$ the numerical equivalent of the Name Allāh. Ahmad Allāh

10. See the seal of Sulaymān as a reminder of the Prophet Sulaymān, "read" the seal as carrying the name Ahmad and "read" the 6 points of seal and tile as representing $6+6$, the doubled wāw $=$ the numerical equivalent of the Name Allāh. Sulaymān Ahmad Allāh.

Further, in "reading" the six, of the points of the tile or of the seal, one can also be reminded of Belief in the six: in God, Angels, Books, Messengers, the Resurrection and Fate; as also of the 6 days of Creation ${ }^{71}$, as also of the 6 directions, north, south, east, west, up and down ${ }^{72}$.

In consequence of the above it seems evident that this 'decoration' was designed to be both seen and also to be "read", to remind, and with the explicit statement in the Holy Qur' an that within this temporal world there is the need to remember the Almighty, Sürat Al-'Ankabut, 29:46, "Nothing is greater than the remembrance of God", this decoration designed and employed in this place, where sama was held in "the remembrance of God", carried layers of names implicit in the designs and carried representations-designs that could be read as numbers to be converted into words carrying meanings. This "decoration" is rather a language conveying meaning(s). In this case, at least 7 levels of meaning, the number 7 being understood to mean, like the number 40 , both the exact number and also representing the idea of many. This decoration/design "spoke" in layers and levels of meaning.

The author in his chapter's concluding remarks writes, concerning Seljuk inscriptions that record the name Muhammad in elevated positions that, "The earliest surviving example seems to be the placement of the name Muhammad in star form at the top of a dome of the Ulu Cami at Malatya, which has been dated to 1224" (Fig. 1) ${ }^{73}$.

\footnotetext{
71 Holy Qur'an Sūrat Yunis 3; Hud 7; Al-Sajdah 4. Likewise, Jālāl al-Dīn Rūmī Mathnawi III. 3500.

72 Jālāl al-Dīn Rūmī Mathnawi III. 3108; IV. 1811; VI. 4.

73 Sönmez 1989, 244; Redford 2015, 166.
} 
However, in this context it is worth noting that the name Muhammad is in fact repeated six times in Kufi script along each line of a seal of Sulaymān device in cut-tile work in the apex of this dome. Perhaps the seal of Sulaymān is not best described as a "star-form", not only because there is the established name-term for this form employed in an Islamic context, as had in fact earlier been used by the author ${ }^{74}$, it is termed the seal of Sulaymān, but also because any distinction in form between a star and a sun-shamsa in the $13^{\text {th }}$ century

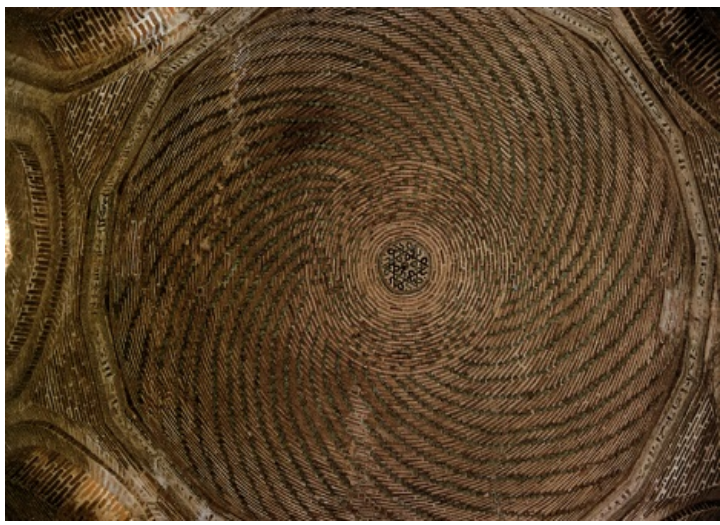

Fig. 1. The Seal at the apex of the dome representing the universe, of the Ulu Cami at Malatya, of 1224. seems less than evident. Consequently, to use the term "star" to describe what may well have been understood in the $13^{\text {th }}$ century as representing a sun in the form of the seal of Sulaymān device ${ }^{75}$, or as representing the Seal of Prophethood, that is representing the Prophet Muhammad/light-sun of the Prophet Muhammad, as also "read" as representing the number 6 and so the latter wā $w$ and so, "and (Allāh)" - as stated by Sheikh Najm al-Dīn Kubrā, as noted above, whose Kubrāwiyya follower, Najm al-Dīn Dāya Rāzī (d. 1256) was sent from Khiva and arrived in the sultanate in Malatya in 1221 when he may have had contact with the calligrapher Ahmed bin Yakub, then Kayseri, Sivas, where he wrote in 1223-4 his influential Mirsād al-'ibād dedicated to Sultan 'Ala' al-Dīn Keykubat I., and settled in Konya ${ }^{76}$ - seems to be both terminologically unhelpful and a hindrance to any attempt to understand the meaning(s) that was conveyed to the $13^{\text {th }}$ century viewer through the use of this design. This design in the apex of this dome of 1224, was presumably drawn by the calligrapher Ahmed bin Yakub ${ }^{77}$, and it seems to repeat in visual form the description of the seal of Sulaymān provided by Abū al-Majd Majdūd ibn Adam Sanā'î Ghaznavī, who was affiliated to Yūsuf al-Hamadānī ${ }^{-78}$, in his lines in the Dīvān- ì Hakim Sanā’î (d. 1131):

\section{"I asked the wind": "Why do you serve Solomon?" It said: "Because Ahmad's (=the Prophet Muhammad's) name is engraved on his seal" 80 .}

And thereby perhaps the earliest example of the depiction in script in an elevated position of name of the Prophet Muhammad to be found in a building constructed in Seljuk territory, in cut-tile work in the apex of the dome of the Congregational Mosque of Malatya (Eski Malatya), is directly associated with the Prophet Sulaymān through the depiction of the seal of the

\footnotetext{
74 Redford 2015, 155; "the six-pointed star (sic) known in Islamic cultures as the seal of Solomon".

75 Duggan 2014, (in particular) 146-147.

76 Schimmel 1978, 257; Cahen 2001, 164.

77 Sönmez 1989, 244.

78 Shushud 1983, 10. In this respect see the section below entitled: On the importance of 'Abdallāh bin Abi Quhāfah aș-Ṣiddīq for the Seljuk Regent and Emir Jālāl al-Dīn Qaratā’î.

79 Holy Qur'an Sürat Al-Anbiya 81; Şād 36 "So We subjected to him the wind blowing by his command, gently, wherever he directed".

80 Schimmel 2001, 191, SD 167.
} 
Prophet Sulaymān combined with the name of the Prophet Muhammad repeated 6 times and one can also therefore read this design as representing the Seal of Prophethood, the name of the Prophet Muhammad and in visual design terms, the name within the Light of the Prophet Muhammad. Further, in view of the subject of the chapter reviewed here, the inscriptional and decorative program of the Regent and Emir Qaratā'î's madrasa in Konya, it is worth noting not only this design on the hexagonal tiles but also this device in its 8-pointed form is depicted within the zone of the pendentives forming Turkish triangles supporting the dome, through the distribution of the names employed, which is entirely unremarked upon by the author of this chapter (see below).

There is one further consideration, also unmentioned by the author, which in addition to the general association of Rūm Seljuk rulers with the Prophet Sulaymān and with his seal, touched upon above, provides a reason for the choice of this text on the entrance facade of this madrasa and this concerns the example understood to have been provided by the Prophet Sulaymān to followers of the spiritual path towards the Almighty. This because this madrasa was designed and constructed to served not only as a place for higher education in the sciences, and with the tomb of its founder, but as a fine meeting place for the "Friends of God", with its founder recorded by Ibn Bibi as employing the title Vali Allah fi'l-ard, the Friend of Allāh on earth ${ }^{81}$. The matter of the importance of the Prophet Sulaymān for the followers of the spiritual path was clarified more than 250 years before the construction of this madrasa by the muhaddith and mystic Abū Ṭālib Muḥammad b. 'Alī b. 'Ațiyya al-Hārithī al-'Ajamī al-Makkī (d. 386 A.H./996 A.D. in Baghdad) who made clear in his influential work entitled Qüt al-qulūb, The Sustenance/Nourishment of Hearts ${ }^{82}$, that it was the profound comprehension of the Almighty that was understood from the $10^{\text {th }}$ century onwards to be the unique, the distinguishing characteristic of the Prophet Sulaymān:

"God has given priority to profound comprehension over discursive knowledge and wisdom, and He has elevated instances of profound comprehension above legal rulings and judgements: (Süratt Al-Anbiyā' - The Prophets, 21:79, which continues: "and to everyone We gave judgement and discursive knowledge."). God therefore equipped Solomon uniquely with the profound comprehension of Him. Making him superior to his father's (David's) ability to render judgement, after He had made the two partners in judgement and discursive knowledge ${ }^{\prime \prime 3}$.

It was understood that it was this inward knowledge that was granted by the Almighty to some Prophets, including the profound comprehension of the Almighty which was understood to have been granted to the Prophet Sulaymān (in addition to his command over the wind, the Jinn, birds, humans and creatures, as also knowledge of the languages spoken by creatures and by mankind and Jinn, both visible and invisible to the human eye), a gift also granted to some

81 As is recorded in this chapter, Redford 2015, 149.

82 al-Makkī Qūt al-qulüb.

83 Renard 2004, 185, Abū Tālib al-Makkī, Kitāb al-'ilm, Chapter 31, Qūt al-qulūb, The Sustenance of Hearts. The understanding of this Ayet therefore differs from the usual interpretation today, which relates this profound comprehension to the legal case mentioned in the preceding Ayet. Holy Qur'an Sūrat Al-Anbiy $\bar{a}^{\prime}$ The Prophets 79, "And We made Solomon to understand (the case); and to each of them We gave judgement and knowledge". 
extent to other spiritual leaders, which was of a different, more elevated and more complete and immediate order of knowledge of the Almighty than that knowledge gained from the study of hadith, and that this was a realisation of knowledge lying within the gift of the Almighty, rather than something to be learnt by repetition and then understood to some degree, "to some degree", as Jālāl al-Dīn Rūmì for example remarks on the 7 levels of meaning of an Ayet of the Holy Qur'an, the levels for the elect and the vulgar ${ }^{84}$, with depths known only to the Almighty, hence the size of the letters of this text of a prayer of the Prophet Sulaymann in this elevated position on this facade, forming the inscription band at the same level as the muqarnas representing the multi-faceted nature of the Divine Light - the representation of the Light of the Almighty-nūr-i ilāhi in the niche, above the entrance doorway with its surrounding inscriptions of hadith carved in smaller characters. This matter of 'His knowledge', that profound comprehension of the Almighty given to the few, epitomised by the Prophet Sulaymān, is repeated thrice in the interior of the madrasa, once in the cut-tile inscription around the iwān arch and twice in the cut-tile inscription around the dome, above and below the band of cut-tile decoration, in the three-fold repetition of Sürat I-baqarah, The Cow, 2:255 (The Throne Ayet) in the phrase:

"... while they encompass nothing of His knowledge save what He will."

This relationship in forms and degrees (stations) of knowledge, indicated by Abū Taâlib Muḥammad b. 'Alī b. 'Ațiyya al-Hārithī al-'Ajamī al-Makkī, that between the Almighty and the Prophet David and his son Sulaymān, partners in judgement and discursive knowledge, but differing in comprehension of the Almighty; is likewise reflected and reinforced in another account of this same type of relationship, that between the Almighty and Al-Khidr and Moses, as recorded in the Sūrat Al-Kahf 18: Ayet 60-83 (the emphasis added):

"And when Moses said unto his servant: I will not give up until I reach the point where the two rivers meet though I march on for ages. And when they reached the point where the two rivers meet, they forgot their fish, and it took its way into the waters, being free. And when they had gone further, he said unto his servant: Bring us our breakfast. Verily we have found fatigue in this our journey. He said: Didst thou see, when we took refuge on the rock, and I forgot the fish-and none but Satan caused me to forget to mention it- it took its way into the waters by a marvel. He said: This is that which we have been seeking. So they retraced their steps again.

84 Jālāl al-Dīn Rūmī Mathnawi III. 1897, "(Such a speaker is) like the Qur'an which is sevenfold in meaning, and in which there is food for the elect and for the vulgar". Likewise, "They know seven (multi) meanings of the Koran. As is said by Muhammad, "The Koran has esoteric as well as exoteric meanings and for the esoteric there are seven layers". Türkmen 2009, 140; Holy Qur'an Sürat āl 'im'rān (The Family of Imrān) 7, "It is He Who has sent down to you the Book. In it are verses that are entirely clear, they are the foundations of the Book; and others not entirely clear. So as for those in whose hearts there is a deviation (from the truth) they follow (only) that which is not entirely clear thereof, seeking Al-Fitnah, and seeking its Ta'wil, but none knows its Ta'wil except Allah. And those who are firmly grounded in knowledge say: "We believe in it; all of it is from our Lord." And none receive admonition except men of understanding". "Ibn Mesud narrates that the Prophet Muhammad used to explain the meanings of the Koran. He explained on meaning to his friends (Ashab) and the other one to me, and if I had disclosed that meaning to them, they would certainly have killed me, because it was a custom to kill a person who spoke blasphemy". Türkmen 2009, 142, clearly evidence for these levels of meaning. 
Then they found one of Our slaves, unto whom We had given mercy from Us, and had taught him Knowledge from Our presence.

Moses said unto him: May I follow thee, to the end that thou mayest teach me right conduct of that which though hast been taught? He said: Lo! Thou canst not bear with me. How canst thou bear with that whereof thou canst not compass any knowledge? He said: Allah willing, thou shalt find me patient and I shall not in aught gainsay thee. He said: Well if you go with me, ask me not concerning aught till I myself make mention of it unto thee. So they twain set out till, when they were in the ship, he made a hole therein. (Moses) said: What! Hast thou made a hole therein to drown the folk thereof? Thou verily hast done a dreadful thing. He said: Did I not tell thee that thou couldst not bear with me? (Moses) said: Be not wroth with me that I forgot, and be not hard upon me for my fault. So they twain journeyed on till, when they met a lad, he slew him. (Moses) said: What! Hast thou slain an innocent soul who hath slain no man? Verily thou hast done a horrid thing.

He said: Did I not tell thee that thou couldst not bear with me? (Moses) said: If I ask thee after this concerning aught, keep not company with me. So they twain journeyed on till, when they came unto the folk of a certain township, they asked its folk for food, but they refused to make them guests. And they found therein a wall upon the point of falling into ruin, and he repaired it. (Moses) said: If thou had wished, thou couldst have taken payment for it. He said: This is the parting between thee and me! I will announce unto thee the interpretation of that thou couldst not bear with patience. As for the ship, it belonged to poor people working on the river, and I wished to mar it, for there was a king behind them who is taking every ship by force. And as for the lad, his parents were believers and We feared lest he should oppress them by rebellion and disbelief. And We intended that their Lord should change him for them for one better in purity and nearer to mercy. And as for the wall, it belonged to two orphan boys in the city, and there was beneath it a treasure belonging to them, and their father had been righteous, and thy Lord intended that they should come to their full strength and should bring forth their treasure as a mercy from their Lord; and I did it not upon my own command. Such is the interpretation of that wherewith thou couldst not bear." Sūrat Al-Khaf 18: 60-82 ${ }^{85}$ Sūrat Al-Kahf 18:65 states Al-Khidr was: "one of Our slaves unto whom We had given mercy from Us, and had taught him knowledge from Our presence.", indicating the comprehension given by the Almighty to this slave of the Almighty, Al-Khidr.

That profound comprehension of the Almighty given to the Prophet Sulaymān, who is reported in Islamic tradition to have reclaimed the shattered fragments of the world mirror given to Adam by the Almighty, and who had seen in its reflection the world ${ }^{86}$, a matter

85 This relationship between the Prophet Moses and Al-Khidr is further related in Sahih Al-Bukhāri VI. 60, Hadīth 249.

86 Kitâb al- Hadâyâ wa al-Tuhaf 175. Relatedly, "Like a barber who first gives some nuts and dry grapes to a child to soothe before using the razor, God makes a man busy with the worries first and then bestows upon him His light. Previously, the mirror of the man was broken and he, who first possessed love of God, now 
concerning the purification and polishing of the heart ${ }^{87}$ so that it can reflect The Light ${ }^{88}$, "It is necessary to bring before God most High a heart mirror bright, so that He may see Himself in it." ${ }^{\prime \prime 9}$, with "the stainless mirror of the higher and lower realities" ${ }^{\prime \prime 0}$ being the Perfect Man (insān $k \bar{a} m i l)^{91}$, was and remains a fundamental aim of the spiritual path and the quest for proximity to the Face of the Almighty, and it was this task which is suggested here was perhaps the primary reason for the construction and selection of designs and texts employed in this madrasa.

It was by approaching and passing through the portal with its reminder of the prayer of the Prophet and ruler Sulaymān, as also the prayer of the Regent and Emir Jālāl al-Dīn Qaratā'î, it is a prayer that stands repetition, through the doorway surrounded by hadith, via the vestibule that the inside of this madrasa was reached, the place where the Friends of God met and held the dervish remembrance of the Almighty, sam $\bar{a}^{92}$, meetings hosted/attended by the Regent and Emir Jālāl al-Dīn Qaratā'̄', Vali Allah fi'l-ard, the friend of Allāh on earth ${ }^{93}$, with some samā

begins to possess God Himself", Türkmen 2009, 109. As likewise Ibn 'Arabī relates, "He is the mirror in which you see yourself, and you are the mirror in which He sees His Names and the manifestation of their status. And they are none other than He!" Addas 1993, 283; "When the mirror of your heart becomes clear and pure, you will behold images (which are) outside of (the world of) water and earth. You will behold both the image and the image-maker, both the carpet of (spiritual) empire and the carpet-Spreader", Jālāl al-Dīn Rūmī Mathnawi II. 72-73.

87 As the hadith records, "The believer is the mirror of his fellow believer" Jālāl al-Dīn Rūmī Fîhi Mâ Fîhi 6. "The Sufis polish their breasts with invocation and meditation so that the heart's mirror may receive virgin images (from the unseen world)." Jālāl al-Dīn Rūmì Mathnawi I. 3154; likewise, "Behold the beauty of the heart, how its moon scatters the Pleiades (how its light is broken and disordered) by a single handful of clay." Jālāl al-Dīn Rūmī Mathnawi I. 3992; "Since the true believer is a mirror for the true believer, his face is safe from defilement." Jālāl al-Dīn Rūmī Mathnawi II. 30.

88 Concerning the polishing of the mirror of the heart Jālāl al-Dīn Rūmi records the following: "It is the banquet of the Emperor of Rum-so polish our hearts, that we may become rustless like the mirror of the spirit!" Chittick 1983, 322; "The Forgiving God desired and decided in eternity to reveal and manifest Himself. But no opposite can be displayed without its own opposite, and that peerless King had no opposite.

So He made a vicegerent, a Possessor of the Heart, to be the mirror of His Kingship.

Then He gave him limitless purity...In a similar manner, Abel came in the second period: Opposed to his pure light was Cain..." Jālāl al-Dīn Rūmī Mathnawi VI. 2151-2157. William Chittick writes of these lines, "Adam in his "limitless purity" became a mirror for God's Attributes, i.e., the archetypes of all existence, are reflected within him. So all knowledge and all things were to be found within his breast".

"The saint's own bodily form has been annihilated and he has become a mirror; within it are reflected the faces of others.

If you spit, you spit in your own face; if you strike the mirror, you strike yourself.

If you see an ugly face, that is you; and if you see Jesus and Mary, that is you.

He is neither this nor that, he is plain; He has set your own reflection before you". Jālāl al-Dīn Rūmi Mathnawi VI. 2140-2143.

89 Jālāl al-Dīn Rūmī Fîhi Mâ Fîhi 50.

90 Addas 1993, 283.

91 For Ibn 'Arabi's description of the Perfect Man, Adam, Ibn Arabi Fusus al-Hikam 98-99.

92 Aflaki Manaqeb al-arefin III. 95.

93 Holy Qur'an Sürat 66:4 “...then lo! Allah, even He, is his (Muhammad's) protecting Friend,...". It is noteworthy in respect to the title of Emir Jālāl al-Dīn Qaratā'ī, Vali Allah fi'l-ard, the friend of Allāh on earth (eg. Ibn Bibi II. 103), that Jālāl al-Dīn Rūmī employs the phrase "the Four Friends", to describe the first four Caliphs: "The Justice of God hath mated every one (with one of his own kind)-elephant with elephant and gnat with gnat. 
led by Jālăl al-Dīn Rūmi. The intention being to attain to that profound comprehension of the Almighty given to the Prophet Sulaymān, as similarly to Al-Khidr, "and taught him a knowledge from Our own" ${ }^{\prime \prime}$, to reach a station elevated over discursive knowledge and wisdom, hence the location - position and choice of the two types, Qur'anic and hadith inscriptions on the portal, in the relative prominence in position of these inscriptions on this entrance portal. Consequently the explicit inscriptions on the entrance portal of the Qaratā'i Madrasa can be read as an implicit statement of this hierarchy of knowledge, that of the outward, and that of the inward, resembling that between As-Zahir - The Outward and Al-Bartin - The Inward, as is clear in the difference in the designs employed on the exterior and in the interior of this madrasa, as also providing visual record of the need for both, one confirming the other, as "there is no firm dividing line between Sufism and traditional scholarship" ${ }^{\prime 5}$.

In transit from this world, through the Externals of Faith towards a Polished Heart

There is a clear difference expressed in the explicit inscriptions deployed on the exterior facade of this madrasa, distinct from those around its doorway, and from those in the interior of the building, marking and defining the transition from the work of intention and prayer in this temporal world, transiting through the doorway of the externals, passing into the realm of reflections in the polished heart. The entrance facade carries the expected foundation inscription divided into two texts, one worldly, one relating the prayer of the Prophet Sulaymān, while a little deeper into the substance of the building is the frame to the entrance doorway carrying a series of hadith that not only refer to the educational function of the building, as is noted by the author ${ }^{96}$, but which also serves as a reminder of the external aspects of the faith ${ }^{97}$.

The suggestion the author makes that: "The longest hadith found here introduces what I consider to be a biographical element relating to the founder, an element that continues until the end." ${ }^{98}$, and that, "they (these hadith) add a biographical element to religious inscriptions" ${ }^{99}$, that the choice of ahadith on the lower part of the left hand side of this doorframe was made to present biographical material relating to the Regent and Emir Jālāl al-Dīn Qaratā'î, a permanent record cut in stone concerning the possible worldly concerns of the patron of the building, to be read by the staff, students and guests of this madrasa in this manner, the selection of hadith for autobiographical purposes around the door into a mid- $13^{\text {th }}$ century madrasa, seems to this reviewer, to be unwarranted and unsupported speculation. This, in part, because to have

The familiar associates of Ahmad (Muhammad, literally, "the familiars of Ahmad in the place where people sat together") were the Four Friends (Abu Bakr, 'Umar, 'Uthman and 'Ali)...", (Jālāl al-Dīn Rūmì Mathnawi VI. 1894-1895) and the names of the Four Friends are represented in the cut-tile work on the pendentives supporting the semi-dome of the madrasa.

"a knowledge from Our own", described as: "That immediate intuition (intuitive knowledge) in relation to them is thought, in relation to those who are far (from God) it is vision". Jālāl al-Dīn Rūmī Mathnawi II. 176.

95 Ernst 1994, 123.

96 Redford 2015, 151-152.

97 It was understood by some in the $13^{\text {th }}$ century including Ibn 'Arabī that, "sharī'a or Islamic law and haqīqa or reality are identical, and all spiritual realisation is attained through strict observance of the Law and scrupulous imitation of the Prophet's Sunna". Addas 1993, 270-271. For his different views concerning participation in samā' and his subsequent rejection of it, see Addas 1993, 163-164.

98 Redford 2015, 152.

99 Redford 2015, 153. 
attained the title of Vali Allah fi'l-ard, the friend of Allāh on earth, rather suggests the capacity of the Emir to place worldly matters and the personal (ego), together with temporary passing phenomena in their proper place, rather than publicly committing the transient to posterity through the selection of the hadith carved around the lower part of the left hand side of this doorframe.

The author suggests the choice of one hadith in this section of this doorframe, presented in two parts and reading, "(inna) al-walad mabkhala majbana," - a child is a cause of greed and cowardice -, "may be connected to the political context of Qaratay's regency: the factions surrounding each of the three young brothers of the ruling dynasty in general and the debauched behaviour of the teenaged sultan 'Izz al-Din in particular"100. However, the relationship of the choice of this hadith on this doorway "to the political context of Qaratay's regency... and the debauched behaviour of the teenaged sultan 'Izz al-Din in particular", is, at least to this reviewer, not in the least evident. This hadith seems rather be related to that recorded by Taqi ud- Dīn Abū-l-'Abbas Ahmad ibn 'Abd al-Halim ibn 'Abd as-Salam ibn Taymiyyah (1263-1328), in a chapter entitled, Greed is a cause of slipping into Deviation, a hadith which concerns the nature and expression of parental greed and cowardice towards the Almighty contrasted with the practice of offering one child to the path of Allāh:

"Thus, the Prophet (sas) joined the two types of patience in the following sahih hadith found in the collection of Muslim: "The Prophet said: "How do you define Ar-Raqoob (childless) among you?" They said: "Ar-Raqoob is the one to whom no child has been born." The Prophet said: "That is not Ar-Raqoob, rather Ar-Raqoob is the one who has not offered any one of his children" (i.e. in the path of Allāh)" ${ }^{101}$.

Consequently the reason for this hadith on this doorframe is rather to be understood as reminding parents not to be greedy and cowardly towards the Almighty, but rather, to offer a child in the path of Allāh, to be educated in the religion, as in the Qaratā'î madrasa (and God knows best).

The final hadith around this doorframe reads al-Qur'ān huwa al-dawa $\bar{a}^{\prime}$ - The Qur'an is the remedy - this hadith marking the transition from the external to the internal, rather than closing with this hadith the suggested autobiography of the Emir. Passing through this door, through the vestibule and reaching the interior, one finds a different world.

It would seem that this change was a consequence of the uses the central enclosed area in this madrasa was designed to serve. This was an area in which not only religious-legal teaching took place ${ }^{102}$, but was also the place where the dervish sama $\bar{a}^{\prime}$ was frequently held ${ }^{103}$, some sessions led by Jālāl al-Dīn Rūmī and hosted/attended by the Regent and Emir Jālāl al-Dīn Qaratā'̄i, Vali Allah fi'l-ard, the friend of Allāh on earth, together with other noteworthy guests and events of a related character ${ }^{104}$, which unfortunately are not remarked upon at any length

\footnotetext{
100 Redford 2015, 153.

101 From ibn Taymiyyah's Enjoining Right And Forbidding Wrong, Trans.: S. Morgan, source: http://www.javaman.com/pages/books/alhisba.htmI\#GREED IS THE CAUSE OF SLIPPING INTO DEVIATION (accessed 8-012016).

102 As in the lectures given by Rokn al-Dīn-e Mazandarānī, Aflaki Manaqeb al-arefin III. 494.

103 Aflaki Manaqeb al-arefin III. 95.

104 In addition on occasion to spectacular performances provided in this madrasa by figures such as Sayyedī Taj
} 
by the author of this chapter. Yet it seems evident that the master designers of the Seljuk Palace-State nakkaşhane under the direction of the regent and friend of Allāh on earth, would have certainly have considered this dual function of this space in their choice of designs and decorative motifs and of the explicit and implicit texts to be displayed through the decoration of this interior space.

They produced in consequence of their understanding of the functions this central area of the madrasa was constructed to serve, a world in which the interior world has been transformed into the exterior, an externalised interior vision. At ground floor level a world of glinting gold designs and inscriptions scattered like shath in a samā, with light, sunlight, reflected sunlight, lamplight and candlelight, reflecting off the glazed surfaces of the turquoise coloured hexagonal tile-work revetments, and from the designs and inscriptions in praise of the Almighty.

The glazed surface of the hexagonal tiled revetments covered with geometric and floral designs, some having 6 centres- 6 petals etc., designs covered with applied gold, includes depictions of the 6 pointed seal of Sulaymān - seal of the Prophets device which, as noted above, can be "read" as 'Ahmad' "Because Ahmad's (=the Prophet Muhammad's) name is engraved on his seal"105 and/or read as 'Allāh'; as also inscriptions in applied gold on these hexagonal tiles of two phrases, al-'Izz lillāh, Glory to Allāh and, al-Mulk lillāh, Dominion is Allāh's, and this collection of phrases sounds like zikrullāh, Allāh, al-'Izz lillāh, al-Mulk lillāh. The latter phrase can be understood, like al-'Izz lillāh, as being in praise of the Almighty, because it reminds in a shortened form of the first Ayat of Sürat Al-Mulk 67:1, 'Blessed be He in Whose Hand is the dominion." ${ }^{106}$, the importance of which was made explicit by the Prophet Muhammad, as "Imam Ahmad recorded from Abu Hurayrah that Muhammad said, 'Verily, there is a chapter in the Qur'an which contains thirty Ayat (the Sürat Al-Mulk) that will intercede on behalf of its reciter until he is forgiven. (It is): Blessed be He in Whose Hand is the dominion. This Hadith was collected by At-Tirmidhi and the four Sunan Compilers" ${ }^{107}$. As is the case with the prayer of Sulaymān on the portal, "My Lord! Inspire me to give thanks for Your blessing...", both of these inscriptions: al-'Izz lillāh, al-Mulk lillāh also remind of the praise due to the Almighty. The author of this chapter however writes concerning the use of the phrase al-Mulk lillāh that, this "phrase is used so often in Seljuk Anatolia that it is not outlandish to propose it as the religious motto, or one of the mottos or devices, used by the Seljuk sultans as a signature." ${ }^{108}$, providing a rather different characterisation of one of these texts praising the Almighty.

\section{On the names in the Turkish Triangles below the dome}

Concerning the names recorded in kufi script filling the 20 pendentives in the four Turkish triangles in the zone of transition to the dome the author writes:

"This writing consists of names of prophets and caliphs. Ascending, as they are, they can be viewed as being in an intercessory position between the human and the

\footnotetext{
al-Dīn b. Sayyedı Ahmad al-Refa'ī and a group of dervishes, see Aflaki Manaqeb al-arefin V. 16.

105 Schimmel 2001, 191, SD 167.

106 As also: Holy Qur'an Az-Zumar 6; Holy Qur'an Al-Mala'ikah 13.

107 Source: http://www.qtafsir.com/index.php?option=com_content\&task=view\&id=1297

108 Redford 2015, 155.
} 
divine, but the arrangement of names also argues for a temporal progression from Abrahamic prophets through Muhammad to the Rightly Guided Caliphs... Muhammad had(sic) a prominent role in Islam, mystical or not, as an intercessor, so his prominence in the inscriptional program of the fan pendentives comes as no surprise...According to Islamic belief, Muhammad intercedes with God on behalf of believers on Judgement Day. In this sense, the prominence of intercession as a theme of the inscriptional program of the Qaratay Madrasa can be thought of as chosen for a structure that houses the tomb of its patron, who was advanced in age when it was being built, and died soon after its completion" ${ }^{109}$.

The problem with the title given to this chapter, as also of the passages from it cited above, is that there is no evidence concerning intercession presented by the author, nor evidence to show that the inscriptional program of the madrasa and of the tomb-turbé were/are related in this exceptional way. The author produces no evidence to confirm the assertion made that intercession was in fact a prominent theme of the inscriptional program of this madrasa. Not noted as intercessory by the author are the inscriptions on these hexagonal tiles reading alMulk lillāh, which would probably been read as such, but on behalf of whom? Presumably on behalf of the reader, not on behalf of the Regent and Emir, as there is no indication that this was the case. Beyond these, there seems no explicit epigraphic evidence for intercession as a theme or as a specific series of examples. The presence of the repetition of names in the pendentives provides no evidence for any 'ascending' as such, nor does the presence in these pendentives of the name of the Prophet Muhammad itself provide any certain evidence in respect to the suggested theme of intercession.

Concerning Shafa'ah - intercession in the mid-13 ${ }^{\text {th }}$ century, the author writes in his conclusion, "According to Islamic belief, Muhammad intercedes with God(sic) on behalf of believers on Judgement Day." ${ }^{110}$, and that, "Jalal al-Din Qaratay can be seen as playing a dual intercessory role: as a patron in building the building, but also as a saintly man, as God's friend on earth revealing through his actions knowledge of God to others, just as did the prophets and caliphs in the past. In turn, he relied on the Prophet Muhammad to intercede with God on his behalf on Judgement Day". It is somewhat surprising to find the author describe Jālāl al-Dīn Qaratā'î's 'dual intercessory role', as being due to the fact that he was the patron of this building and through, "revealing through his actions knowledge of God to others, just as did the prophets and caliphs in the past", as neither of these actions would seem to have the particular characteristics more usually associated with the term intercession - the act of pleading to Allāh on behalf of another, made by an intimate friend of Allāh (a Muslim saint such as the Regent

109 Redford 2015, 162-164.

110 Concerning intercession: Holy Qur'an Sürat 6: 51, "Warn hereby those who fear (because they know) that they will be gathered unto their Lord, for whom there is no protecting friend nor intercessor beside Him, that they may (ward off) evil"; Holy Qur'an Sürat 6: 70, "...Remind mankind hereby lest a soul be destroyed by what it earneth. It hath beside Allah no friend nor intercessor, and though it offer every compensation it will not be accepted from it". In respect to those given leave to intercede by the Almighty, see: Holy Qur'an Sürat 2: 255, "Who is he that intercedeth with Him save by His leave?" Holy Qur'an Sürat Saba 23, "No intercession availeth with Him save for him whom He permitteth". As likewise Holy Qur'an Sürat Al-Najm 26, "And how many angels are in the heavens whose intercession availeth naught save after Allah giveth leave to whom He chooseth and accepteth!" my emphasis. 
and Emir Jālāl al-Dīn Qaratā'î, given his title of Vali Allah fi'l-ard, the friend of Allāh on earth) and, although it is known from the contemporary sources that all of the names in the zone of transition below the dome were quttb ${ }^{111}$, were understood in the $13^{\text {th }}$ century to have the capacity, by leave of the Almighty, to intercede with Allāh on behalf of Muslims ${ }^{112}$, not solely on the Day of Judgement in the "Shafa'ah al-Uzma" (the Great Intercession), there is no evidence presented to indicate that the names in these triangles were so positioned in order to serve any intercessory function. There is every possibility, given the troubles of the latter part of the $13^{\text {th }}$ and $14^{\text {th }}$ centuries that petitioners visiting the tomb of this Vali Allah fi'l-ard, the friend of Allāh on earth, pleaded in prayer for his intercession with the Almighty for the easing of all manner of difficulties consequent upon Pagan Mongol over-lordship, famine, warfare, extortion, chaos and distress, but there is no evidence presented to suggest this subsequent practice had any precedent based upon the mid- $13^{\text {th }}$ century inscriptional program of the madrasa, and there is insufficient surviving epigraphic evidence to suggest this was the case for the tomb-turbé ${ }^{113}$. Consequently, quite how, "the general avoidance of explicit statements here and the use of placement, programme and epigraphic style as clues to meaning.", permits the author to assert, "the prominence of intercession as a theme of the inscriptional programme of the Qaratay Madrasa can be thought of as chosen for a structure that houses the tomb of its patron, who was advanced in age when it was being built, and died soon after its completion"114, is entirely unclear. It appears "the prominence of intercession as a theme of the inscriptional programme" is an unsupported assertion, based solely upon the presence of the founders' tomb within the madrasa.

The arrangement of the names in these Turkish triangles is complex (Fig. 2), providing in a sequence such as: Īsa, Abū Bakr, Īsa, Muhammad, Abū Bakr, Mūsā, a somewhat less than obvious "temporal progression from Abrahamic prophets through Muhammad to the Rightly Guided Caliphs"115. The author relates that the four Turkish triangles - "fans", (each composed of five pendentives, each pendentive containing in cut-tile mosaic the repetition of a single name in Kufi script, except for one which contains two names), "presents prophetic history, quite naturally in such a setting, from an Islamic point of view. This point of view is expressed within each single triangle, as well as in the overall scheme governing all four of the triangles"116. And, "As we have seen, the temporal succession (or completion) of Abrahamic prophets

\footnotetext{
111 Redford 2015, 164.

112 As for example: "If it see the Light of God, what is there to grieve about? How little are two eyes (to him that is) in union with God! And if it shall not see God, let it go! Let such a miserable eye become blind! Do not grieve for your eye when that Jesus is yours; do not go to the left (but to the right), that he may give you two right (sound) eyes. The Jesus of your spirit is present with you: beg aid from him, for he is a goodly aider; But do not every moment lay on the heart of (that) Jesus the unprofitable work of (providing for) a body full of bones...Seek not from your Jesus the life of the body, ask not from your Moses the wish of a Pharaoh. Burden not your heart with thoughts of livelihood; livelihood will not fail: be (constant in attendance) at the (Divine) court". Jālāl al-Dīn Rūmī Mathnawi II. 447-454.

113 Redford 2015, 166.

114 Redford 2015, 163-164.

115 Redford 2015, 163.

116 Redford 2015, 157.
} 
The 21 explicit names recorded in kufi script in the Turkish triangles beneath the dome

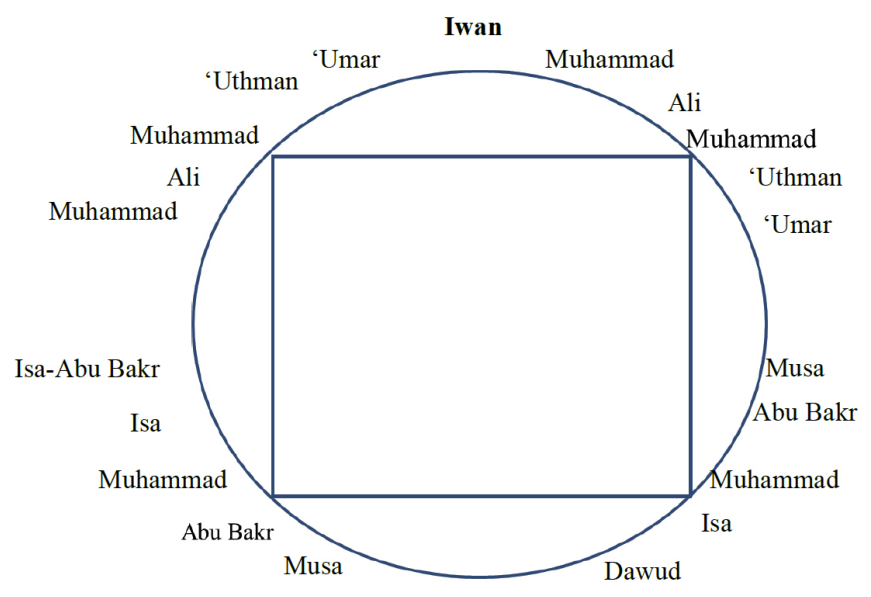

Fig. 2

Prophet Muhammad then continues with caliphs"117. The problem with this is firstly that prophetic history, Islamic or other, is hardly presented through the repetition of a single name on each of these 19 pendentives and one pendentive that contains two names (IIsa and Abū Bakr), and, more particularly, because only 8 different names are spread over these 20 triangular surfaces, and because half, four of these eight names, are not those of prophets but are those of the first four Caliphs. Consequently to state we are presented with Islamic prophetic history, yet the Prophet Ibrahim-Abraham amongst others is unmentioned, seems somewhat inadequate as an explanation. This, not least, because the defining characteristic of the four named prophets is that they were not only prophets - nabi - of which there are a large number known and unknown, 25 are mentioned by name in the Holy Qur'an, but that they were also messengers - rusul, which is the reason why they are named in these pendentives. Of these eight names, four are the names of rasul, who are also by definition prophets, and four are the names of the first four caliphs.

Further, there certainly was a wide variety of Islamic points of view concerning prophetic and other history in the $13^{\text {th }}$ century, as is the case today - there was, and there is, no monolithic "Islamic point of view" - and so, for the author to state, "This point of view is expressed within each single triangle," seems to be most strange. How exactly is the reader supposed to understand this so-called Islamic point of view of "prophetic history (sic)" expressed within each single triangle - when looking at the 5, and in one case the 6 names in each triangle? For example, the five names repeated on the triangle to the left of that over the door, reads from right to left: Dāwūd, Īsa, Muhammad, Abū Bakr and Mūsā. The author must have a strange view of Islamic "prophetic history (sic)", or of any other kind of history, to see the name of the Prophet Mūsā, understood to have lived c. 1500-1400 B.C., given after the name of the first Caliph who died in 634 A.D. on this triangle, and to describe this as the "Islamic point of view" of prophetic history, as though the summit of revelation was reached by the Prophet Mūsā.

The distribution of these names was deliberate, planned. At the four corners of the square

117 Redford 2015, 157. 
within the circle is the name of the Prophet Muhammad (Fig. 2), not noted by the author. Muhammad stands, the figure at the beginning and at the end in the sequence of Abrahamic Prophets, hence the seal of Prophethood:

"That is why the Prophet, possessor of a myriad virtues, spoke the mystery, "We are the last and the foremost": "Although in form I am born of Adam, in meaning I am the ancestor of my ancestor. For the angels prostrated themselves to him for my sake, and he followed me to the seventh heaven" ${ }^{118}$.

One half of the incomplete circle of names, those on the triangles on either side of the iwān, are the names of Islam, those of the Prophet Muhammad and three of the first four caliphs, the name of the first caliph is represented, although implicitly rather than explicitly (see below). Reading from right to left, the triangles on either side of the iwān carry the same names in the same order: the Caliph 'Umar, the Caliph 'Uthman, the Prophet Muhammad, the Caliph 'Ali, the Prophet Muhammad, with the last three of the caliphs given in historical order: 'Umar, 'Uthman and 'Ali, while the name of the Prophet Muhammad is repeated twice in this sequence of names, in the middle, as is the case for all four triangles, indicating the centrality and summation of the Abrahamic cycle of revelation brought by this prophetic messenger, and once, at the end of the sequence of names in these two triangles on either side of the iwān.

Reading in historical sequence the names on either side of the iwān, the Prophet Muhammad and the second Caliph 'Umar, the name implicitly of the iwān space is therefore that of the first Caliph Abū Bakr, noted for his love of God and friendship with the Prophet Muhammad (see below). In consequence of the name of the first Caliph Abū Bakr, implicit, of the iwān, there are two full historical sequences of the name of the Prophet Muhammad and the names of the first four caliphs (Fig. 3). The first is that which begins with the name of the Prophet Muhammad to the right of the iwān and concludes with the name of the Prophet Muhammad recorded on the left hand side of the triangle with its point above the entrance to

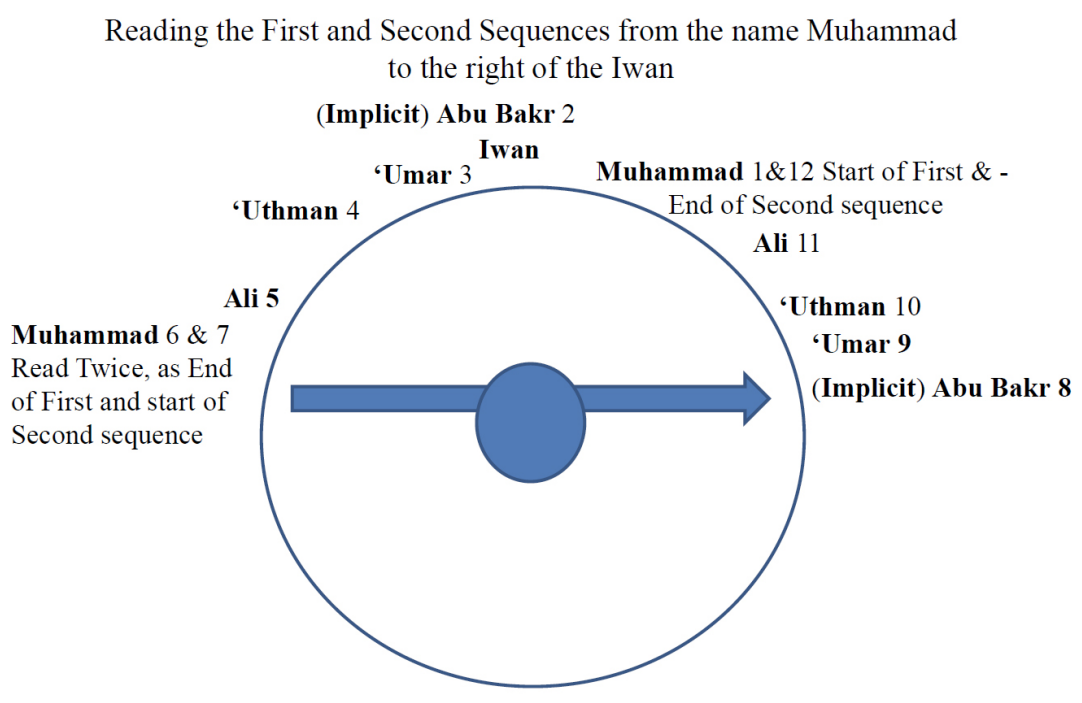

Fig. 3

118 Jālāl al-Dīn Rūmī Mathnawi I. 526-528. 
the tomb chamber of the founder, the Regent and Emir Jālāl al-Dīn Qaratā'̂̃. The sequence of names is: Muhammad, (Abū Bakr-implicit), 'Umar, 'Uthman, Muhammad, 'Ali, Muhammad, beginning and ending with the name Muhammad. The second of the three times the name Muhammad occurs, it is in consequence of having the name Muhammad at each corner of the square, recorded in the central pendentive of each triangle (Fig. 2).

Jâlāl al-Dīn Rūmì (1207-1273) employs the phrase "the Four Friends", to describe the first four caliphs, the Rāshidun, or "Rightly Guided" caliphs, who all knew the Prophet Muhammad:

"The Justice of God hath mated every one (with one of his own kind)-elephant with elephant and gnat with gnat.

The familiar associates of Ahmad (the Prophet Muhammad, literally, "the familiars of Ahmad in the place where people sat together") were the Four Friends (Abu Bakr, 'Umar, 'Uthman and 'Ali)..."

And so, perhaps in this respect it seems worth recalling that the religious title of the Regent and Emir Jālāl al-Dīn Qaratā'î, the patron of this building, was recorded as, Vali Allah fi'l-ard, the Friend of Allāh on earth, and so, the Friend of Allāh on earth, is implicitly joined to the names of The Four Friends and to the name of the Prophet Muhammad repeated three times, at the beginning, towards the end, and at the end of this sequence of names, over the entrance to the tomb chamber of the founder of the madrasa. There is also, through their shared presence in absence, an implicit relationship drawn between the first Caliph Abū Bakr's name, not explicitly recorded on the îwān and the Regent and Emir Jālāl al-Dīn Q Qaratā'î, un-named, but implicit (Fig. 4).

The implicit names beneath the dome

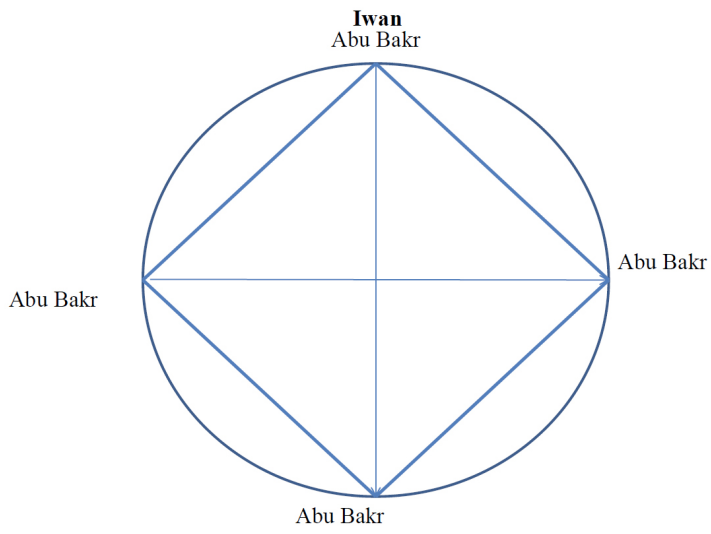

Fig. 4
The Silent (implicit) link: Abu Bakr

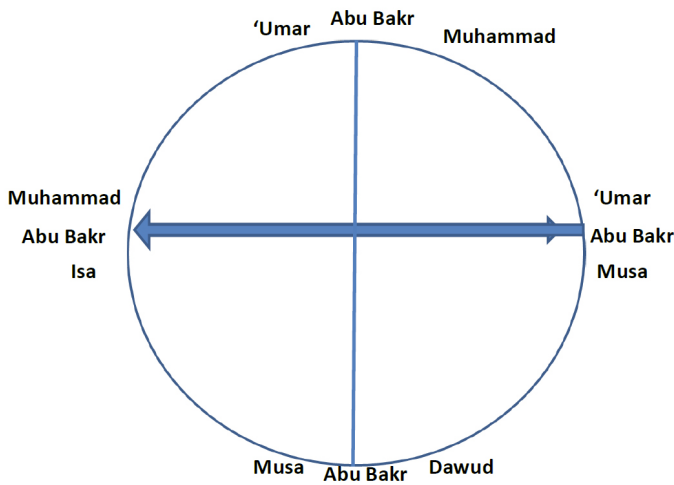

Fig. 5

It is the case with this cycle of names in the transition zone below the dome that the implicit, if un-named Abū Bakr's presence on the iwān, is the most powerful and important epigraphic statement made, and yet, it is not written. It is there by implication, understood even if unlettered, and to be 'read' as such in consequence of the names to either side of it, and is all the more powerful for this, its presence in absence (Fig. 5).

The prominence of the name of the Prophet Muhammad in this transition zone, recorded on 6 pendentives, on the central pendentive of the five pendentives forming the Turkish triangles

119 Jālāl al-Dīn Rūmī Mathnawi VI. 1894-1895. 
in each of the four corners, and in marking off the area of the iwān and the entrance to the tomb chamber of the founder, although not noted by the author in this chapter, is evident, and was certainly intentional. In marking the area of the iwān and the entrance to the tomb chamber of the founder, through the name of the Prophet Muhammad at the start and end of this historical sequence of names, shows the Prophet and Messenger, Muhammad, as is understood by followers of Islam, to be both the first and also the last, that is in an intercessory role for Muslims at the end of time, as well as the beginning and end of the Abrahamic sequence of Prophets, of the People of the Book, of learning and of return to origin, that is, of the înān and the tomb.

Reading the Sequence of names marking the square of Muhammad

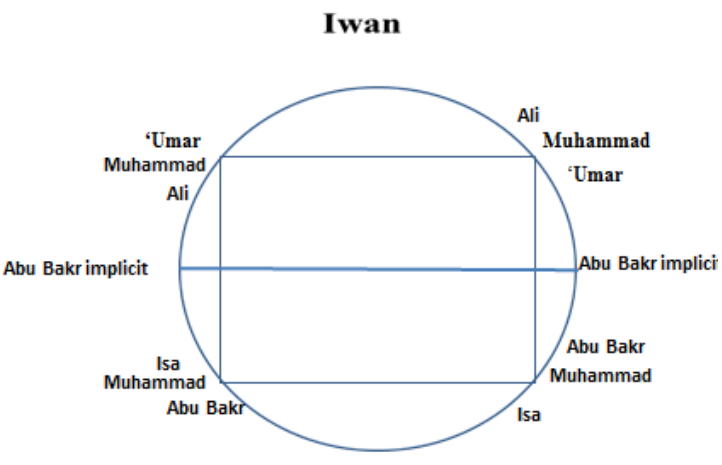

Fig. 6
Reading the Sequences by the square of Muhammad

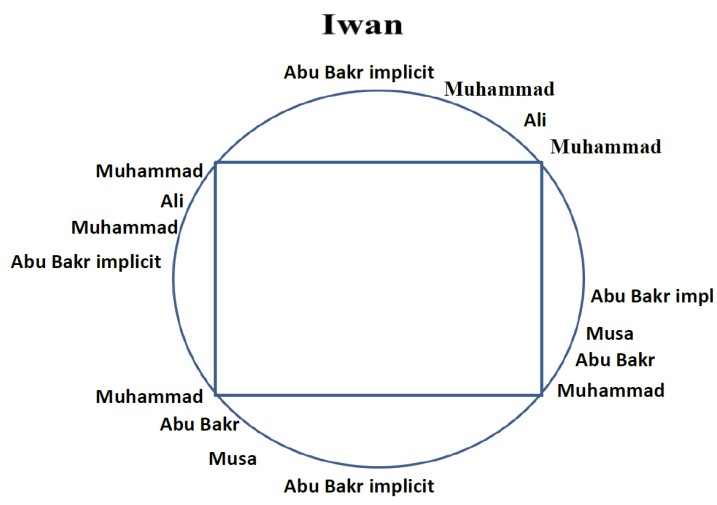

Fig. 7

This semicircle consists of the repeat of these two sequences of names. Within these sequences there are two further sequences of names: one of three names and one of four within these two name sequences of 6 and 7 names that begin and end with the name Muhammad. That sequence recorded in the centre of the triangles either side of the iwān, where the name of the third Caliph 'Uthman is followed by the name of the Prophet Muhammad, followed by the name of the fourth Caliph 'Ali, out of historical order: 'Uthman, Muhammad, 'Ali, centred on the square within the circle defined by the name Muhammad (Fig. 6); and the sequence consisting of the last two names in the historical sequence, Muhammad and 'Ali, followed by the name Muhammad repeated, this marking both the end of the sequence and also the start of the next, together with the second name of the 7 name sequence, Abū Bakr (silent-implicit) (Fig. 7). The four names of this sequence read: Muhammad, 'Ali, Muhammad, Abū Bakr (silent-implicit). The reasons for the combination of Muhammad with both 'Ali and Abū Bakr are mentioned below. The combination of the 3 name and the 4 name sequences around the four 'Muhammad' marking the corners of the square within the circle, provides 4 sets of 7 names. The 7 is of importance as a number reminding of the " 7 oft repeated verses" of the Fatiha, Qur'an Surāt Al-Hijr, 15:88, as likewise Jālāl al-Dīn Rūmī in the Divan Shemsi Tabriz relates, "The senses are the 5 prayers, but the heart is the 7 verses" ${ }^{120}$. The name "Umar is not mentioned in either of these two "secondary" sequences repeated on both sides of this semicircle.

120 Jālāl al-Dīn Rūmī Dîvâni Shemsi Tabrîzi XLIV, for the 7 verses see also, Jālāl al-Dīn Rūmī Dîvâni Shemsi Tabrîzi VI. 
The second 7 name sequence begins from reading for a second time the name Muhammad that ends the first sequence, crosses the width of the space, from Abū Bakr-implicit to Abū Bakrimplicit on the facing wall, 'Umar, 'Uthman, Muhammad, 'Ali, Muhammad (to the right of the iwān, where the first sequence begins again) (Fig. 5).

The other half of the circle of names, those in the semicircle facing the iwān (Fig. 8), consist of the name of the Messenger of Christianity, the Prophet İsa and the names of the Jewish Messengers, the Prophet Dāwūd and the Prophet Mūsā, together with the names of the Prophet Muhammad and the first Caliph Abū Bakr. Both sequences of this semicircle are likewise centred around a sequence of three names. Reading from right to left: the name of the Prophet İsa, then the name of the Prophet Muhammad, followed by the name of the first Caliph Abū Bakr, with the name Muhammad at the centre of both triangles of this semicircle. Different from that sequence of three names, reading from right to left, recorded in the centre of the triangles either side of the iwān, where the name of the third Caliph 'Uthman is followed by the name of the Prophet Muhammad, followed by the name of the fourth Caliph 'Ali. Noteworthy is the linking of two of the Messengers' names İsa and Muhammad with the first Caliph Abū Bakr. Matching the sequence of 4 names in the first semicircle, there is the sequence of 4 names Muhammad, Abū Bakr, Mūsā and Abū Bakr, silent-implicit.

Reading the Third and Fourth sequences Musa to Musa

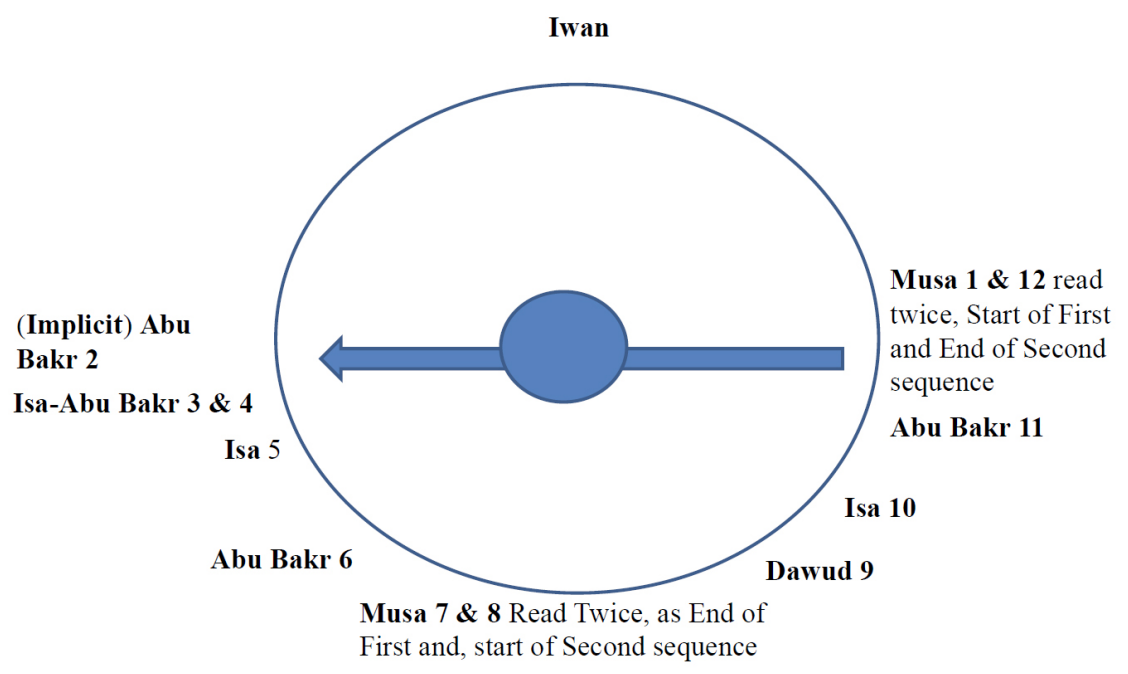

Fig. 8

Continuing reading from right to left, the names recorded on the other two triangles are those of: the Prophet Īsa, the Caliph Abū Bakr (both on the same pendentive), the Prophet İsa, the Prophet Muhammad, the Caliph Abū Bakr, the Prophet Mūsā (these on the triangle with 6 names), the Prophet Dāwūd, the Prophet Īsa, the Prophet Muhammad, the Caliph Abū Bakr and the Prophet Mūsā on the second triangle.

The 6 names in 5 pendentives in the triangle over the door read: Īsa, Abū Bakr, Īsa, Muhammad, Abū Bakr, Mūsā. If one continues reading, as with the name Muhammad to the right of the iwān, with the last name of the previous triangle, Muhammad, being the first of the subsequent sequence, it would read: Muhammad, Abū Bakr (silent-implicit), İsa, Abū Bakr, Īsa, Muhammad, Abū Bakr, Mūsā, which ends, if the sequence end with the same name, in the 
second Muhammad before the iwān and this makes little sense. However, there is the gap between the two triangles, Abū Bakr (implicit), and there is a clear distinction in content between the two semicircles of names. Consequently reversing the way from Muhammad to Abū Bakr (implicit) to Abū Bakr (implicit) to 'Umar, of the first semicircle, the third sequence should, it is suggested, being with Mūsā, crossing from Abū Bakr (implicit) to Abū Bakr (implicit) to İsa. So the third sequence should begin by reading the name Mūsā, Abū Bakr (implicit) recrossing the width of the space to the facing wall, to Abū Bakr (implicit), İsa, Abū Bakr, Īsa, Muhammad, Abū Bakr, Mūsā (these on the triangle with 6 names), with the name Mūsā read twice, as the end of the third and as the beginning of the fourth sequence, Mūsā, Abū Bakr (implicit), Dāwūd, Īsa, Muhammad, Abū Bakr and Mūsā, where the fourth sequence ends and the third begins again, Mūsā being read twice, as the name Muhammad is read twice in the first and second sequences.

It is a sequence that begins with the name Mūsā and concludes with the same name. The name of the Prophet Muhammad after the name of the Prophet İsa and followed by the name Abū Bakr, indicating the succession and also the name Muhammad here marks a corner of the square marked by the name Muhammad, within the circle of the names of the four MessengerProphets and the first four caliphs.

The final-fourth triangle carries in sequence read from right to left the names: Dāwūd, İsa, Muhammad, Abū Bakr and Mūsā, which, following precedent, should be preceded by the last name in the previous triangle, that of the Prophet Mūsā and so reading: Mūsā, Abū Bakr (implicit), Dāwūd, İsa, Muhammad, Abū Bakr and Mūsā, the sequence beginning and ending with the Prophet Mūsā. Abū Bakr (implicit) in the space between the names Mūsā and Dāwūd.

\section{On the Seal of the Prophets}

There is the space between the names Mūsā and Dāwūd, as in the three other spaces of this same type. It is suggested here that silent but implicit in these spaces, to be read as an implicit text, is the name of the first Caliph Abū Bakr. This is almost certainly the case for this space, not least because it would face the name of Abū Bakr (implicit) on the facing iwān and complete the representation of "the best of all men after the prophets" in the horizontal four of the six directions ${ }^{121}$, thereby forming a square within the circle of names implicitly recording the name Abū Bakr, like the square in this same circle that explicitly records the name of the Prophet Muhammad. In consequence it is evident that through the combination of these two squares within the circle, that of the name of the Prophet Muhammad explicit, and that of the first Caliph Abū Bakr implicit, within this circle of names, an implicit representation of the seal of the Prophets - seal of Sulaymān device, that with 8 points is formed (Fig. 9), that stretches implicitly over the whole area beneath the dome.

It is of note that the seal of the Prophets - seal of Solomon device with 6 points depicted on the hexagonal tile revetment of the walls beneath this zone of transition with these triangles, has at the centre a series of three dots ${ }^{122}$, while at the centre of this construct in the mind, of

121 For example: Jālāl al-Dīn Rūmī Mathnawi VI. 4; IV. 1811 and III. 3108.

122 The 3 dots, within this seal of 6 points, in this context would seem to require investigation, as also if it is related to the meaning carried by the three dots of the so-called 'shah-i benek-cintimani' device employed on works of Islamic design, as in works of medieval astrology-astronomy Heaven is represented by the 
The sequence of implicit and explicit names in the zone of transition below the dome with the

8-pointed seal

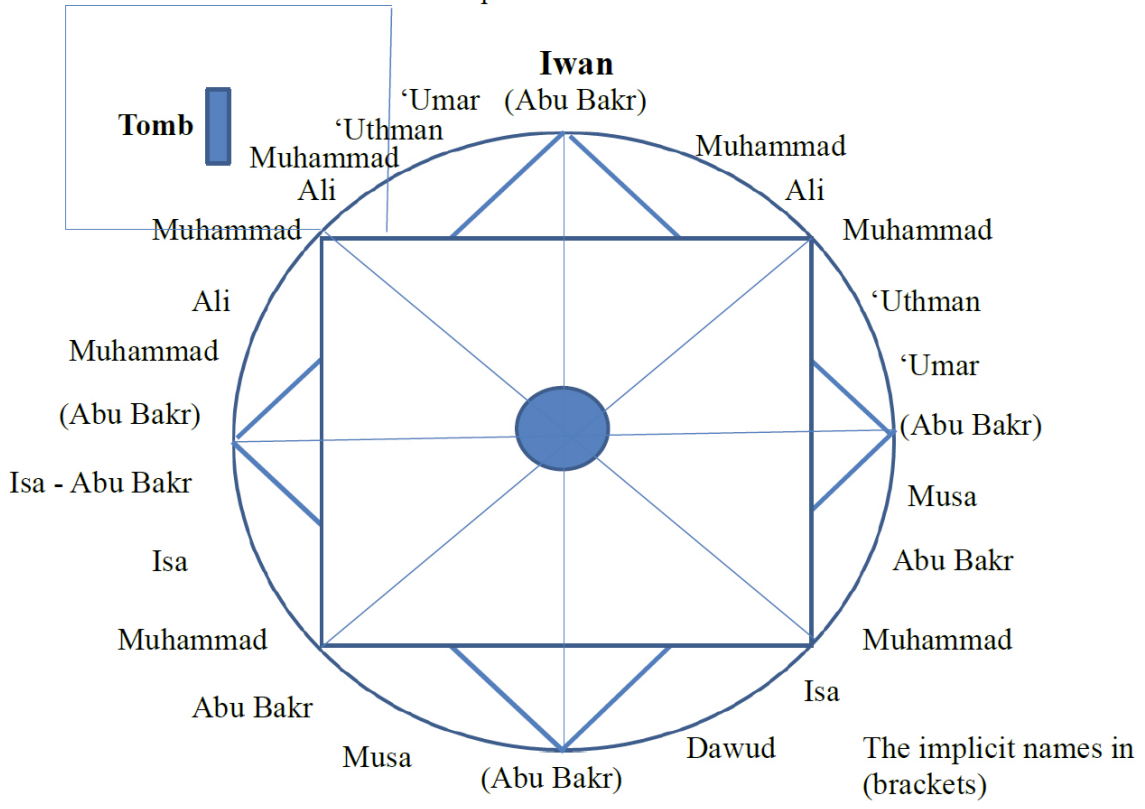

Fig. 9

this seal with 8 points, there is the single light flooding down from the oculus, a visual reminder of the nür-i ilähi, of the Light and of the One.

There is a poetic reminder of the process involved in this work undertaken by a nakkash of re-expressing through design, recorded by Hakim Jamal al-Dīn Abu Muhammad llyas b.Yusuf b. Zaki b. Mu'ayyad Nizam ud-Dīn of Ganja (1140/1-ca.1208/9) in his Haft Paikar, concerning the "7 oft repeated verses" of the Fatiha and the dot:

"If seven lines converge, a single point at last falls on the target of the affair. The painter who has ten subservient parts holds to the end of every single thread $^{\prime 123}$.

And a further example of the necessary focus upon numbers for a nakkash, as also for understanding this way of working comes in some lines of a poem by Khwāja Ahmad Yasavĩ:

"My Maker I'll seek in this universe by night and day;

From the four directions of space I have been torn away.

Let me go from four to seven; one by one to nine I count.

In Saturn's sphere, from two on up to ten I've made my way;

Three hundred and sixty the rivers I crossed, the mountains four hundred and forty four" ${ }^{124}$.

When realising the 8 points of this implicit seal one may reflect upon the 8 produced by the

number 3. There are numerous groupings of three, including that of Angels, Men and Beasts (creatures), described by Jālāl al-Dīn Rūmī Fîhi Mâ Fîhi 17.

123 Nizâmî-i Gencevi Haft Paikar 166-167.

124 Shushud 1983, 14, citing from Khāzinīs Jawāhir al-Abrār. 
sum of the letters forming the word Yasin, of the Holy Koran Sūrat, Yasin, provides the number 134 and, 134 is also the numerical equivalent of the name Samed - Samet دصص, which is one of the Names of the Almighty, meaning the Eternal, the Most High and is a word 'samad' in, and at times, used to name the Sūrat Al-Ikhlâs/Samad/at-Tawhid - Oneness-The Eternal-The Unity ${ }^{125}$, 112.2 of the Holy Qur'an. Thus the word, Yasin is, in this sense, the equivalent of Samed and $1+$ $3+4=8$ and, in consequence the eight points of this seal can be understood thereby to represent-symbolise Unity.

The ratio of the 4 different names beside the name Muhammad at the four corners of the square within the circle: 4:2:2:2:2, respectively: Muhammad 4, Īsa 2, Abū Bakr, 2, 'Uthman 2, 'Ali 2.

The ratio of the 5 different names beside the implicit name Abū Bakr at the four corners of the square within the circle: 4:2:2:2:1:1, respectively: Abū Bakr 4, Muhammad 2, 'Umar 2, Mūsā 2, Dāwūd 1, İsa 1.

Sum of the ratio of names including those of Muhammad and of Abū Bakr (implicit) at the 8 points: 6:6:2:2:2:3:1:2, Muhammad 6, Abū Bakr 6, 'Umar 2, 'Uthman 2, 'Ali 2, İsa 3, Dāwūd 1, Mūsā 2.

As noted earlier, it is a matter of the combination of the Explicit and the Implicit, in a sense, resembling As-Zahir - The Outward and Al-Bartin - The Inward, as likewise in the dhikr of negation and affirmation, and it is this that one may be reminded of, when this implicit seal of the Prophets -8 pointed seal of Sulaymān device is realised as being both implicitly present and absent at this level above the tiled revetments, covering the entire area beneath the dome, that is, within the symbolism employed, this eight pointed seal of the explicit Muhammad and the implicit Abū Bakr covers from above the maydān for dhikr, that is, the universe, the entire the whole world.

To summarise:

The four points of the explicit square within the circle of names are marked by the name of the Prophet Muhammad. The name of the Prophet Muhammad in the centre of the triangles on either side of the iwān is preceded by the name of the third Caliph 'Uthman and followed by the name of the fourth Caliph 'Ali; while on the other two triangles, the name of the Prophet Muhammad is preceded by the name of the Prophet Isa, followed by the name of the first Caliph, Abū Bakr. The four points of the square within the circle of names, that carry the implicit name of $A b \bar{u}$ Bakr, which, when combined with the explicit square of the name Muhammad, form the 8 pointed seal of the Prophets - seal of Sulaymān device, with, at its centre the intersection of the names Muhammad and Abū Bakr (implicit), within a circle of light, light flooding through the oculus, visual reminder of the Light of the Almighty nūr-i ilāhi.

The sequence of names beginning from the name Muhammad to the right of the iwān reads: Muhammad, Abū Bakr (implicit), the second Caliph 'Umar, the third Caliph 'Uthman, the Prophet Muhammad, marking a corner of the square in the circle, the fourth Caliph 'Ali, the Prophet Muhammad, with the sequence of 7 names ( 1 implicit), beginning and ending with the

125 In transliteration: Bismillah ir-Rahman ir-Raheem 1. Qul huwa Allah hu ahad 2. Allah hu 's-samad 3. Lam yalid wa lam yulad 4. Wa lam yakun lahu kufuwan ahad. 
name of the Messenger Prophet, Muhammad.

The next sequence of names reads: Mūsā, Abū Bakr implicit to Abū Bakr implicit, Īsa, Abū Bakr, Īsa, Muhammad marking a corner of the square in the circle, Abū Bakr, Mūsā, the sequence of 9 names, (2 implicit), beginning and ending with the name Mūsā.

The next sequences of names reads: Mūsā, Abū Bakr (implicit), Dāwūd, Īsa, Muhammad marking a corner of the square in the circle, Abū Bakr and Mūsā, the sequence of 7 names (1 implicit), beginning and ending with the Prophet Mūsā.

The final sequence of names reads: Muhammad (read also in the first sequence), Abū Bakr (implicit) to Abū Bakr (implicit), 'Umar, 'Uthman, Muhammad, 'Ali, Muhammad. This sequence of 8 names, ( 2 implicit), begins and ends with the name Muhammad (read also as the first in the first sequence).

The four names heading and closing these four sequences, containing a total of 25 names some read twice, a total of 31 explicit and implicit names, are respectively: Muhammad and Muhammad and, Mūsā and Mūsā, while the first Caliph, Abū Bakr, has his name implicit on the iwān and in the other three gaps between the triangles, and the design clearly suggests the importance of the name Abu Bakr. It is of course upon these two sets of names, both the explicit and implicit, that the inscription band around the base of the dome carrying the Ayet from the Sürat I-baqarah, The Cow, 2:255 (The Throne Ayet) and 2:256 rests.

The repetition of the same name on more than one pendentive, as also implicitly, may suggest emphasis and so indicate a contextually relevant, relative importance, and if this is regarded, the result in respect to these 21 explicit and four of these names read twice $=25$, and 4 implicit names, 2 read twice, a total of 31 names, is quite interesting: the Prophet DāwūdDavid 1, the Prophet Mūsā-Moses 2 with them read twice = 4, the Caliph 'Umar 2, the Caliph 'Uthman 2, the Caliph 'Ali 2, the Prophet İsa-Jesus 3, the Caliph Abū Bakr $3+4$ implicit with 2 read twice $=9$, and the name of the Prophet Muhammad is repeated on 6 of these 20 pendentives, with two read twice, $=8$.

While the total number of names, $31=3+1=4$, which is represented by the Arabic letter, dâl. There are numerous associations that can be made within this context with the number 4 : The 4 Books: Torah, Psalms, Gospels and Qur'an, and the Four Messengers; The Four Archangels, The 4 Angels supporting the Throne; The four contained in the Lord of the two Easts and the Lord of the two Wests, Allāh ${ }^{126}$; The 4 Gardens of Paradise ${ }^{127}$ and the 4 Rivers of Paradise of honey, milk, water and wine; The 4 Sacred Months of the year ${ }^{128}$ : Muharram, the first month in the calendar, Rajab, the seventh month, Dhu'l $Q a^{\prime} d a$, the eleventh month and Dhu'I Hajja, the twelfth month; The four stages to the pilgrimage, $8^{\text {th }}-10^{\text {th }}$ Dhu'l-Hijja: The Departure for Arafat, The Standing on Arafat, The Day of Sacrifice and, The Journey to Mina; The Four Righteous Caliphs.

Simply put, we are not presented with 'Islamic Prophetic history', we are presented with the names of four Prophet - Messengers, Mūsā, Dāwūd, Īsa and Muhammad and, implicitly thereby,

\footnotetext{
126 Holy Qur'an Sūrat Al-Rahman 17.

127 Holy Qur'an Sūrat Al-Rahman 46, 65.

128 Holy Qur'an Sūrat Al-Tawbah 36.
} 


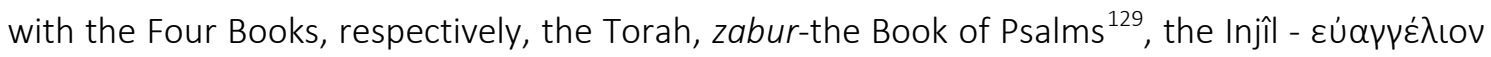
- the books of the four Evangelists, and the Qur'an - al-furqan, with a respective relative emphasis of $2: 1: 3: 8$ (6 explicit, two read twice $=8)$; together with the names of the first four Caliphs after the death of the Prophet, the Rāshidun, or "Rightly Guided" caliphs, al-Khiläfah arRāshidah, the Caliphs 'Umar, 'Uthman and 'Ali, each with 2 pendentives and the Prophet Muhammad's immediate successor, the Caliph Abū Bakr, with 3 pendentives +4 implicit +2 implicit read twice, the 9 fold repetition of his name.

These 31 names of which 21 are explicit, two of the name Muhammad are read twice, and two of the name Mūsā are read twice, and four implicitly with the name Abū Bakr with two of these read twice, giving a total of 10 implicit, are divided equally into two groups, with these groups linked through the name Abū Bakr.

The group of 13 names, reading: Muhammad (the right of the iwwān,), Abū Bakr (implicit), 'Umar, 'Uthman, Muhammad, 'Ali, Muhammad, Abū Bakr to Abū Bakr (implicit in the space between the facing triangles), 'Umar, 'Uthman, Muhammad, 'Ali, (to Muhammad read twice) (Fig. 9).

\section{Noteworthy in this sequence of 13 names is:}

Firstly, that this inner circle of names is a repeat, both sequences beginning and ending in the name Muhammad.

Secondly, the name on the iwān arch is implicitly the name Abū Bakr, and, in this silsila from Muhammad through the first four caliphs to Muhammad doubled, the two instances where the name Abū Bakr is to be expected, it is not recorded explicitly but is implicit, it is to be read in, rather than read over, present in the space.

Thirdly, the name Muhammad is repeated 4 times, due to the presence within this sequence of two of the four mentions of the name Muhammad marking the four corners of the square within the circle and to the fact that the name Muhammad is in two cases is both the end and the beginning of the silsila and so is read 6 times.

Fourthly, there is the most remarkable way that the implicit name of Abū Bakr on one side of this domed space then extends to the other side beneath the light from the oculus to connect with the implicit name of Abū Bakr opposite.

Fifthly, there is the sequence of the names Muhammad, 'Ali, Muhammad on both sides of the îwān arch with the implicit Abū Bakr; Muhammad, 'Ali, Muhammad, Abū Bakr.

Sixthly, there is the sequence of names on either side of the name Muhammad marking the corners of the square in this semicircle: 'Uthman, Muhammad, 'Ali

Lastly, the ratio of names $3: 3$ implicit : $1: 1: 1$, in this sequence is doubled to form the complete semi-circle of names within the circle: Muhammad 6, Abū Bakr 6 (implicit), 'Umar 2, 'Uthman 2, 'Ali 2.

The group of 15 names forming the other semicircle reads: Mūsā, Abū Bakr (implicit) to Abū Bakr (implicit), Īsa, Abū Bakr, Īsa, Muhammad, Abū Bakr, Mūsā, Abū Bakr (implicit), Dāwūd, Īsa,

129 "Your Lord knows whoever is in the heavens and the earth. We exalted some of the prophets over the others; and to David We gave the Book of Psalms". Holy Qur'an Sūrat Al-Isra 55. 
Muhammad, Abū Bakr, Mūsā (Fig. 9).

Noteworthy in this sequence of 15 names is:

Firstly, that it comprises two different sets of names linked by the name Mūsā to form the semicircle of names, each segment beginning and ending with the name Mūsā, the sequence read after that of the revelation of the Holy Qur'an, being the Injîl-İsa, followed by the zabur, the Book of Psalms- Dāwūd and finally the Torah, Mūsā. Both of these sets of names separated and joined by the implicit name of Abū Bakr on either side of the hall.

Secondly, as in the first sequence, the name Abū Bakr (implicit) mirrors in the second sequence, in the most remarkable way that the name of Abū Bakr (implicit) on one side of this domed space extends to the other side beneath the light from the oculus, except in the reverse direction; instead of Muhammad, Abū Bakr (implicit) to Abū Bakr (implicit), to 'Umar, it reads: Mūsā, Abū Bakr (implicit) to Abū Bakr (implicit) to İsa. Both chains of names pass through Abū Bakr.

Thirdly, unlike in the first group of 14 names above, the name Abū Bakr is recorded explicitly 3 times, twice in the İsa sequence and once in the Mūsā-Dāwūd sequence, as well as the name Abū Bakr being recorded three times implicitly; while the name Muhammad is repeated twice, once in the İsa sequence and once in the Mūsā sequence, due to the presence within these sequences of two of the four mentions of the name Muhammad that mark the four corners of the square within the circle and indicate the centrality of Muhammad.

Fourthly, there is the sequence of names on either side of the name Muhammad marking the corners of the square in this semicircle: İsa, Muhammad, Abū Bakr. The names beside the square of Muhammad within the full circle are: Muhammad, 'Ali, Abū Bakr, 'Uthman and İsa and the frequency of these names produce a ratio of: Muhammad 4, 'Ali 2, Abū Bakr 2, 'Uthman 2, and Īsa 2.

Consequently the ratio of names in these two sequence of 9 and 7 names can be read: Mūsā 2 , İsa 2, Abū Bakr 4, Muhammad 1; Mūsā, 2, Abū Bakr 2, Muhammad 1, İsa 1, Dāwūd 1. With the total for the semicircle: Abū Bakr 6 (3 + 3 implicit), İsa 3, Muhammad 2, Mūsā, 2+2 = 4, Dāwūd1.

On the importance of 'Abdallāh bin Abī Quhāāah aș-Ṣiddīq for the Seljuk Regent and Emir Jālāl alDīn Qaratā'î

The importance given to the names of the four Rashidun $(9+6$ implicit $=15)$ in comparison to the names of the four nabi - rusul ${ }^{130},(12+4$ repeats $=16)$, is evident, perhaps more evident than one might have expected, $15: 16$, due to the prominence within the names of the four Rāshidun of the name of the first Caliph Abū Bakr, 'Abdallāh bin Abī Quhāāah aș-Ṣiddīq.

A part of the reason why the name Abū Bakr is recorded 9 times, 3 explicitly (the same number as the Prophet İsa) and 6 implicitly, with two read twice, which is therefore a name which occurs more frequently than any other name, the name Muhammad is named 6 times explicitly and read 8 times, and, more frequent than the total occurrences of the names of the other three "Rightly Guided" caliphs, a ratio respectively of, $9: 2: 2: 2$; was due in part to the three days the Prophet and Abū Bakr spent together in refuge in a cave on Mount Thaur by

130 In the Holy Qur'an the names of these four Messenger - Prophets occur with a completely different frequency, Mūsā is named 136 times, Dāwūd 16, Īsa 29 and the name Muhammad a total of 4 times. 
Mecca ${ }^{131}$, and to the importance attributed to this. This transmission of interior knowledge to Abū Bakr, which seems to be represented through the 8 names on the 8 points of the seal of the Prophets in this design (4 explicit Muhammad and 4 silent-implicit Abū Bakr), is recorded in a well-known hadith:

"The Angel Gabriel was the Guide of the Prophets and the Prophet was the Guide of the Companions. As the Prophet awaited revelation (Wahy), so the Companions awaited guidance from the Prophet. Before the Prophet left corporal life he perfected his training of Abu Bakr As-Siddiq, according to the Hadith: "Everything that Allah poured into my heart. I have poured into the heart of Abu Bakr"132, and thus was he able to provide guidance for the whole Ummah. When the Muslims of that time made the oath of allegiance (Bay'ah) they were, in effect, recognising Abu Bakr as the one through whom Divine Guidance would come to them - that they wouldn't act according to their personal whims and opinions in opposition to his orders.

Allah Almighty has never allowed for a generation to pass - from the time of Abu Bakr on - without the Inheritor of the Holy Prophet being able to complete his training of one to succeed him in carrying the trust of guiding true seekers to the truth. This is the meaning of the Qur'anic Verse: "And follow the Path of he who has turned his heart to $\mathrm{Me}^{\prime \prime 133}$. What it means is that we must follow our Guide the way that the Companions followed the Prophet - and they followed the Prophet like the Prophet followed Gabriel"134.

There is further reason. In the Two Sahihs, it is recorded that Abu Sa'id Al-Khudri said that when the Messenger of Allāh gave then his last speech, he said:

'O People! If I were to take a Khalil (an intimate friend) from the people of the earth, I would have taken Abu Bakr bin Abi Quhafa as my Khalil. However, your companion is the Khalil of Allah'135.

Jâlāl al-Dīn Rūmì provides further probable reason why the name of the Abū Bakr occurs explicitly and implicitly so frequently, in addition to the widely held Sunni belief that Abū Bakr is the best of all men after the prophets - he cites a famous tradition:

"'Abū Bakr was not deemed your superior on account of much praying and fasting and almsgiving, but on account of something that was fixed in his heart.' The Prophet says that Abū Bakr's superiority over others was not by reason of much praying and fasting, but because God's special favour was with him, namely the love of God. On the resurrection day when men's prayers are brought, they will be put in the balance, and likewise their fasting and almsgivings; but when love is

\footnotetext{
131 Ibn Ishaq Al-sīra al-Nabawiyya 71.

132 Hadīth recorded by Suyuti in, al-hawi li-l-Fatawa, as by Bukhāri in his Sahih. As likewise with the addition of the name Umar, translated as: "Allah has expanded my breast for what He has expanded the breast of Abu Bakr and Umar to receive".

133 Holy Qur'an Sürat Qāf 37 "Verily in this is a Message for any that has a heart and understanding or who gives ear and earnestly witnesses (the truth)".

134 Ad-Daghistani 1982, 20.

135 Abdul-Rahman 2009, 119.
} 
brought, it will not be contained in the balance. So the root of the matter is love"136.

It can be understood that in part, it is as a representative of this love of the Almighty by one who was not a prophet but was a Righteous Ruler that provides the reason for the prominence of Abū Bakr in this circle of names, and in particular emphasised by his name implicit on the iwān and in the third sequence that begins and ends with the name Mūsā and which includes the names of the Prophet Īsa twice ${ }^{137}$, Muhammad once, and the name Abū Bakr four times, twice implicit. The emphasis upon Abū Bakr, an early, perhaps the first male convert to Islam, can in part, be read as an indication of the role of the saint-pole on earth after the Last of the Prophet's, Muhammad, until the end of days, as Jālāl al-Dīn Rūmī relates:

"(Now), as the grandeur of the Prophet has become established, none feels envy (of him), since he is accepted by all the Faithful);

Therefore in every epoch (after Muhammad) a saint arises (to act as his vicegerent): the probation (of the people) lasts until the Resurrection.

Whosoever has a good disposition is saved; whosoever has a glass heart is broken.

That saint, then, is the living Imam who arises (in every age), whether he be a descendant of 'Umar or of 'Ali.

He is the Mahdi (the God-guided one) and the Hadi (the Guide), O seeker of the (right) way: he is both hidden (from you) and seated before your face. (such is the case with the name Abū Bakr amongst these names, both explicit and implicit)

He is the Light (of Muhammad), and (Universal) Reason is his Gabriel; the saint that is lesser than he is his lamp (and receives illumination from him).

That (saint) who is lesser than this lamp is our lamp-niche: the Light has gradations in degree" ${ }^{138}$.

There is a hadith that seems to draw the same distinction that is drawn between the Prophet Muhammad and the Prophet Mūsā through this sequences of names recorded below the dome, with the dividing line extending from the implicit name of Abū Bakr to the implicit name of Abū Bakr across the width of the hall separating it beneath the dome into two halves, one half the Muslim semicircle centred on the îwān, the other its precursors provided by the Prophets Mūsā, Dāwūd and İsa: "Muhammad Ibn al-'Alấ' told us that Ibn Numayr reported from Mujâlid from Ibn 'Aamir from Jâbir that 'Umar Ibn al-Khattâb brought a copy of the Torah to the Prophet and said: "O Apostle of God, this is a copy of the Torah." But [the Prophet] kept silent. Then 'Umar started reading and the face of the Prophet kept changing. So, Abu Bakr interrupted him violently: "Don't you see the face of the Prophet?" "Umar looked at the Prophet's face and said "May God preserve me from His anger and from the anger of his Apostle, we accepted God as Lord and Islâm as religion and Muhammad as prophet." Then the Prophet said: "By the One Who

136 Jālāl al-Dīn Rūmī Fîhi Mâ Fîhi 60 (222, 274).

137 "Except at night there is no unveiling of the moon: except through heartache do not seek your heart's desire. Forsaking Jesus, you have fostered the ass: of necessity, like the ass, you are outside of the curtain. Knowledge and gnosis are the fortune of Jesus; they are not the fortune of the ass, O you asinine one!" Jālāl al-Dīn Rūmī Mathnawi II. 1849-1851.

138 Jālāl al-Dīn Rūmī Mathnawi II. 814-820. 
owns Muhammad's soul, if Moses appeared to you and you followed him and left me, you would go astray from the right path and if he were alive and reached [the time of] my prophethood he would have followed $m e^{\prime \prime 139}$.

In addition there is the early account related by Ibn Ishaq concerning the Prophet Muhammad and the Prophet Mūsā in heaven, concerning the number of prayers per day for the new Muslim community, the Messenger relates that Mūsā-Moses 'was a good friend to man.' This hadîth records the initial fifty was appealed at the prompting of Mūsā, and was finally reduced by the Almighty to five: "This lasted until they arrived in the seventh heaven, where the apostle met his Lord, who made fifty prayers incumbent upon him.

The apostle of Allah continued his story. 'Then I began my return. When I passed near Moses, who was a good friend to man, he asked, "How many prayers have been made incumbent upon thee?" and I replied, "Fifty prayers every day." Moses said, "Prayer is heavy, and thy people are weak. Go to thy Lord and ask Him to lighten it for thee, and for thy people." Accordingly I returned to my Lord and asked Him to alleviate it for me and my people. And He deducted ten. I went away again and passed near Moses, who repeated what he had said before. So I returned and asked my Lord, who once more deducted ten; and I went back to Moses, who sent me many times with the same injunction, until so many prayers were deducted that only five prayers remained for each day and night. On this last occasion, when I returned to Moses, he repeated his words once more, but I said to him, "I have gone back to my Lord and asked Him so many times that I am ashamed; therefore I shall do it no more." Nevertheless, whosoever among you recites these five prayers, believing wholly in their efficacy and validity, will receive the reward due for the fifty prayers originally prescribed ${ }^{\prime 140}$.

In consequence of the above inquiry into this sequences of names, one can perhaps best characterise the choice of names and of their relative emphasis within this area of transition below the dome, as expressing the Sunni understanding of the matter of Right Guidance and Righteous Rulership, with certain emphasis upon the Prophet Muhammad and a slight emphasis upon the Prophet İsa, not therefore a particularly surprising collection of names and of emphasis in respect to a Sunni madrasa of the Hanafi madhhab - except for the absence of Khalil Ibrahim-Abraham - this due to the selection of the Messengers rather than Prophets, and the relative prominence of the Prophet Mūsā ${ }^{141}$, and for the most considerable emphasis, both explicit and implicit (silent), upon the name of the first Caliph Abū Bakr, an emphasis more than that given to the name of the Prophet Muhammad, a ratio of names respectively of $9: 8$ (3:6 explicit and, $4+2$ name read twice $=6: 2$ implicit), with the implicit focus of the 8 pointed seal on the combination of the names of the Prophet Muhammad explicit and of the first Caliph Abu Bakr implicit.

A further layer of related meaning is obtained if one adds together the number of times these two names Muhammad and Abū Bakr are mentioned, as a section explicit with the name repeated, or implicitly named within this circle of names, $8+9=17=1+7=8$ which,

139 A hadîth recorded in Abū Bakr Muhammad b. Ahmad al-Sarakhsī's, Usūl, as also: Sunan al-Dârimî Concerning the Prophet Moses, source: http://www.islamic-awareness.org/Quran/Tafseer/daarimi.html

140 Ibn Ishaq Al-sira al-Nabawiyya 63; Sahih al-Bukhari vol. 4, 54, no. 429.

141 Jālāl al-Dīn Rūmī Mathnawi II. 1720-1877, provides a clear contemporary picture of the example provided by the Prophet Mūsā. 
represented as a letter rather than a number, is $h \bar{a}$, the last letter of the Name Allāh, "we lose ourselves in $(h \bar{a})^{\prime} H^{\prime}$ with every breath we blow.", with this letter being the focus of the Kubrāwiyya zikr-dhkir ${ }^{142}$, that is, of hūsh dar dam (see below) ${ }^{143}$. There is also the matter of the importance given to the number 8 itself at this time, that of the 'Four Books' and the four rasulMessenger-Prophets, a total of 8; but also of the 8 Angels that will carry/support al-'Arsh, the Throne of the Almighty on the Day ${ }^{144}$; but, perhaps as importantly for the nakkash-designer, the 8 principles which had been established by the $13^{\text {th }}$ century not only in the so-called, "way of Junayd" ${ }^{145}$ an 8 fold path incorporated into the 10 fold path of the Kubrāwiyya; but also in the 8 principles of the Path of the Khwājagān-the Masters (of Wisdom): hūsh dar dam, nazar bar qadam, safar dar watan, khalwat dar anjuman, yādkard, bāzgasht, nigāhdāsht and yāddāsht ${ }^{146}$, together with the practice of internalised silent zikrullah ${ }^{147}$, zikr-i hafi which, it is suggested here, seems to be the reason for the implicit (silent) mentions of the name Abū Bakr, as in the pair of squares at right angles within the circle, where the name Muhammad is explicit and that of Abū Bakr implicit (silent), names which together form the implicit 8 pointed shamsa-sun-seal of these two names; as also the implicit line drawn across the hall between the silent-implicit name of Abū Bakr and the silent implicit name of Abū Bakr on either side, as also at right angles to this, defining both the centre beneath the dome and the diameter of the circle between Mūsā, Dāwūd and Īsa, the Jewish and Christian Messengers and implicitly, the Books they brought, from the semicircle of the Qur'an and its Messenger Muhammad (Fig. 10).

Further, in this reading of the inscriptions in this zone of transition between the square, the four corners of the world, and the circle of the heavens, it seems the intent of the nakkassdesigner was to draw attention, at this level, to the point where the four explicit names of the Prophet Muhammad intersect with the four implicit names of the first Caliph Abū Bakr, at the point in the centre of the circle of the heavens where the light descends vertically, the point of intersection of the vertical and horizontal, between The Light and the world and the point of intersection of the Four Books, the Light of the Word.

It is evident that the Seljuk Regent and Emir, Jālāl al-Dīn Qaratā'ī, held Abū Bakr in the highest respect and, as the, "Lord of the Ascetics, qutb ${ }^{148}$ - Pole of the Believers, Master of the

142 "The adept (of the Kubrāwiyya ) will learn that the Greatest Name of God is Allāh, or rather the $\mathrm{h}$ at the end of this word". Schimmel 1978, 256.

143 Shaikh Najm al-Dīn al- Kubrā (1145-1220), of the letter of connections between worlds, wāw, also related that, "The ' $h \bar{a}$ ' in the Divine Name Alläh is the very sound we make with every breath". Shushud 1983, 25.

144 Holy Qur'an Sürat Al-Hâaqqah 17.

145 The "way of Junayd" the eight fold path of: "Constant ritual purity, constant fasting, constant silence, constant retreat, constant recollection of God, and constant direction of a sheikh who explains the meanings of one's dreams and visions. Finally one must give up resistance to God's decree and refrain from prayer for reward in the otherworld", Schimmel 1978, 255.

146 For this see for example: Ter Haar 1999, 311. Hosh dar Dam (Consciousness in breathing) (ii) Nazar bar Qadam (Carefulness in movement) (iii) Safar dar Watan (Movement in residence) (iv) Khilwat dar Anjuman (Solitude in the assembly) (v) yādkard (remembrance) (vi) bāz-gasht (restraint) (vii) nigāh-dāsht (watchfulness) (viii) yād-dāsht (recollection); for further on these 8 aphorisms composed by Khwāja 'Abd alKhāliq see, Shushud 1983, 25-26.

147 For the relationship between Al-Khidr (Khizir) and Khwāja Abū Ya'qūb Yūsuf Hamadānī (d.1140) concerning the silent dhikr-zikr, see for example, Ter Haar 1999, 315.

148 Jālāl al-Dīn Rūmì relates concerning the qutb, "Unlike the Qutb (supreme saint) of the age, the possessor of 
The implicit and explicit names in the zone of transition below the dome forming the 8-pointed seal

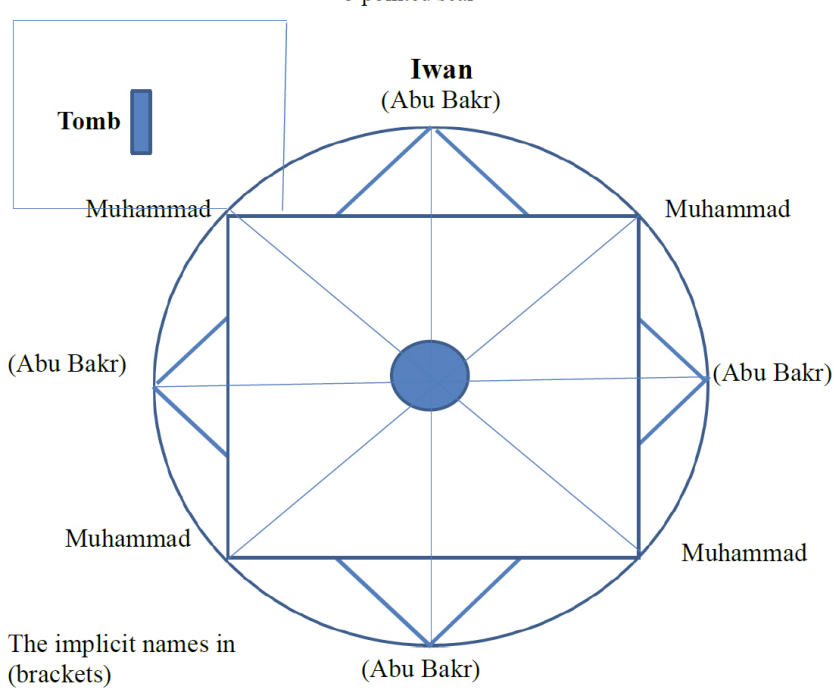

Fig. 10

Emirs and Saints, Crown of the Sufis"149, some of his titles recorded in the waqfiyya - foundation document for this madrasa, it seems reasonable to suggest that this respect was in part due to his association with, perhaps leadership of, and support for those Sufis who did not trace their descent only from the fourth Caliph 'Ali, but instead also traced their decent via the first Caliph $A b u \bar{B} B a k r{ }^{150}$. It seems evident from the distribution of, and the names recorded, both those explicit and the silent-implicit within this zone of transition that the Seljuk Regent and Emir Jālāl al-Dīn Qaratā'i followed the Path of the Khwājagān-the Masters ${ }^{151}$, and he may also have been a leader of the related Suhrawardī order, as the importance of the founder of the Suhrawardi order for Jālāl al-Dīn Qaratā’i is clear, not only from their meeting in 1221, but also from the fact

(spiritual) vision, by whose steadfastness the mountain is made giddy-headed (amazed)", Jālāl al-Dīn Rūmī Mathnawi I. 2129.

149 Turan 1948, 130.

150 Being the only Path that gives its silsila as stemming via Khwāja Abū Ya'qūb Yūsuf Hamadānī (d.1140) and Abū'l-Hassan Kharaqānī (963-1029) from both 'Ali and Abū Bakr, (eg. Makamat-i Nakşibendiyye silsila and the Risâle-i Bahâ'iyye, Shushud 1983,8) as is evident from the distribution of, and the names recorded and implicit in this zone of transition. The precursors of those who were later described by 'Abdu'rahmān Jāmi (d. 1492): "The Naqshbandiyya are strange caravan leaders / who bring the caravan through hidden paths into the sanctuary (Haram)." Schimmel 1978, 364. Also noteworthy in respect to design is the description of the Khwājas, "This people (tāifa) polish the exterior of their minds and intellects with pictures and being free from the rust and wiles of life are not of those who are captivated by the vain colourings of the world, as varied as those of the changeful chameleon; and as Naqshband drew incomparable pictures of the Divine Science, and painted figures of the Eternal Invention, which are not imperceptible, his followers are become celebrated by the title of the Naqsh-bandīs, 'The Painters'”. Brown 1968, 142. Bahā' al-Dīn Naqshband who gave his name to this Path d. 791/1389, added three further principles to the eight already established by the $13^{\text {th }}$ century, the eight it is suggested which are reflected in this design in the Qaratā'i Madrasa for this reason, amongst others.

151 It is unclear if the viziers that were appointed by Jālāl al-Dīn Qaratā'ī, Najm al-Dīn Nakhjavānī, 'Izz al-Dīn Muhammad Rāzī, and perhaps also Baba Tuğrai, were also followers of the same Path and were likewise as strongly attached to the Abbāsid Caliph, maybe by way of the Suhrawardi order. 
that Jālāl al-Dīn Qaratā'i paid for the cost of the construction on his death in 1234 in Baghdad of the tomb of Shihāb al-Dīn Abū Hafs 'Umar al-Suhrawardîn' 152 .

Further, it seems worth noting in the attempt to understand the thinking in the mind of the nameless $13^{\text {th }}$ century designer(s) responsible for the making of the plan of this building, its decorative and epigraphic themes and schemes, that the underlying design of this zone of transition, consisting at one level of the two semicircles of names with the dot of light, was probably seen in alphabetic terms ${ }^{153}$ as approximating in shape to that of the letter nun representing The Light-Nūr ${ }^{154}$, mirrored/doubled, and therefore had a combined numerical value of $50+50=100=1+0+0=1=$ the letter Alif, indicating the Almighty Allāh ${ }^{155}$, and that, "Therefore, the alif was the only letter that (it) was absolutely necessary to know, for as Yunus Emre says: The meaning of the four books is contained in one alif" 156 .

One could of course simply note the relative prominence of the name of first Caliph Abu Bakr in relation to the other caliphs, without reading the silent-implicit name of Abū Bakr in the spaces between the triangles, as also of the name of Prophet Muhammad, within this transition zone of inscriptions, note the apparent equivalence in frequency of, and association of, the name Abū Bakr with the name of the Prophet İsa, this, without attempting to enter to some degree at least into the mind-set of the unknown $13^{\text {th }}$ century nakkash-designer(s), so far as such is both possible and practicable, a matter of spiritual and mental comprehension, in the attempt to adduce reasons for the choice of these names and these four sequences of names. The author does neither. Yet it seems evident from the above that in this case, not only is there the characteristic link in Seljuk Royal foundations of madrasa between political legitimacy-rulership and the Shari'a highlighted ${ }^{157}$, but, in the case of the Qaratā'i madrasa in Konya, there is a most particular emphasis upon the name Abū Bakr for reasons that not only relate to temporal ruler-ship, but which can also be associated with a particular Path followed by this temporary ruler who was also characterised as: "Lord of the Ascetics, qutb - Pole of the Believers, Master of the Emirs and Saints, Crown of the Sufis", and which is an emphasis also related through allusion, in the case of the implicit name Abū Bakr repeated four times in the eight pointed Seal of the Prophets, and particularly over the iwan, to both Abū Bakr and to the temporal legitimacy

152 Cahen 2001, 163. His tomb was restored by the Ottoman Sultan Murād IV. upon the conquest of Bagdad from the Safavids in 1638.

153 For two examples of accounts of seeing in terms of letters, one from the $13^{\text {th }}$ century, "Ibn 'Arabi saw the Divine Essence in the shape of a luminous (letter) he, carrying between its two arms the word huwa (He) on a radiant red background.", and a later Naqshbandi meditation on the physicality of letters, of walking round and between them: "He sees the blessed figure of the word Allāh in the color of light written on the tablet of his heart and the mirror of his imagination... Then he will understand himself as opposite to this form or beneath it or at its right or left side, and he should strive to bring himself towards this light...And whenever he finds himself in the middle of the rank of alif and lām, he must proceed and take his place between the two lāms and then walk away from there and bring himself between the lām and the $h$; and with high ambition he leaves this place too and sees himself in the middle of the ringlet of the $h$. At the beginning he will find his head in this ringlet, but eventually he will find that his whole self has found repose in this house and will rest there free from all afflictions and perilous calamities". See, Schimmel 1984, 99.

154 As in the nūrāniyya the detached letters at the start of 29 of the Qur'an Surā.

155 Schimmel 1984, 94-96.

156 Schimmel 1984, 95.

157 Ephrat 2011, 143. 
represented by means of the First Caliph with the Abbāsid Caliph for the Rūm Seljuk Sultanate under Pagan Mongol over-lordship in 1251-2. That is, the empty place implicitly records the name of the First Caliph Abū Bakr and, at this time and in these circumstances, would also remind implicitly of the current holder of the office, the reigning 'Abbāsid Caliph al-Musta'sim (1242-1258) $)^{158}$ and, it can be suggested, this implicit text was a deliberate part of Jâlāl al-Dīn Qaratā'î's efforts, "to maintain and strengthen links with the free Muslim world" 159 under the auspices of the 'Abbāsid Caliphate for the sake of Islam in Anatolia.

\section{"His throne includeth the heavens and the earth,"}

Looking up, past the tiled revetments of the earth, "Consider the lowness of the earth and the loftiness of the sky: without these two (attributes) its (the sky's) revolution is not (possible), 0 such and such." ${ }^{160}$, looking up as into the revolving sky, into the great hemisphere of the dome, the light pouring down through the oculus, "The window determines how much light enters the house, even if the moon's radiance fills the east and the west." ${ }^{161}$, one sees the design in cut tiework of "shamsa-suns" circling around in an ordered measured pattern the circular opening, the primary light source in the madrasa in daylight hours, the descending light the temporal reminder of The Light, nūr-i ilāhi, signified by the letter nun u with a numerical value of 50, at the core of existence, The Light, reflected in the mirror of the Prophet, like the sun and its reflection in the full moon.

Jālāl al-Dīn Rūmī relates, "Light is the First Cause, and every secondary cause its shadow." ${ }^{162}$, and, "The qibla of the Gnostic is the light of union (with God)"163. The light shining down through the oculus, a reminder of The Light's reflection in the Light of the Prophet:

"This (earthly) newness has oldness as its opposite, but that newness (belonging to the world of Reality) is without opposite or like or number.

'Tis' (even) as by the polishing action of the Light of Mustafa (Mohammed) a hundred thousand sorts of darkness became radiant.

Jew and polytheist and Christian and Magian - all were made of one colour by that Alp Ulugh (great hero (meaning the Prophet, Muhammad-Ahmad-Mustafa).

A hundred thousand shadows short and long became one in the light of that Sun of

158 Jālāl al-Dīn Qaratā'î's association with the Abbāsid Caliph's agenda is clear from 1221 with the Caliph alNasir's spiritual advisor and ambassador Shihāb al-Dīn Abū Hafs 'Umar al-Suhrawardī's visit (Cahen 2001, 162-163) and the importance of the founder of the Suhrawardī order for Jālāl al-Dīn Qaratā'î is clear from the fact that he paid for the cost of the construction of the tomb of Suhrawardi on his death in 1234 in Baghdad. A member of the Suhrawardī order Fakhruddin 'Irāqī (d. 1289 Damascus) also spent time in Konya. While 'Umar al-Suhrawardī's meeting with a representative of the Kubrāwiyya order, Najm al-Dīn Dāya Rāzī in Malatya in 1221, Cahen 2001, 164, and then with Jālāl al-Dīn Qaratā'î may indicate a more than accidental connection between the Caliph, and the Suhrawardī and the Kubrāwiyya orders and in this respect it is important to note that these were not really separate orders as each followed the same chain of masters only recently separated, see Walbridge 1999, 333.

159 Cahen 2001, 181.

160 Jālāl al-Dīn Rūmī Mathnawi VI. 1848.

161 Chittick 1983, 10 (Divan 9911).

162 Chittick 1983, 22 (Divan 525).

163 Jālāl al-Dīn Rūmī Mathnawi VI. 1897. 
mystery.

Neither a long (shadow) remained nor a short nor a wide: shadows of every kind were given in pawn to (be absorbed in) the Sun.

But the unicolority that is (everywhere) at the Resurrection is (then) revealed and (made) manifest to the evil and the good (alike);

For in that world ideas are endued with form, and our (visible) shapes become congruous with our (moral and spiritual) qualities" 164 .

The most impressive broad band of cut-tile decoration in the dome is framed by inscriptions in the borders above and below, the upper border the author suggests, being more legible ${ }^{165}$, less entangled, both of which carry the same Ayet from the Surrat I-baqarah, The Cow, 2:255 (The Throne Ayet) and Ayet 2:256:

\begin{abstract}
"Allah! There is no deity save Him, the Alive, the Eternal. Neither slumber nor sleep overtaketh Him. Unto Him belongeth whatsoever is in the heavens and whatsoever is in the earth. Who is he that intercedeth with Him save by His leave? He knoweth that which is in front of them and that which is behind them, while they encompass nothing of His knowledge save what He will. His throne includeth the heavens and the earth, and He is never weary of preserving them. He is the Sublime, the Tremendous. (2:256) There is no compulsion in religion. The right direction is henceforth distinct from error. And he who rejecteth false deities and believeth in Allah hath grasped a firm handhold which will never break. Allah is Hearer, Knower".
\end{abstract}

It seems within the context of the samā attended by Jālāl al-Dīn Qaratā'i Vali Allah fi'l-ard, the friend of Allāh on earth, and of numerous samā held here in the madrasa of the Regent, perhaps the most pertinent sentences in the inscriptions of these two Ayet from the Surrat Ibaqarah around the circumference of the semi-dome are: "He knoweth that which is in front of them and that which is behind them, while they encompass nothing of His knowledge save what He will." And four of the Names of the Almighty: "He is the Sublime, the Tremendous." and, "Allah is Hearer, (Allāh is) Knower." While the distinction in the type of decoration employed, between the hexagonal tile-work revetments on the walls and the broad band of cut-tile work decoration filling the dome can be understood to depict and reflect the understanding of the distinction drawn thereby between the heavens and the earth, "Unto Him belongeth whatsoever is in the heavens and whatsoever is in the earth.", and, "...the heavens and the earth..." Thereby this central space within this madrasa can be understood as representing in a sense the entire world beneath "His throne" - the heavens and the earth.

Within this wide band of decoration that covers most of the dome there are the depictions in cut tile-work of 16 "shamsa-sunburst"-celestial spheres in 4 ranks of 4 , increasing in size with increasing distance from the light source, the oculus of the dome, exhibiting a particular type of geometric perspective (Fig. 11). It may be that the deliberate use of 16 of these devices relates to the use and importance of the number 8 and of the 8 names, of the explicit and implicit of Muhammad and Abū Bakr at the points of the seal beneath the dome, and the 8 times explicit

\footnotetext{
164 Jālāl al-Dīn Rūmī Mathnawi VI. 1860-1866.

165 Redford 2015, 162.
} 


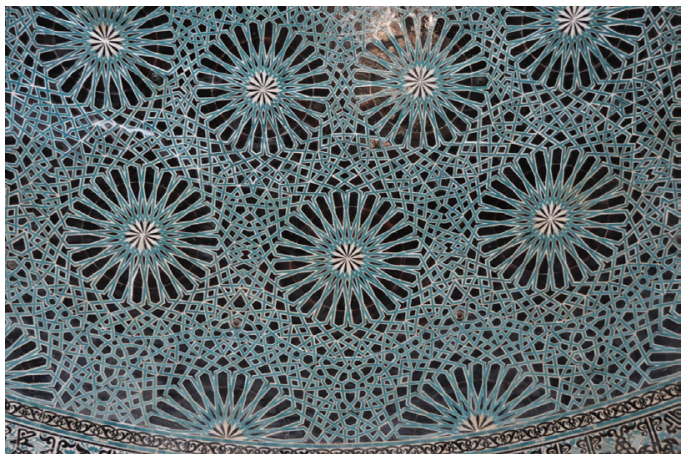

Fig. 11. The heavens in the dome of the Qarata't Madrasa, Konya, some of the 16 celestial spheres depicted in cut-tile work in the dome.

and implicit that the name of Muhammad occurs in the zone of transition below the dome. In the uppermost and lowest ranks of these "shamsasunburst" - celestial spheres they are presented as semi-circular, truncated by the upper and lower borders. Beyond this is the al-falak alatlas, the sky without stars ${ }^{166}$.

Each sunburst-şamsa within each radiating celestial sphere-sun-shamsa ${ }^{167}$ is composed of 12 rays $^{168}$, a complete ray, one half black, the other white, like night and day:

Sūrat At-Taubah 9:36 "Lo! the number of the months with Allah is twelve months by Allah's ordinance in the day that He created the heavens and the earth. Four of them are sacred: that is the right religion." So wrong not yourselves in them.";

Sūrat Yūnus-Jonah 10:6, "Indeed in the alternation of night and day, and whatever Allah has created in the heavens and the earth, there are surely signs for a people who are Godwary."

Sürat Al-Mala'ikah 35:13 "He maketh the night to pass into the day and He maketh the day to pass into the night. He hath subdued the sun and moon to service. Each runneth unto an appointed term. Such is Allah, your Lord; His is the Sovereignty; and those unto whom ye pray instead of Him own not so much as the white spot on a date-stone."

Jālāl al-Dīn Rūmī relates, "The lowness and loftiness of distressful Time are of another sort: one half day and (the other) half night" 169.

The 12 black and 12 white halves of these 12 rays, which can be understood perhaps to represent the 12 months of the year, divided into night and day and, when this total is summed $=24$ and, 2+4=6 reminding of the letter wāw, and implicitly "and (Allāh)" as noted above.

There are further meanings associated with the 12, as, if these rays are understood to represent the 12 months of the year, they implicitly also remind of one of the four sacred months, the $12^{\text {th }}$ month, Dhu I-Hijja, that of the pilgrimage (Hajj) to Mecca.

Was there an implicit meaning to be read, attached to the number 24 , the total number of white and black halves of these rays?

"The Messenger of God (May God bless him and grant him peace) said: The Scriptures [al-suhuf] were revealed to Abraham on the second night of Ramadan,

\footnotetext{
166 Burckhardt 2001, 14.

167 Rather than resembling "the Crystalline Sphere within which God's Throne is located." Aflaki Manaqeb alarefin IV. 54 (449 fn. 42).

168 Resembling in this the similar devices in the cut tile mosaic revetments from the Sırçalı Medrese, Konya of 1242, with examples also exhibited today in the TIEM İstanbul.

169 Jālāl al-Dīn Rūmī Mathnawi VI. 1850.
} 
the Psalms [zabur] were revealed to David on the sixth, the Torah to Moses on the eighteenth of Ramadan, and the Qur'an [al-furqan] to Muhammad (May God bless him and grant him peace) on the twenty fourth of the $9^{\text {th }}$ month, Ramadan (August $10^{\text {th }}, 610$ A.D. $)^{\prime \prime 170}$.

The revelation of the Holy Qur'an is dated to the $24^{\text {th }}$ of Ramadan. It is of note that the sum of the numbers given in this hadith as the dates of revelation to these four Messenger Prophets, $2+6+18+24=50$, the numerical value of the letter $u$ nun, symbol of The Light.

There is also the possibility that they could also be read also as signifying the 24 musical modes, employing quartertones, within each celestial sphere, the music of the spheres:

"When the harpist who plays the four and twenty musical modes finds no ear to listen, his harp becomes a burden;

Neither ditty nor ode comes into his memory: his ten fingers will not get to work.

If there were no ears to receive the message from the Unseen, no announcer (Prophet) would have brought a Revelation from Heaven;

And if there were no eyes to see the works of God, neither would the sky have revolved nor would the earth have smiled (been gay with verdue)"171.

"Were Love not a sama"-lover and tambourine addict, why would I be singing songs like a flute and harp?" ${ }^{172}$.

A total of 16 Celestial spheres ${ }^{173}$ - of worlds encircling the Light, with these Celestial spheres sounding a total of 384 notes simultaneously within this World of the Heavens represented by the dome, and these 384 notes can be read as $3+8+4=1+5=6$ The number 6 reminding of the letter wāw, and implicitly "and (Allāh)" as is noted above.

\section{The matter of intention: "This leaves one final segment with no more Rightly Guided} Caliphs, so it is filled in once again with the name Muhammad"174.

The author writes concerning the names in the pendentives supporting the dome: “...on the southeast triangle (that above the entrance), Muhammad's name is flanked by those of Jesus and Abu Bakr, whereas on the outermost segments, Moses is on one side and, likely due to error, Jesus and Abu Bakr, exceptionally share the same segment. The northeastern triangle is clearer: the name of Muhammad is flanked by those of Jesus and Abu Bakr, with the names David and Moses on the other segments to either side of them." and then, "This leaves one final segment with no more Rightly Guided Caliphs, so it is filled in once again with the name Muhammad"175.

Reading these sentences one may realise the author seems to be working under some misapprehension concerning the methods and means of construction and decoration of

\footnotetext{
170 This hadith was cited by 'Ali ibn 'Asakir, Lindsay 1994, 181; a hadith related by Ibrahim, one of the companions of Abū Abdullah al-Sadiq, is also cited in: Bihar al-Anwar vol. 94, 25, and in al-'Ayyashi's Tafsir vol. 1. 80.

171 Jālāl al-Dīn Rūmī Mathnawi VI. 1657-1660.

172 Chittick 1983, 341.

173 For the celestial spheres and intelligences, see for example, Jālāl al-Dīn Rūmī Mathnawi I. 3955.

174 Redford 2015.

175 Redford 2015, 159.
} 
important Seljuk buildings such as this one, ordered by the Regent, the ruler of the Seljuk state at that time, and constructed in the capital city, where a palace nakkaşhane-design studio was situated.

To write, "and, likely due to error, Jesus and Abu Bakr, exceptionally share the same segment.", and, "This leaves one final segment with no more Rightly Guided Caliphs, so it is filled in once again with the name Muhammad.", gives the reader the impression that perhaps there was no prior thought given as to the designs and texts to be employed, their arrangement, location and size, no considered plans were made, determining for example the specific texts to be employed in the areas that had been allocated for inscriptions, before work began on the construction of this madrasa, as for other structures - suggesting that there really was no overall design, no intention to be expressed in the choices made as to the final appearance of the finished structure. That is, that there were no patterns prepared, that the decoration of surfaces carrying religious texts, both explicit and implicit, proceeded in an ad-hoc manner with "errors", there was no control over the work done, and with the filling in with the name Muhammad due to a suddenly noticed shortage after the passage of five hundred years of Rightly Guided Caliphs - "with no more Rightly Guided Caliphs" - yet in the $13^{\text {th }}$ century you can find clear expression of the thought, of the plan-design, preceding construction. Jālāl al-Dīn Rūmī, well known to the Regent and Emir Jālāl al-Dīn Qaratā'̄, describes in his Fīhi mā fïhi, "The fact that men compose books and set up new skills and buildings is no new composition. They have seen the likeness of that, and merely make additions to it." "176; "So, when you see that from a thought every craft in the world (arises and) subsists -" ${ }^{177}$; as likewise:

"Look on houses and edifices: they were as tales in the (mind of) the architect.

such-and-such a house, which seemed to us beautiful, of which the hall, roof, and door were well-proportioned-

('Twas) the accident (design) and ideas (proceeding) from the architect (that)

Brought the tools and pillars into (into existence) from their respective) handicrafts

... The beginning, which is thought, comes to an end in action"178.

"An architect planned a house in his mind, forming the notion that its breadth would be so much, its length so much, its floor so much, its courtyard so much. People do not call that a 'fancy' since this concrete reality is born from the 'fancy' and is an offshoot thereof. But if someone who is not an architect conceives such a notion and idea in his mind, then people certainly call that a 'fancy.' In common parlance men say of one who is not a builder and has not studied building, 'You are fanciful!'”179.

Perplexingly perhaps, this chapter is entitled: 'Intercession and Succession, Enlightenment and Reflection: The Inscriptional Program of the Karatay Madrasa, Konya', a title that seems

176 Fîhi mā fîhi - what is in it is in it, a quote from Ibn 'Arabi.

177 Jālāl al-Dīn Rūmī Mathnawi II. 1034. "And know, O, brother, that every human craftsman requires a teacher (ustadh) from whom he learns his craft or his science and that his teacher in turn requires a teacher before him and so on until one is reached whose knowledge is not derived from any human being"; Ruggles 2011, 24.

178 Jālāl al-Dīn Rūmī Mathnawi II. 965-970.

179 Jālāl al-Dīn Rūmī Fîhi Mâ Fîhi 26. 
quite at odds with parts of the text in this chapter, with its 'errors' and in-filling of names etc., in clearly implying through the use of the phrase "The Inscriptional Program", that there was both the intention and a program for the explicit inscriptions that were employed in this building, with the employment of explicit inscriptions recording certain texts in certain places being quite characteristic of certain buildings ${ }^{180}$ and structures. It is possible that if the author had thought there was a serious plan to the inscriptions of the Qaratā'i madrasa, the partial solution described above to the sequence of names recorded in the pendentives of the Turkish triangles would have been found, and so the phrase, "likely due to error, Jesus and Abu Bakr, exceptionally share the same segment" would not have been written, as it certainly the case that these names, İsa and $A b \bar{u}$ Bakr, were placed with studied intent on this pendentive, forming a meaningful integral and necessary part of this part of the inscriptional program of the Qaratā'î madrasa.

That plans for architectural and other works were drawn up in the $13^{\text {th }}$ century is recorded, including one drawn by a Seljuk Sultan, recorded by Ibn Bibi: "The Sultan ('Ala' al-Din Keykubat I.) just then give the order to the Emir of the Hunt and architect Sa'd al-Din Köpek to make the palace the same as paradise, in respect to refinement and beauty, to outshine Seder and Havarnak (the fabled palace by Hira of the Sassanid Behram Gur). He drew a shiningly clear and intelligent plan and pointed out its features to the architect...drawing the palace ${ }^{\prime 181}$. Although none are known to have survived with the exception of the designs and construction drawings recorded in the nakkaş Badi' al-Zamman Isma'il ibn Razzaz Abu'l-'Izz al-Jaziri's book, " $A$ compendium of theory and useful practice in the mechanical arts", al-jami bayn al-ilm wa'l-a mal al-nafi fi sin'at al-hiyal, of c.1206, including his design drawing for the bronze door of the Artuqid Palace at Âmid (Diyarbakir) ${ }^{182}$. Yasser Tabbaa describes al-Jaziri's text and drawings as:

"exemplary in their clarity and concision, describing how the design was conceived, the wooden elements cut, and especially how the brass elements were cast into individual shapes. Perhaps most interesting for us is that the author makes a point of describing his pattern as the intersection of two linear systems, hexagonal and octagonal, with various other fillings and incidental shapes between them. He then adds with no little pride that "in this shabaka there are no half or quarter stars nor any incomplete pieces, except for two half stars" ${ }^{183}$.

The suggestion made by the author, of a casual approach to the use of decoration and inscriptions, is also at odds with the contemporary record provided by Ibn Bibi, who not only clearly articulates the importance to $13^{\text {th }}$ century Seljuk taste of coloured designs in his description of the decoration of the tied revetments on the interior walls of the Kubadabad Palace c. 1235, but also describes exactly the type of the decoration to be employed, "The

\footnotetext{
180 Blair 1998, 68-75.

181 There is for example reference made by Ibn Bibi to Sultan 'Ala' al-Dīn Keykubat I drawing the plan of the Kubadabat Palace to be followed in its building by Sa'd al-Dīn Köpek, as noted below and, from the $14^{\text {th }} \mathrm{C}$. for example: "A stone plaque, inscribed with a complex geometric pattern, was also found here (Takht-e Suleyman). Its purpose was at first a mystery; now it is thought to be a plan for the muqarnas vault of Sultan Abaqa's audience hall', Elliot 2006, 206.

182 i̇stanbul T.S.M. Kitaplığı, Ahmet III, 3472, fols. 167r and v. illustrated Tabbaa 2001 fig. 46.

183 Tabbaa 2001, 97.
} 
'kafesli' adorned walls should be so colourful, the colours of the birds in the sky should fade with envy, all laid on with turquoise and blue, so blue, the watchman of the sky should be driven into jealousy" (Fig. 12) ${ }^{184}$.

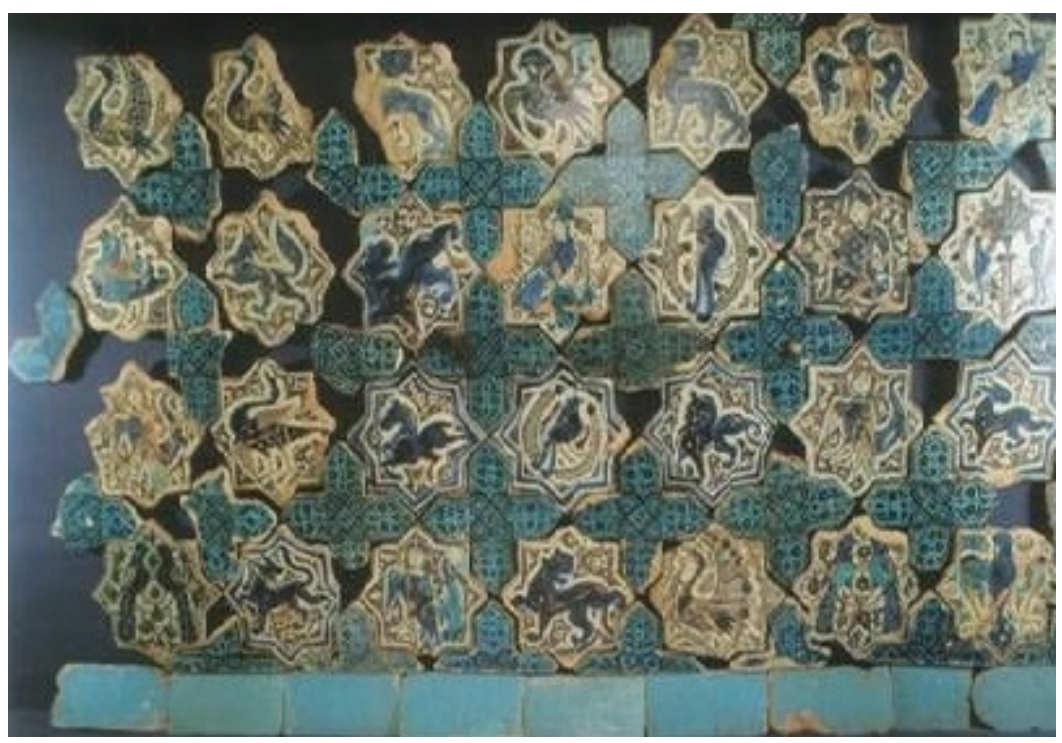

Fig. 12. Tile-work revetments from the Kubad abad Palace on display today in the Karatay Medrese, Konya, showing: "The 'kafesli' adorned walls should be so colourful, the colours of the birds in the sky should fade with envy, all laid on with turquoise and blue, so blue, the watchman of the sky should be driven into jealousy".

The turquoise and dark blue dössemeler; referring not to the floor itself but to the tiled revetments around the foot of the walls and the kafesli, explicitly meaning the cage-latticeworklike patterns of 8 pointed shamsa-star and pointed cross tile design forming the surface of these tile revetments, as is known from the excavations at this palace ${ }^{185}$, as is visible in the photograph above.

Likewise in Ibn Bibi's account of the rebuilding of the city walls of Konya and Sivas, not only did this work involve architects and master painters, with "nothing on the walls was left empty" of paintwork, "all kinds of relief work" and inscriptions including gold gilded verses of the Holy Qur'an, as was almost certainly the case for the inscriptions on the exterior of this madrasa established by the Regent in the Seljuk capital, but the construction work was conducted at speed night and day, indicating a quantity of plans and planning. It reads: "Upon that the Sultan gave orders. Those architects who knew their work and the master painters were brought. Not to lose any time, Emirs, Princes and the high born took to horse with knowledgeable architects and rode around the city... Not much later the great of the Sultanate and the notables began to build on the walls and fortifications of Konya and Sivas. All nights and days were filled with all possible effort and strength to build up the walls. With the support of God, The Almighty, great decisiveness and tenacity, a very great work was accomplished, on sound foundations the walls and towers rose up. The stones, resembling unfinished silver, were embellished with all kinds of

\footnotetext{
184 Ibn Bibi I. 363.

185 See for examples: Bozer 2008 figs. 9-11, Arık 2000 figs. 52-53, 259-260, and those examples on display in this madrasa.
} 
relief work and "temasil". Upon the soft stones and marble they wrote: gold gilded verses from the Qur'an, the Prophet's most well-known Hadith, couplets and aphorisms from the Shahname; nothing on the walls was left empty. . Therefore for long years and countless days, in order to thank those who had been connected with this work, so that their names and surname would remain, each name was inscribed on a stone (set in these walls) in gold letters" ${ }^{186}$.

Further, it is surely evident that it is quite impossible to construct designs of this complexity in cut-tile mosaic work on the curved inner surface of the dome of the Qaratā'i madrasa, with a proportional reduction in size of the shapes forming the design from the lower to the higher part of the decorative scheme employed, without any prior overall plan, designs-templates. The author writes: "Just as the stellate forms in the tile mosaic decoration of the dome grows smaller as they approach the oculus, so too, does the writing on the upper band, immediately below the oculus, diminish in size, thereby increasing the difficulty in decipherment." ${ }^{187}$, as also doubtless, the difficulty in its making. This is not a matter of making repairs to an already existing tile-mosaic surface, but rather covering this entire curved surface with a most complicated repeat pattern in cut-tile mosaic and inscription bands for the first time. The surface of the dome would have to have been marked out with great precision, and this could have been achieved through copying a prepared cartoon carrying the design. Likewise without cartoons and templates how were the ceramic inscription panels and the repeat patterns of cut-tile forms produced? Does the author think the designers and calligraphers were also the tile-cutters and mortar spreaders?

Further the author's incorporation of both the madrasa and the tomb-turba within the same suggested inscriptional program, suggesting the entire inscription program of the madrasa and turba was involved in intercession for the Regent and Emir, Jālāl al-Dīn Qaratā'ī, when these two parts are distinct in their respective functions and inscription-decoration insofar as the remains provide evidence, is a suggestion both entirely exceptional and most improbable ${ }^{188}$.

The author's earlier suggestion that there was a desire to fill, supposedly unallocated space, within the decorative program of this madrasa, cited above ${ }^{189}$, perhaps carries some trace of the erroneous Orientalist allegation of a "horror vacui", empty space being supposedly a motivating force in generating Islamic art ${ }^{190}$, is repeated in the following passage concerning the inscription bands at the foot of the dome and around the oculus carrying two Ayet from the Sürat I-baqarah, The Cow, 2:255 (The Throne Ayet) and 2:256:

"There is one addition to both of these bands that is not found in its cursive iteration below: the subsequent verse, no. 256:

There is no compulsion in religion. The right direction is henceforth distinct from error. And he who rejecteth false deities and believeth in God hath grasped a firm handhold which will never break.

I leave it to the reader to decide whether this addition can be related to the unusual

\footnotetext{
186 Ibn Bibi I. 272-273.

187 Redford 2015, 162.

188 See for example, Blair 1998, 71-73, and references therein.

189 Redford 2015, 159.

190 "This feeling of meticulously filling empty spaces also permeates Arabesque Islamic art from ancient times to the present." at https://en.wikipedia.org/wiki/Horror_vacui
} 
inclusion of a Qur'anic inscription giving voice (sic) to Solomon on the portal and of the names of David, Moses and Jesus on the interior, or whether it simply fills the added space available on the dome" ${ }^{\prime 191}$.

The reader has the task of choosing between the two options the author presents, "I leave it to the reader to decide", which seems a little odd, the reductionists' option of either/or, presented to the reader by the author, and, of course, there is no decision to be made, as both options offered by the author seem somewhat wide of the mark. What unites these names and these two Ayet of course is that they are all found in the Holy Qur'an.

The options themselves seem strange. The first option offered to the reader by the author, is that 2:256 (concerning the misrepresentation of this Ayet by the author in this chapter see the postscript) was added to $2: 255$ in these two inscription in the dome due to some implied relationship between this Ayet, Ayet 19 of Sürat 27 on the portal and the names Mūsā-Moses, Dāwūd-David and Îsa-Jesus in the interior. There is of course an association between them, in that all are mentioned in the Holy Qur'an recited by the Prophet Muhammad, but beyond this, a relationship which one would rather expect for the inscriptions on a building designed to serve as a place for the remembrance of the Almighty and a seat of Islamic education and also housing a tomb, there seems to this reviewer be no more specific relationship.

The author's second option for the reader to choose from, the 'or' option, is to suggests this Ayet was added to the preceding Ayet, to fill "the added space available on the dome", as though the author thinks that with a proportioned script such as Arabic there was any requirement due to the length of the border of the semicircle to add another Ayet, when the height of the border and the proportion of the letters can be adjusted to the space available as required. Where is "the added space available on the dome."? It is the case that this same text from Sürat I-baqarah, The Cow, 2:255 is around the iwān arch, and both 2:255 and 2:256 are employed in the wide inscription band around the foot of the dome, but also in the much smaller band around the oculus, as the author relates: "Just as the stellate forms in the tile mosaic decoration of the dome grows smaller as they approach the oculus, so too, does the writing on the upper band, immediately below the oculus, diminish in size, thereby increasing the difficulty in decipherment. However, the shapes of the letters are less distorted, and there is less knotting and interlace, leading to a quicker understanding that this band, too, reproduces the Throne Verse" ${ }^{192}$. Then there is the implicit suggestion made by the author that the content-meaning(s) of the sacred text displayed in an inscription was not of consequence, that Ayet were chosen to just fill up spaces (as likewise supposedly with the names of Prophets), based upon their length and the space available, rather than their content, that is, the meaning conveyed by these inscriptions were less important than their length. If this were the case, that texts were chosen on the basis of their length to fill a certain space, rather than their content, then looking for a meaningful link in terms of content between the Qur'anic inscriptions on a building such as the Regent and Emir Jālāl al-Dīn Qaratā'î's madrasa, and determining the inscriptional program employed, the apparent subject of this article given its title, would seem to be an exercise in futility. However, it is known that specific texts were chosen for the meaning they carry, to be placed as inscriptions in certain areas of a

\footnotetext{
191 Redford 2015, 162.

192 Redford 2015, 162.
} 
building $^{193}$, as also on specific structures, rather than selecting and employing texts from the Holy Qur'an for inscriptions on buildings primarily on the basis of their length.

The reason why there is a, "Qur'anic inscription giving voice (sic) to Solomon on the portal" is as noted above, firstly because of the prayer uttered by the Prophet and ruler SulaymānSolomon that this Ayet contains, a prayer serving in this position on the facade as the dedication for this foundation, indicating the construction of this madrasa was intended to be understood as a righteous deed, and requesting on the basis of the Almighty's mercy its founder to be numbered amongst the Almighty's righteous slaves; and also because of the longstanding recorded association of rulers of the Seljuk state with the Prophet Sulaymān-Solomon and, the Seljuk Regent and Emir Jālāl al-Dīn Qaratā'î in effect was ruler of the Sultanate as Suhayb bin Sinan ar-Rūmi had briefly been Caliph, and in part, doubtless, because of the association between the name of this prophet and marvellous works ${ }^{194}$, so marvellous that they appear to have been produced through the agency of the Jinn, such works are often marked by the 6 pointed seal, as a sign they were the work of Jinn-like master designers, naqqash, the craftsmen working to the true design for the ruler, who was often termed, "The Second Sulaymān".

The reason why the names Mūsā-Moses, Dāwūd-David and İsa-Jesus appear on the interior, together with Muhammad, who is not named by the author, is, as noted above, because these four are understood in Islam to have brought Messages from the Almighty, The Four Books,

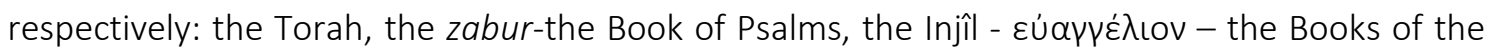
four Evangelists, and the Holy Qur'an - al-furqan.

A reason why Ayet 256 of Sürat I-baqarah, The Cow, is given, together with Ayet 255, is not simply because one follows the other in the text of the Holy Qur'an, but because the former relates the Absoluteness of the Almighty and the subsequent Ayet relates the guidance given to that which is dependent upon the Almighty and relates the connection between that which is on the Throne to that which is beneath it, stating, "Allah is Hearer, Knower." and indicating thereby the means whereby human beings can complete this connection, "And he who rejecteth false deities and believeth in Allah hath grasped a firm handhold which will never break." And it therefore seems to have been the case that the choice made to use these two Ayet recorded in these two inscriptions in the dome was to define and link the entire area beneath the dome to its apex and to the light coming through the oculus, representing the Light of the Absolute.

In consequence of the above, the author's two proffered options: "I leave it to the reader to decide whether this addition can be related to the unusual inclusion of a Qur'anic inscription giving voice (sic) to Solomon on the portal and of the names of David, Moses and Jesus on the interior, or whether it simply fills the added space available on the dome."195, can both be discarded.

Postscript: A question of academic due diligence and scholarly ethics

In chapter 7 in this book, on page 162 one reads: "There is one addition to both of these bands that is not found in its cursive iteration below: the subsequent verse, no. 256:

There is no compulsion in religion. The right direction is henceforth distinct from error. And he who rejecteth false deities and believeth in God hath grasped a firm handhold which will never

\footnotetext{
193 For examples of particular inscriptions on particular building types, see for example: Blair 1998, 68-75.

194 Holy Qur'an Sūrat Al-'Anbyā' 82; Sūrat Saba' 12-13.

195 Redford 2015, 162.
} 


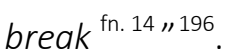

The author presents the reader with what is stated to be, 'the subsequent verse, no. 256:' and which appears at first sight to be a translation of Surrat 2:256. The reader then turns to the footnote 14 given for this quotation and reads:

fn. 14 "Mohammed Marmaduke Picthall (trans.), The Meaning of the Glorious Koran (New York: Mentor, n.d.). I modified this translation only by substituting 'God' for 'Allāh'"'197.

No reason is given for this modification to the translation. The wisdom of the substitution made is debateable, given that the name Allāh is not unknown to the literate in English and was given to humanity in a Revelation subsequent to the Christian one, and altering or modifying sacred texts in published translation without providing reason(s) is somewhat problematic. One rather wonders what would be said for example if in a republication of verses from the New Testament in English in 2015 the word 'God' was removed without reasons being given, and was replaced by the word, 'Yahweh'?

Perhaps more importantly, in the statement presented in this footnote the author seems to deliberately mislead the reader. Not only did the author substitute the word 'God' for 'Allāh' as is noted, but also completely lost from the published translation the entire last sentence of this Ayet, 2: 256: 22-24.

A possible indication of some such was provided by the use of the word, 'only' in the footnote, as one would expect to read: "I have modified this translation by substituting 'God' for 'Allah'.", hopefully also providing some reasons for this unilateral intervention, rather than, "I modified this translation only by substituting 'God' for 'Allah'." The loss-removal of a sentence from this Ayet, without informing the reader and, it seems, deliberately and wilfully misleading the reader as to the contents of this Ayet, tampering with the text, was presumably done to serve some argument being made by the author. Deliberately misleading because the author clearly states: I modified this translation only by substituting 'God' for 'Allah', with no reason given for this substitution and without mentioning the deletion of an entire sentence.

The Arabic text of Sūrat 2:256 is:

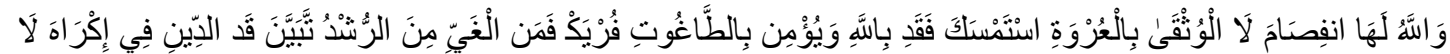

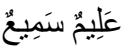

Mohammed Marmaduke Picthall's translation of Sūrat 2:256 reads:

"There is no compulsion in religion. The right direction is henceforth distinct from error. And he who rejecteth false deities and believeth in Allah hath grasped a firm handhold which will never break. Allah is Hearer, Knower" ${ }^{198}$.

The author of this chapter has a different, edited text, while recording it as being Mohammed Marmaduke Picthall's translation of Sürat 2:256 with the record of the substitution of 'God' for Allāh, made five pages later in the notes:

"There is no compulsion in religion. The right direction is henceforth distinct from

\footnotetext{
196 Redford 2015, 162.

197 Redford 2015, 168.

198 Available at this soruce: http://corpus.quran.com/translation.jsp?chapter=2\&verse $=256$
} 
error. And he who rejecteth false deities and believeth in God hath grasped a firm handhold which will never break"199.

What the author cites as Mohammed Marmaduke Picthall's translation of Sūrat 2:256 is not Mohammed Marmaduke Picthall's translation of Sūrat 2:256. What is presented to the reader of this translation in Chapter 7 of this academic work is in fact, an edited, truncated and so falsified version of Mohammed Marmaduke Picthall's translation of The Glorious Qur'ân. Missing from the published text of this Ayet are the Names of the Almighty: Allāh, once replaced by the word God, and then: "Allāh, The Hearer, (The) Knower" lost from this Ayet.

One rather wonders how an academic mind decides to edit and alter a well-known translation of a sacred text, without informing the reader of the full extent of the excisions and changes made, and why? One may also wonder why the text was not checked, including the text of the Qur'an citations. It appears nobody bothered to read the proofs, because otherwise, if the text had been read carefully, certainly the missing passage describing the relationship between Neo-Platonism and the decoration in this madrasa, mentioned by the author in the conclusion, would have been noticed, as well as the missing Names of Allāh. Unfortunately, reading Chapter 7 of this edited book, published by the Cambridge University Press in 2015, raises the question of academic diligence and scholarly ethics, or rather, provides a somewhat unfortunate example of the lack of them.

Figure Sources:

Fig.1. http://admin.gateofturkey.com/api/data/GetHeader/mage/3856/malatya\%20ulu\%20cami i\%20kubbesi-malatya.jpg

Fig. 2-10. TMP Duggan.

Fig. 11. http://dome.mit.edu/bitstream/handle/1721.3/65428/157225_sv.jpg?sequence $=2$

Fig. 12. yazarkafe.hurriyet.com.tr\%2FDetail\%2F552539\%2Fanadolu-selcuklu-cinileri\&psig=AFQjC NH4aV9n4fOBnqdc

199 Redford 2015, 162. 


\section{BIBLIOGRAPHY}

\section{Sources}

Abdul-Rahman 2009

M. S. Abdul-Rahman, Tafsir Ibn Kathir Juz' 5 (Part 5): An-Nisaa 24 to AnNisaa 147. London 2009.

Aflaki Manaqeb al-arefin

Shams al-Din Ahmad-e Aflaki, The Feats of the Knowers of God (Manaqeb al-arefin). Trans.: J. O’Kane. Leiden 2002.

al-Makkī Qūt al-qulūb al-Makkī, Die Nahrung der Herzen: Abū Ṭālib al-Makkīs Qūt al-qulūb, vols. I-IV. Trans.: R. Gramlich. Stuttgart 1992-1995.

er-Ravendi

M. b. Ali b. Süleyman er-Ravendi, Rahat-üs-Sudur ve Ayet-üs Sürur, vol. II. Çev.: A. Ateş. Ankara 1999.

Ibn Arabi 2000 Ibn Arabi, Harflerin IImi. Çev.: M. Kanık. Bursa 2000.

Ibn Arabi Fusus al-Hikam Ibn Arabi, The Wisdom of the Prophets (Fusus al-Hikam). Trans.: A. CulmeSeymour. Gloucestershire 1975.

Ibn Bibi Ibn Bibi El-Hüseyin b. Muhammed b. Ali El-Ca'feri Er-Rugadi, El Evamirü'l-Ale'iye Fi'L-Umuri'l-Ala'iye, (Selçukname: 2 Volumes). Çev.: M. Öztürk. Ankara 1996.

Ibn Ishaq Al-sira al-Nabawiyya Ibn Ishaq, The Life of Muhammad: Apostle of Allah. Ed. M. Edwardes. London 1964.

Jālāl al-Dīn Rūmī Dîvâni Shemsi Tabrîzi

Mawlana Jālāl al-Dīn Rūmī, Selected Poems from the Divani Shemsi Tabriz. Trans.: R. A. Nicholson. Cambridge 1977.

Jālāl al-Dīn Rūmī Fîhi Mâ Fîhi Mawlana Jālāl al-Dīn Rūmī, Discourses of Rūmī. Trans.: A. J. Arberry. New York 1977.

Jālāl al-Dīn Rūmī Mathnawi Mawlana Jālāl al-Dīn Rūmī, The Mathnawi of Jalalud'din Rumi, vols. I-VI. Trans.: R. A. Nicholson. Cambridge 1982.

Kitâb al- Hadâyâ wa al-Tuhaf The Book of Gifts and Rarities - Kitāb al-Hadāyā wa al-Tuhaf. Ed. \& Trans.: Ghāda al Hijjāwi al Qaddūmī. Cambridge 1996.

Nizâmî-i Gencevi Haft Paikar Ilyas Abu Muhammad Nizâmî-i Gencevi, The Haft Paikar by Nizami of Ganja, Trans. and Commentary, vol. I. Trans.: C. E. Wilson. London 1924.

\section{Modern Literature}

Ad-Daghistani 1982

A. Ad-Daghistani, The Naqshbandi Way: A Guidebook For Spiritual Progress. Trans.: N. A. Al-Qubrusi. Konya 1982.

Addas 1993

C. Addas, Quest for the Red Sulphur: The Life of Ibn 'Arabī. Cambridge 1993.

Arık - Arık 2008

R. Arık - O. Arık, Tiles Treasures of Anatolian Soil: Tiles of the Seljuk and Beylik Periods. İstanbul 2008.

Arık 2000

R. Arık, Kubad Abad. İstanbul 2000.

Blair 1998

S. S. Blair, Islamic Inscriptions. New York 1998.

Boyle 1997

Bozer 2008

J. A. Boyle, Genghis Khan: The History of the World Conqueror by 'AtaMalik Juvaini, Trans. From the Text of Mizra Muhammad Qazvin. Manchester 1997.

R. Bozer, "Forms of Seljuk Tile Panels, Observations on the Designs of Wall Coverings and some Processes after Glazing". Eds.: R. Ank - O. Arık, Tiles, Treasures of Anatolian Soil: Tiles of the Seljuk and Beylik Periods. İstanbul (2008) 191-207.

Brown 1968

J. P. Brown, The Darvishes or Oriental Spiritualism. London 1968.

Burckhardt 2001

2001. 
Cahen 2001

Chittick 1983

Duggan 2009

Duggan 2014

Duggan 2016a

Duggan 2016b

Elliot 2006

Ephrat 2011

Ernst 1994

Hillenbrand 2011

Lindsay 1994

Mahdi 2001

Morewedge 1992

Netton 1991

Öney 1992

Picthall 1998

Redford 1996

Redford 2007

Redford 2010

Redford 2015

Renard 2004

Ruggles 2011
C. Cahen, The Formation of Turkey: The Seljukid Sultanate of Rum: Eleventh to Fourteenth Century. Ed. \& Trans.: P. M. Holt. Harlow-Essex 2001.

W. C. Chittick, The Sufi Path of Love: The Spiritual Teachings of Rumi. Albany N.Y. 1983.

T. M. P. Duggan, "Diplomatic Shock and Awe: Moving, Sometimes Speaking Islamic Statues". Al-Masaq: Journal of the Medieval Mediterranean 21/3 (2009) 229-267.

T. M. P. Duggan, "Veil of Light - Işığın Örtüsü". MJH IV/1 (2014) 129-157.

T. M. P. Duggan, "Not Just the Shadows on the Stone: the Greek, Lycian

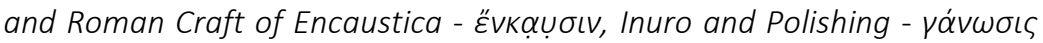

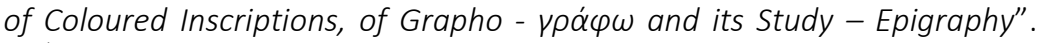
$19^{\text {th }}$ Symposium On Mediterranean Archaeology: Time Space And People Proceedings 2016 [forthcoming].

T. M. P. Duggan, "Zigzag - The Flash of Light in the Polished Mirror - the Design and a Reminder of the Light of the Almighty-nür-i Ilāhi". 2016 [forthcoming].

J. Elliot, Mirrors of the Unseen: Journeys in Iran. London 2006.

D. Ephrat, "The Seljuqs and the Public Sphere in the Period of Sunni Revivalism: The View From Baghdad". Eds. C. R. Lange - S. Mecit, The Seljuqs: Politics, Society and Culture. Edinburgh (2011) 139-156.

C. W. Ernst, Words of Ecstasy in Sufism. Kuala Lumpur 1994.

C. Hillenbrand, "Aspects of the Court of the Great Seljuqs". Eds.: C. R. Lange - S. Mecit, The Seljuqs: Politics, Society and Culture. Edinburgh (2011) 22-38.

J. E. Lindsay, Professors, Prophets, and Politicians: 'Ali Ibn 'Askir's Ta'rikh Madinat Dimashq. Published PhD Thesis, University of WisconsinMadison. Wisconsin 1994.

M. Mahdi, Alfarabi: Philosophy of Plato and Aristotle. New York 2001.

P. Morewedge, "The Neoplatonic Structure of some Islamic Mystical Doctrines". Ed.: P. Morewedge, Neoplatonism and Islamic Thought. Albany (1992) 51-74.

I. R. Netton, Muslim Neoplatonists: An Introduction to the Thought of the Brethren of Purity. Edinburgh 1991.

G. Öney, Anadolu Selçuklu Mimari Süslemesi ve El Sanatları. İstanbul 1992. M. M. Picthall, The Meaning of The Glorious Qur'ân: An Explanatory Translation. İstanbul 1998.

S. Redford, "Seljuk Pavilions and Enclosures in and around Alanya". AST XIV/1 (1996) 453-464.

S. Redford, "The Kıble Wall of the Kargı Hanı". Adalya X (2007) 351-367.

S. Redford, "Some Problems of Anatolian Seljuk Inscriptions from Antalya and Alanya". Eds.: S. Doğan - M. Kadiroğlu, Bizans ve Çevre Kültürler: Yıldız Ötüken Armağanı. İstanbul (2010) 304-310.

S. Redford, "Intercession and Succession, Enlightenment and Reflection: the Inscriptional and Decorative Program of the Qaratay Madrasa, Konya". Ed.: A. Eastmond, Viewing Inscriptions in the Late Antique and Medieval World. Cambridge (2015) 148-169.

J. Renard, Knowledge of God in Classical Sufism: foundations of Islamic Mystical Theology. New York - Mahwah NJ. 2004.

Islamic Art \& Visual Culture - An Anthology of Sources. Ed.: D. F. Ruggles. 
Schimmel 1978

Schimmel 1984

Schimmel 2001

Shah 1975

Sönmez 1989

Shushud 1983

Tabbaa 2001

Talmon-Heller 2007

Ter Haar 1999

Turan 1948

Türkmen 2009

Walbridge 1999

Yakıt 1992

Oxford 2011.

A. Schimmel, Mystical Dimensions of Islam. Chapel Hill 1978.

A. Schimmel, Calligraphy and Islamic Culture. London - New York 1984.

A. Schimmel, As Through a Veil: Mystical Poetry in Islam. Oxford 2001.

I. Shah, The Pleasantries of the Incredible Mulla Nasrudin. London 1975.

Z. Sönmez, Başlangıcından 16. Yüzyıla Kadar Anadolu Türk-Islam Mimarisinde Sanatçılar. Ankara 1989.

H. Shushud, Masters of Wisdom of Central Asia. Oxford 1983.

Y. Tabbaa, The Transformation of Islamic Art during the Sunni Revival. London - New York 2001.

D. Talmon-Heller, Islamic Piety in Medieval Syria. Mosques, Cemeteries and Sermons under the Zangids and Ayyubids (1146-1260). Leiden 2007.

J. G. J. Ter Haar, "The Spiritual Guide in the Naqshbandī Order". Ed.: L. Lewisohn, The Heritage of Sufism: The Legacy of Medieval Persian Sufism (1150-1500). London (1999) 311-321.

O. Turan, "Celaleddin Karatay, Vakıflar ve Vakfiyeleri". Belleten XII/45 (1948) 16-160

E. Türkmen, Teachings of Shams-i Tabrezi (Rumi's Master). Konya 2009.

J. T. Walbridge, "A Sufi Scientist of the Thirteenth Century: The Mystical Ideas and Practices of Qubt al-Din Shirazi". Ed.: L. Lewisohn, The Heritage of Sufism, Volume II: The Legacy of Medieval Persian Sufism (1150-1500). Oxford (1999) 323-341.

i. Yakıt, Türk-İslam Kültüründe EBCED Hesabı ve Tarih Düşürme. İstanbul 1992.

\section{Online Sources}

http://www.estanbul.com/esma-ul-husnanin-3lu-vefkleri-21639.html\#.VLwUXnurHNg

http://www.medievalhistories.com/viewing-inscriptions-in-the-late-antique-and-medieval-world/

http://www.islamic-awareness.org/Quran/Tafseer/daarimi.html

http://www.java-man.com/pages/books/alhisba.htmI\#GREED IS THE CAUSE OF SLIPPING INTO DEVIATION (accessed 8-01-2016)

http://www.qtafsir.com/index.php?option=com_content\&task=view\&id=1297

http://corpus.quran.com/translation.jsp?chapter=2\&verse $=256$

https://ilookilisten.wordpress.com/2014/04/02/the-story-of-suhaib-ibn-sinaan-ar-rumi-radiallahu-anhuhadith-no-1917/

http://admin.gateofturkey.com/api/data/GetHeaderlmage/3856/malatya\%20ulu\%20camii\%20kubbesimalatya.jpg

http://media-cdn.tripadvisor.com/media/photo-s/03/4b/da/9c/karatay-medresesi-museum.jpg http://dome.mit.edu/bitstream/handle/1721.3/65428/157225_sv.jpg?sequence=2 